Research paper

\title{
The South American retroarc foreland system: The development of the Bauru Basin in the back-bulge province
}

\author{
Mirian Costa Menegazzo ${ }^{\text {a, }}$, Octavian Catuneanu ${ }^{b}$, Hung Kiang Chang ${ }^{c}$ \\ a Universidade Petrobras, Petróleo Brasileiro S.A. - Petrobras, rua Júlio do Carmo, 323, Rio de Janeiro, Rio de Janeiro, 20211-160, Brazil \\ ${ }^{\mathrm{b}}$ Department of Earth and Atmospheric Sciences, University of Alberta, 1-26 Earth Sciences Building, Edmonton, Alberta, T6G 2E3, Canada \\ ${ }^{c}$ Laboratório de Estudos de Bacias, Universidade Estadual Paulista, Avenida 24-A, 1515, Rio Claro, São Paulo, 13506-900, Brazil
}

\section{A R T I C L E I N F O}

\section{Article history:}

Received 16 October 2015

Received in revised form 21 February 2016

Accepted 23 February 2016

Available online 27 February 2016

\section{Keywords:}

Andean orogeny

Back-bulge

Late Cretaceous

Retroarc foreland system

Subsidence mechanisms

\begin{abstract}
A B S T R A C T
The aim of this research is to understand the tectonic setting of the Bauru Basin. This basin in centraleastern South America has been classified as intracratonic, but the basin-fill geometry, the involved subsidence mechanisms and the age of the deposits are poorly understood. In this work, the ranges of the fossil taxa are analyzed and ages are proposed for the lithostratigraphic units. Isopach maps were used to reconstruct the stratigraphic intervals of the basin fill. The stratigraphy of the Bauru Basin is compared with that of the adjacent basins, and the data are integrated with the available information on South American geodynamics. The fossil record indicates that sediment accumulated from the Cenomanian to early Paleocene, beginning after the Mochica Phase of the Andean orogeny. The basin-fill geometry demonstrates migration of the depocenter through time, which occurred simultaneously with migration of the Andean Basin and immediately after the orogenic events of the Peruvian Phase. We propose that the Bauru Basin is a component of a retroarc foreland system developed during the early stages of the Andean evolution and that it was developed in the back-bulge province of this system. The Andean Basin constitutes the foredeep depozone of this foreland system (including the Potosí, Oriente, Acre and Marañon basins). In addition, the Upper Cretaceous of the Parecis and Solimões basins were likely also developed in the back-bulge province. The thickness of the Bauru accumulation indicates that other mechanisms might have overlapped the flexural subsidence in this back-bulge province.
\end{abstract}

() 2016 Elsevier Ltd. All rights reserved.

\section{Introduction}

Classification of sedimentary basins situated in intraplate settings far from plate boundaries is not obvious, as in certain other tectonic settings. To describe these basins as "intracratonics" is an oversimplification, especially if the subsidence mechanisms are not completely clear. The Bauru Basin in central-eastern South America is a case in point (Fig. 1). This basin has been classified as intracratonic, but its origin and stratigraphy can be explained with reference to plate-margin processes, and therefore, it is not intracratonic in a tectonic sense.

The Bauru Basin covers an area of approximately $379.362 \mathrm{~km}^{2}$ located almost exclusively in Brazil (Figs. 1 and 2), with selected outcrops in Northeastern Paraguay (Fúlfaro, 1996). This Cretaceous

\footnotetext{
* Corresponding author.

E-mail addresses: miriancm@gmail.com (M.C. Menegazzo), octavian@ualberta. ca (O. Catuneanu), chang@rc.unesp.br (H.K. Chang).
}

sedimentary succession reflects changing nonmarine environments, such as eolian, lacustrine, fluvial and alluvial fans.

The aim of this research is to analyze the mechanisms responsible for creation and development of the Bauru Basin. The stratigraphic range of its paleobiota is examined in detail, accompanied by age determinations of the lithostratigraphic units. The current work improves the understanding of large-scale stratigraphic patterns, subsidence mechanisms, the role of tectonics in control of the overall geometry of the Bauru basin-fill, and the geodynamics of the South American Plate and also makes comparisons between the Bauru Basin and other Cretaceous basins in South America. Isopach maps were constructed using published well log information (SIAGAS, n.d.; Sallun Filho et al., 2009) and unpublished data provided by DAEE (Departamento de Águas e Energia Elétrica, São Paulo State Government), which were, both calibrated with cores. These isopach maps illustrate the basin-fill geometry and the migration of its depocenter through time.

A deeper understanding of the tectonic setting and sedimentation controls of the Bauru Basin supports the construction of 


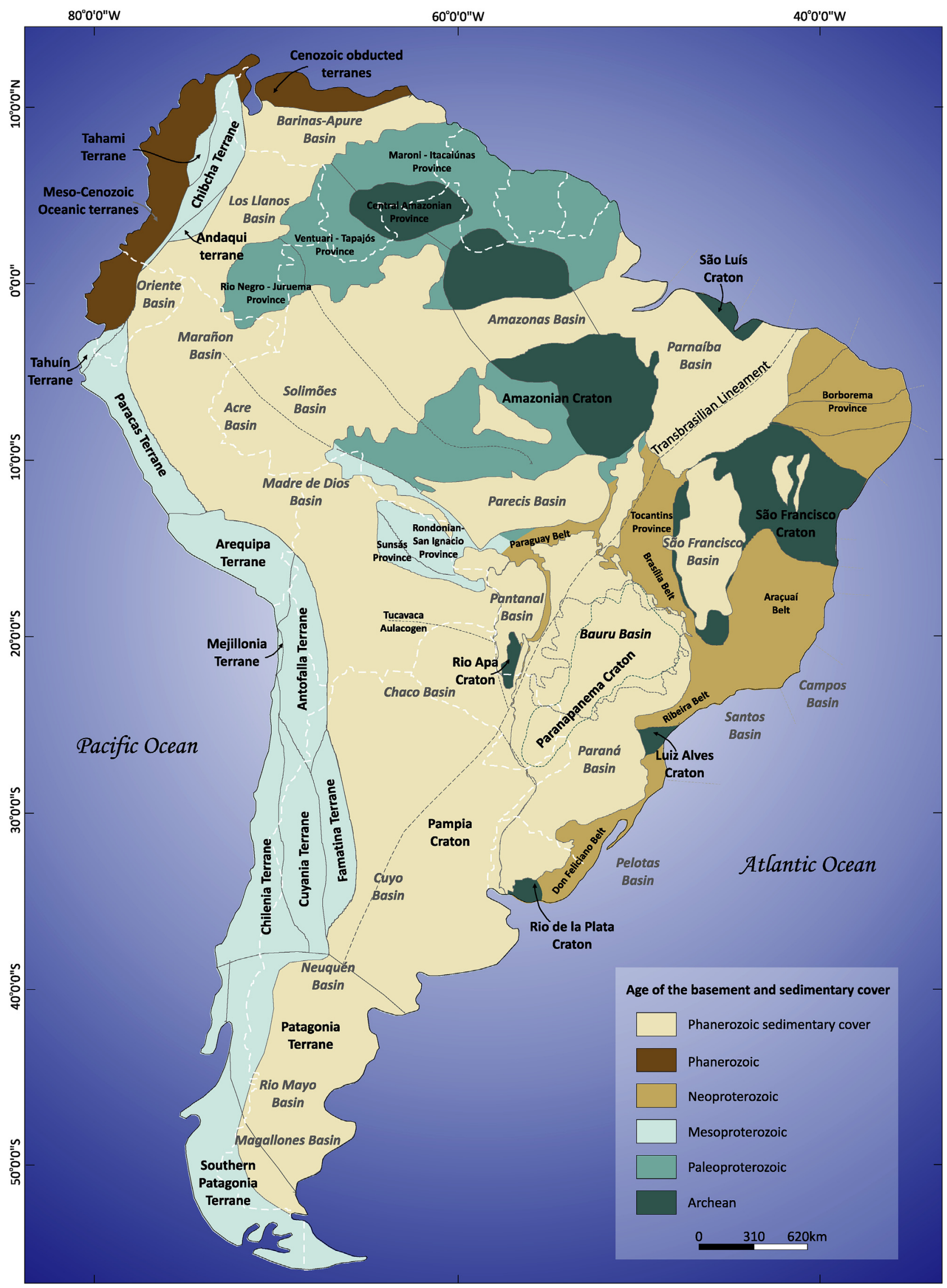

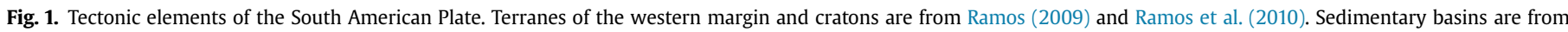

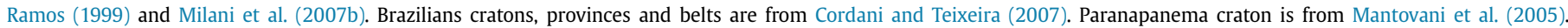
Transbrasilian Lineament is adapted from Cordani and Teixeira (2007), Ramos et al. (2010) and Curto et al. (2014). 
stratigraphic models that might improve characterization and exploitation of the Bauru aquifer, which is located in one of the most populous regions of Brazil. In addition, the models will support biogeographic and evolutionary studies of its paleobiota. The Bauru Basin analysis aggregates information to understand the South American geodynamics in the Late Cretaceous and the development of several contemporaneous basins, which might be useful for predicting the presence of key elements of petroleum systems in frontier basins and could provide a model of investigation for similar older basins in South America.

\subsection{Geological background and tectonic setting}

From the Late Triassic to Early Cretaceous, an extensional regime prevailed in the South American Plate related to the Gondwana breakup and opening of the South Atlantic Ocean (Mégard, 1984; Sempere et al., 1997; Zerfass et al., 2004, 2005; Ramos, 2009; Bockhout et al., 2012). After the breakup in the Pelotas and Santos basins, in the late Early Cretaceous (Chang et al., 1992; Zalán and Oliveira, 2005; Moreira et al., 2007; Stica et al., 2014), the South American Plate changed the absolute motion to the west increasing the convergence rate with the Farallon Plate (Ramos, 1999, 2009; Ramos and Alemán, 2000; Maloney et al., 2013); and the stress regime in South America changed from extensional to compressional (Chang and Kowsmann, 1996; Riccomini et al., 2005; Ramos, 2009, 2010; Folguera et al., 2011). Therefore, the western margin of South America was first subjected to compression and began uplift of the early Andean orogen (Mégard, 1984; Jaillard and Soler, 1996; Jaillard et al., 2000; Ramos, 2009, 2010; Folguera et al., 2011; Vásquez and Altenberger, 2005; Maloney et al., 2013; Pfiffner and Gonzalez, 2013; Fennel et al., 2015). Consequently, in the early Late Cretaceous, a series of foreland basins developed parallel to the Andean thrust front, with the Andean Basin in the northern and central regions of the Central Andes (Jaillard and Sempere, 1991; Rouchy et al., 1993; Martinez and Mamani, 1995; Sempere et al., 1997; Jaillard et al., 2000; Mpodozis et al., 2005; Fennel et al., 2015).

In the interior continent, Late Cretaceous successions were deposited over Paleozoic basins parallel to the Andean Basin. The Bauru Basin, which is the focus of this study, is superimposed on the northern Paraná Basin and primarily overlaps the volcanic rocks of the Serra Geral Formation (Fig. 1). In this area, is the crustal thickness averages $40 \mathrm{~km}$ (Assumpção et al., 2013; van der Meijde et al., 2013; Mariani et al., 2013) with high flexural rigidity (Peréz-Gussinté et al., 2007) and is largely of the Paleoproterozoic Paranapanema Craton (Mantovani et al., 2005; Ramos et al., 2010).

The mechanisms responsible for the Bauru Basin subsidence are controversial. It has been argued that reactivation of tectonic elements of the basement resulted in an extensional sag as a consequence of opening of the South Atlantic Ocean, westward migration of the South American Plate and its interaction with adjacent plates (Fernandes and Coimbra, 1992; Fúlfaro and Perinotto, 1996; Paula e Silva et al., 2009). Suguio et al. (1977) and Fúlfaro and Barcelos (1993) proposed grabens and horsts. Certain authors noted load and thermal subsidence related to cooling of the subjacent volcanic rocks (Zalán et al., 1990; Fernandes and Coimbra, 1996, 2000; Riccomini, 1997b; Milani, 2003; Milani et al., 1994, 2007; Milani and De Wit, 2008; Fernandes and Ribeiro, 2015). From the point of view of Chang and Kowsmann (1996), the region of the Bauru deposits were downwarped by the action of intraplate stresses related to the inversion of the South American stress regime. Mariani et al. (2013) suggested that crustal overloading and cooling of magmatic underplating generated the accommodation for the Bauru deposits.

The subjacent Paraná Basin was developed from the Ordovician to Early Cretaceous (Milani et al., 1994, 2003), and its sedimentation has been associated with cycles of terrane accretions in the preAndean margin of the Gondwana (Zalán et al., 1990; Milani et al., 1994, 2003; Milani et al., 2007; Catuneanu et al., 1998). The Paraná Basin resulted from flexural foreland and intracratonic subsidence mechanisms (Milani and De Wit, 2008) and can be understood in terms of different basins superposed in time and space (Zalán et al., 1990) or a sedimentary pack subdivided into sequences related to different subsidence mechanisms (Milani et al., 1994, Milani, 2003; Milani et al., 2007). In this context, the Bauru deposits have been classified as a sequence of the Paraná Basin (Soares et al., 1980; Zalán et al., 1990; Chang and Kowsmann, 1996; Milani, 2003; Milani et al., 1994, 2007; Milani and De Wit, 2008; Paula e Silva et al., 2009) or assumed as a distinct tectonic unit (Fernandes and Coimbra, 1992; Fúlfaro and Perinotto, 1996; Fernandes and Coimbra, 1996, 2000; Riccomini, 1997b).

There is a lack of consensus on the beginning of the sedimentation in the Bauru Basin and the age of each lithostratigraphic unit, which have been precluded correlations with other basins and geodynamic events. Soares et al. (1980) attributed Aptian age to the Caiuá and Santo Anastácio formations, Cenomanian-Santonian to the Adamantina Formation, and Santonian-Maastrichtian to the Marília Formation. The palynological studies of Lima et al. (1986) established certain mudstones strata as Coniacian, and posteriorly, these strata were assumed as the Araçatuba Formation. Gobbo-Rodrigues et al. (1999a, 1999b) stated that the Adamantina and Araçatuba formations are Campanian-Maastrichtian and the Marília Formation is Maastrichtian, considering the record of ostracods and charophytes. Santucci and Bertini (2001) indicated Campanian-Maastrichtian for the Adamantina and Marília formations, in view of the Sauropodomorpha record. Dias-Brito et al. (2001) noted Turonian-Santonian for the Adamantina Formation (not discriminated from the Araçatuba Formation), and Maastrichtian age for the Marília Formation by focusing on ostracods and charophytes. Furthermore, Dias-Brito et al. (2001) estimated an Aptian-Cenomanian age for the Caiuá and Santo Anastácio formations, and Coniacian-Santonian for the Uberaba Formation, considering their stratigraphic positions.

Certain recent fossil discoveries, not only in Bauru but also in other basins, have brought new elements to the discussion of the age of the Bauru Basin. In addition, the detailed geological mapping realized in the 1990s and the latest lithostratigraphical studies of the Bauru Basin (e.g. Fernandes and Coimbra, 1996, 2000; Paula e Silva et al., 1994, 2009) resulted in redefinition of a subset of the Bauru Basin fossil localities. Herein, the detailed exam of the biostratigraphic information reveals that these new discoveries extend the temporal range of selected taxa, consequently clarifying the age of the sedimentation, and indicate ages of units previously thought to be without fossils.

The definition of the ages of the events of creation of accommodation space in the Bauru Basin, allowed the establishment of correlations with other basins and coeval geodynamic events. Then, we propose that the Bauru basin-fill corresponds to a first order sequence, that is, the product of sedimentation within a particular tectonic setting. This tectonic setting conditioned the development of a new basin in an area that presents older sedimentary deposits of distinct nature. Therefore, this unit is herein viewed as a basin.

\section{Bauru Basin}

\subsection{Lithostratigraphy}

Although a large discrepancy exists between the current lithostratigraphic proposals for the Bauru Basin (Soares et al., 1980; Barcelos et al., 1983; Fúlfaro and Perinotto, 1996; Fernandes and Coimbra, 2000; Paula e Silva et al., 2005, 2009; Fernandes and 


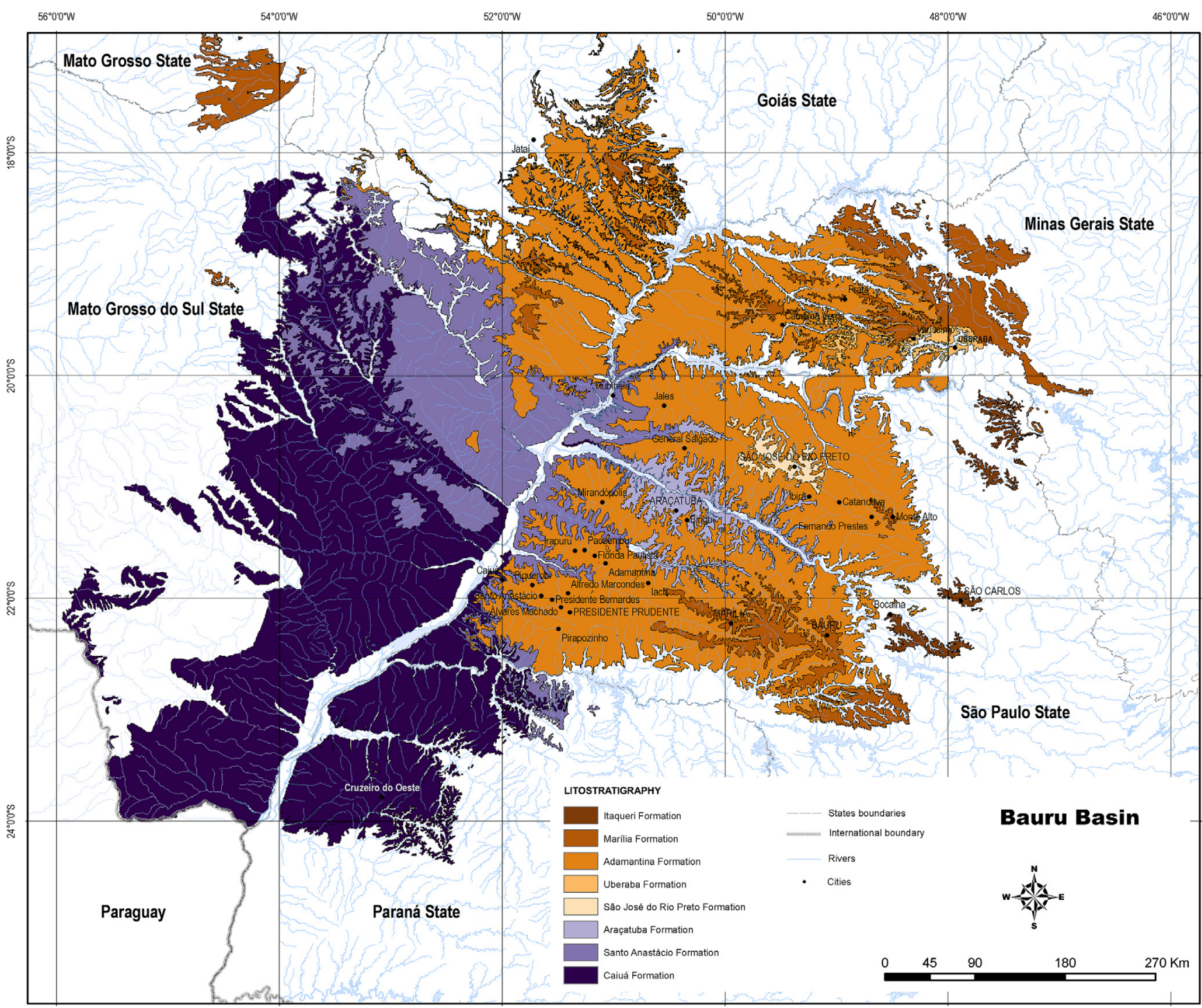

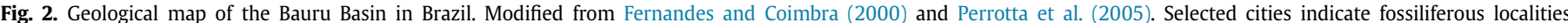
discriminated in Supplementary Material.

Ribeiro, 2015), this succession can be characterized by ten units, namely, the Caiuá, Pirapozinho, Araçatuba, Santo Anastácio, Birigui, São José do Rio Preto, Uberaba, Adamantina, Marília and Itaqueri formations (Fig. 2).

The Caiua and Pirapozinho formations represent the base of the basin. The Pirapozinho Formation partially overlays the Caiuá Formation, and both are superimposed on the Serra Geral Formation. The Caiuá Formation consists of well-sorted and well-rounded sandstones, with large-scale cross-bedded sets. The cross-beds commonly show coarse layers with reverse and normal grading alternating with finer beds. Additionally present are fining-upward cycles with intraformational conglomerates, fine to medium sandstones with cross-stratification or ripples, and mudstone layers. These deposits have been interpreted as eolian (Soares et al., 1980) and fluvial (Paula e Silva et al., 2005, 2009). According to Fernandes and Coimbra (2000), this unit can be subdivided into the Goio Erê and Rio Paraná formations, which is not adopted in this research because was not found distinction between these deposits. As reported by Fúlfaro (1996) and Fariña (2009), the Acaray Formation is the equivalent of the Caiuá Formation in Paraguay.

The lower portion of the Pirapozinho Formation is composed of massive and thinly laminated mudstones interbedded with thin notably fine sandstone strata with ripple cross-lamination. Multiple coarsening-upward cycles of mudstones to rippled fine sandstones predominate in the upper portion, but fine to medium sandstones with planar-to trough-cross stratification also occur as well as conglomerates with intraclasts of mudstones. Bioturbation and root marks are frequent. These deposits result from lacustrine and fluvial depositional environments (Paula e Silva et al., 2005, 2009).

The Santo Anastácio, Araçatuba and Birigui formations occur in an intermediate position. The Santo Anastácio Formation overlies the units below, including the Serra Geral Formation. The Araçatuba Formation partially covers the Santo Anastácio Formation and is in contact with the basalts of the Serra Geral Formation, the basement of the basin. The Birigui Formation is interdigitated with the Araçatuba, and in certain well logs, the Birigui Formation appears above the Santo Anastácio Formation.

The Santo Anastácio Formation consists of amalgamated fine to medium sandstones beds and can be massive or display planar cross-stratification. Certain beds have primary stratifications that are obscured or destroyed, with a mottled appearance. Carbonate nodules and root marks are quite common. From the point of view 
of Fernandes and Coimbra (2000), these deposits correspond to sand sheets in marginal deserts plains. Soares et al. (1980) and Paula e Silva et al. (2009) noted a braided fluvial depositional environment. In addition, Fúlfaro et al. (1999) emphasized the occurrence of paleosols.

The Araçatuba Formation is primarily composed of massive and laminated mudstones, with notably small carbonates nodules. Secondarily, very fine to fine sandstones occur with tabular stratification and ripple cross-lamination, wave ripples, heterolithic facies (flaser, lenticular and wavy bedding), mudcracks and eventually micro-hummocky lenses. Ichnofossils and small root marks are frequent. The Araçatuba Formation has been interpreted as lacustrine deposits (Fernandes and Coimbra, 2000; Batezelli et al., 2003; Paula e Silva et al., 2009; Fernandes and Ribeiro, 2015).

The Birigui Formation is composed of fine to medium sandstones with trough and planar-cross stratifications or ripple crosslamination and heterolithic intervals with thickening-upward patterns. Ichnofossils, root marks and mudcracks are also present. This formation is interpreted as deposits of a braided fluvial system (Paula e Silva et al., 2009).

Finally, the upper portion of the Bauru Basin corresponds to the Adamantina, São José do Rio Preto, Uberaba, Marília and Itaqueri formations. The Adamantina Formation overlies the Santo Anastácio and Araçatuba formations, extends over the basalts of the Serra Geral Formation on the North and East of the basin, and laterally contacts the São José do Rio Preto and Uberaba formations. The São José do Rio Preto is superimposed on the Santo Anastácio Formation, whereas the Uberaba Formation occurs in a restricted area covering the Serra Geral Formation (Fig. 2). The Marília Formation overlies the Adamantina and Uberaba Formations, and the Itaqueri Formation on the eastern area of the basin covers the Serra Geral and Botucatu formations and is partially in contact with the Marília Formation.

The Adamantina Formation is characterized as fine sandstones with ripple cross-lamination or planar-to trough-cross stratification, eventually with intraclasts of mudstones at the base of the troughs, interbedded with heterolithic facies, mudstones with mudcracks, root marks and ichnofossils, and matrix-supported intraformational conglomerates. According to Soares et al. (1980) and Paula e Silva et al. (2009), these deposits resulted from a meandering fluvial depositional environment. From the point of view of Fernandes and Coimbra (2000), the Adamantina Formation can be partitioned into the Vale do Rio do Peixe, Presidente Prudente and São José do Rio Preto formations, the former resulting from eolian deposition and the others from fluvial environments. The São José do Rio Preto Formation has distinctive characteristics, making it easy to differentiate it from the Adamantina Formation. However, the Presidente Prudente and Vale do Rio do Peixe formations are not easily distinguished, and these designations are not adopted in this research.

The São José do Rio Preto Formation consists of very fine to medium sandstones with planar-to trough-cross stratification as well as ripple cross-lamination and cross-bedded intraformational conglomerates, which are massive or show grading of clasts and/or matrix. The conglomerates are rather frequent, varying from clastsupported to matrix-supported, eventually with angular clasts. Suguio (1981) and Fernandes and Coimbra (2000) agree that this unit is the result of a braided fluvial depositional system.

The Uberaba Formation is similar to the São José do Rio Preto Formation but differs in compositional immaturity and color. It has been argued that this unit is rich in fragments of volcanic rocks from the Paranaiba High, and it is associated with a braided fluvial depositional environment (Hasui, 1968; Gravina et al., 2002; Fernandes and Coimbra, 2000).

The Marília Formation consists of fining-upward cycles, including matrix-supported conglomerates with intra and extraformational clasts, fine to very coarse sandstones (massive, crossstratified or ripple cross-laminated) and rare mudstones. Calcrete structures are quite common (laminar, prismatic or massive horizons), with abundant carbonate nodules (vertically elongated, branched or with irregular shape), horizontal cracks and rhizoliths. The Itaqueri Formation is quite similar to the Marília Formation but differs in a less expressive amount of carbonate cement and occurrence of layers with silica cementation. The Marília and Itaqueri formations are interpreted as alluvial fan deposits (Mezzalira, 1974; Soares et al., 1980; Riccomini, 1997a; Ladeira and Santos, 2005).

\subsection{Analysis of the stratigraphic ranges of selected fossils}

The plentiful biota of the Bauru Basin, despite the absence of any corroborative radiometric dating, allowed previous works to agree on a Cretaceous age for almost all of its deposits, except for the Itaqueri Formation that is usually assumed to have reached the early Paleocene (Riccomini, 1997a; Ladeira and Santos, 2005; Perrotta et al., 2005). This fossil assemblage is composed of conchostacans, ostracods, gastropods, bivalves, charophytes, palynomorphs, frogs, sauropods, birds, theropods, mammals, lizards, fishes, crocodylomorphs, turtles and pterosaurs. The stratigraphic ranges of the main identified fossil taxa present in Bauru Basin are summarized in Fig. 3, and their provenance and temporal range dataset are presented in the Supplementary Material.

With respect to vertebrates, although the species are endemic, almost all of the groups identified in the Bauru Basin indicate Cretaceous ages. For example, considering the oldest record of frogs and lizards in South America (Baéz et al., 2012; Estes and Price, 1973; Candeiro et al., 2009; Nava and Martinelli, 2011; Simões et al., 2015), the presence of these groups in the Marília and Adamantina formations indicates an age younger than Aptian. In addition, in view of the Campanian-Maastrichtian occurrences in South America (Marshall et al., 1983; Bonaparte, 1990; Gayet et al., 2001), a mammal specimen from the Adamantina Formation tentatively identified as placental by Bertini et al. (1993), could indicate a late Later Cretaceous age.

The record of fish has been revised as well. Alves et al. (2013) assigned the genus Asiatoceratodus to the specimen that was previously identified as Neoceratodus (Bertini et al., 1993), found in the Adamantina Formation. However, the authors noted that this specimen was found in a reworked clast and might not indicate the age for the Adamantina Formation. Most importantly, the presence of Siluriformes indicate that certain strata of the Adamantina and Marília formations are younger than late Santonian.

The age range of the Testudines taxa is estimated as Late Cretaceous (Gaffney et al., 2011; Romano et al., 2013). Menegazzo et al. (2015) noted the closer relationship among the Santo Anastácio form (from the Santo Anastácio Formation), "Podocnemis" brasiliensis (from the São José do Rio Preto and Araçatuba formations) and Portezueloemys patagonica (from the Portezuelo Formation, upper Turonian/lower Coniacian of Argentina). Moreover, P. mezzalirai and P. caiera from the Marília Formation are sister taxa of Lapparentemys vilavilensis from the Santa Lucía Formation, dated to the Paleocene of Bolivia (Gaffney et al., 2011; Menegazzo et al., 2015). Hence, the record of turtles indicates that the Santo Anastácio, Araçatuba and São José do Rio Preto formations are relatively older than the Marília Formation.

The Theropoda assemblage is indicative of Late Cretaceous age for the Adamantina, Marília, Uberaba and São José do Rio Preto formations. In Argentina, Megaraptora is recorded from Cenomanian to Santonian (Novas et al., 2008; Benson et al., 2010; Méndez et al., 2012; Martinelli et al., 2013), according to the 


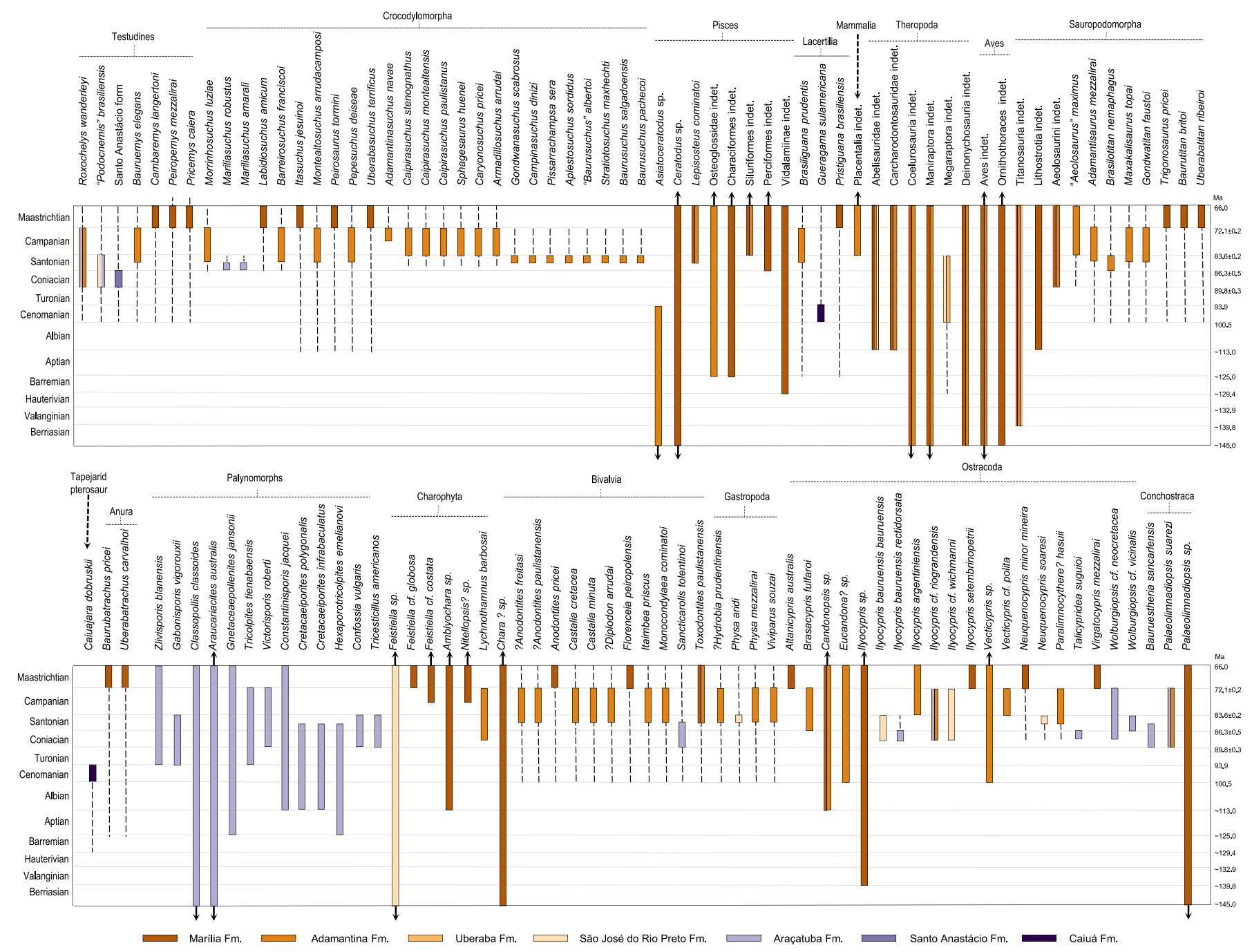

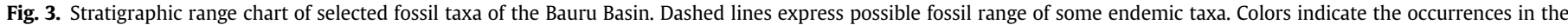
lithostratigraphic units. See Supplementary Material for details and references. Time scale from Cohen et al. (2013).

specimens found in the Mata Amarilla Formation, which were previously dated as Maastrichtian and redefined as Cenomanian (Varela et al., 2012; Novas et al., 2013). Consequently, the Megaraptora presence in the São José do Rio Preto and Uberaba formations (Méndez et al., 2012; Martinelli et al., 2013) might be indicative of an age older than the Santonian-Campanian boundary.

The new taxonomic assignments of the sauropods from the Adamantina, Marília and Uberaba formations also indicate the Late Cretaceous. The genus Aeolosaurus has been used to attribute Campanian-Maastrichtian to the Adamantina and Marília formations (Bertini et al., 1999; Santucci and Bertini, 2001), based on its Argentinian record. However, from the point of view of Martinelli et al. (2011) and Filippi et al. (2013), the evidence of this genus in the Bauru Basin is inconclusive. Certain specimens anteriorly identified as Aeolosaurus (Santucci and Bertini, 2001; Franco-Rosas et al., 2004; Marinho and Candeiro, 2005; Lopes and Buchmann, 2008; Santucci and Arruda Campos, 2011) have been assigned to Titanosauria (Martinelli et al., 2011) and Aeolosaurini indet (Martinelli et al., 2011; Filippi et al., 2013). Considering that Aeolosaurini is recorded in Argentina from the lower Coniacian to Maastrichtian (Filippi et al., 2013), it is possible to assume that the Adamantina, Marília and Uberaba formations were deposited within this interval. In addition, Machado et al. (2013a, b) noted that Brasilotitan nemaphagus from the Adamantina Formation appears to be closely related to Antarctosaurus wichmannianus (Upper Cretaceous, Argentina) and Bonitasaura salgadoi (Santonian, Argentina), which might also indicate a Santonian age for at least a portion of the Adamantina Formation.

The rich record of Crocodylomorpha in the Araçatuba, São José do Rio Preto, Adamantina and Marília formations also indicates the Late Cretaceous. In particular, Mariliasuchus is suggestive of Santonian in the upper portion of the Araçatuba Formation (or lower portion of the Adamantina Formation) because several studies (Andrade and Bertini, 2008; Turner and Sertich, 2010; Godoy et al. 2014; Pol et al., 2014) noted its closer relationship with Notosuchus from the Santonian of Argentina. The specimens of M. amarali and Mariliasuchus robustus are from an outcrop originally identified as the Araçatuba Formation (Carvalho and Bertini, 1999), and posteriorly assigned to the Adamantina Formation (Carvalho and Bertini, 2000; Zaher et al., 2006; Nobre et al., 2007). However, considering the descriptions of Carvalho and Bertini (2000) and Zaher et al. (2006), this outcrop is most likely to be the Araçatuba Formation, probably near the contact with the overlaying Adamantina Formation. Phylogenetic analyses have shown that Pissarachampsa is a sister taxon of Wargosuchus, from the Santonian of Argentina 
(Montefeltro et al., 2011; Godoy et al., 2014), which corroborates a Santonian age to at least a portion of the Adamantina Formation. In contrast, Adamantinasuchus might suggest a younger age for certain strata of the Adamantina Formation because it has been considered a sister taxon of Yacarerani (Novas et al., 2009; Iori and Carvalho, 2011; Pol et al., 2014), from the Maastrichtian Cajones Formation in Bolivia. Nevertheless, doubts exist related to the association of Adamantinasuchus with the Adamantina Formation because lithological descriptions were not published, and the indicated provenance is in the outcrop area of the Marilia Formation. Finally, Montefeltro et al. (2009) indicated the affinity of isolated crocodyliform teeth from the São José do Rio Preto Formation with middle Cretaceous taxa. This classification might indicate a relatively older age for the São José do Rio Preto Formation than that of the Adamantina and Marília formations.

The recent description of the Tapejaridae pterosaur Caiuajara dobruskii (Manzig et al., 2014) and the acrodontan lizard Gueragama sulamericana (Simões et al., 2015) brought clarification for the age of the poorly fossiliferous Caiuá Formation. This unit previously been dated as Late Cretaceous based on footprints tentatively associated to small theropods, dinosaurs and mammals (Leonardi 1977, 1989; Fernandes et al., 2013; Fernandes et al., 2008; Fernandes and Ribeiro, 2015). The record of G. sulamericana is also indicative of the Late Cretaceous (Simões et al., 2015), but according to Manzig et al. (2014), tapejarids are usually present in deposits ranging from Barremian to Cenomanian, as in the northeastern of Brazil (Kellner and Campos, 2007), China, Morocco (Wang and Zhou, 2003) and Spain Therefore, Cenomanian is the youngest age that can be assigned to the Caiuá Formation.

For invertebrate fossils, the endemism and paucity of information on bivalves, gastropods and conchostracans inhibit their use in biostratigraphy. However, the records of Physa aridi in the São José do Rio Preto Formation and Bauruestheria sancarlensis in the Araçatuba Formation offer additional information. According to Mezzalira (1974), P. aridi is quite similar to P. wichmanni, which has been recognized in the Aptian-Maastrichtian of Argentina, Lohan Cura, Allen, Los Alamitos and Augostura Colorada formations (Martinelli et al., 2007). Rohn et al. (2005) demonstrated the similarity between $B$. sancarlensis and selected species of the late Cenomanian-Santonian of Asia.

However, the noteworthy record of ostracods has been used to assign relative ages to the uppermost units of the Bauru Basin. These records also indicate a Late Cretaceous age, considering that Dias-Brito et al. (2001) express serious reservations about the identification of certain Early Cretaceous ostracods in the Adamantina and Marília formations (Paracypria? sp. 1, Paracypria? sp.2,?Reconcavona ?ultima, "Salvadoriella" sp., "Lycopterocypris" cf. angulate, Mantelliana sp., and "Hourcqia" sp.) and no further works confirmed the presence of these taxa. Thus, no conclusive evidence exists of Early Cretaceous ostracods in the Bauru Basin.

Recent studies extend the geographic distribution and temporal range of certain ostracod species in South America (Musacchio and Vallati, 2007; Carignano and Varela, 2011), and selected outcrops where these ostracods were collected by Dias-Brito et al. (2001) were redefined. In particular, certain outcrops in the city of Ibirá (São Paulo State) that were previously identified as the Adamantina Formation are assumed as related to the São José do Rio Preto Formation (Fig. 2), following the work of Fernandes and Coimbra (2000). Thus, the record of Ilyocypris wichmanni, Ilyocypris bauruensis rectidorsata and Neuquenocypris soaresi is associated with the São José do Rio Preto Formation. Moreover, certain localities with lacustrine facies association previously recognized as the Adamantina Formation in the region of Presidente Prudente and Álvares Machado cities (São Paulo State) likely represent the Araçatuba Formation, considering the studies of Paula e Silva et al.
(1994, 2006) and Gobbo-Rodrigues et al. (1999b). Consequently, the record of I. bauruensis rectidorsata, Talicypridea suguioi, Wolburgiopsis $c f$. neocretacea and $W$. vicinalis are associated with the Araçatuba Formation.

The Ostracoda taxa Altanicypris australis, Brasacypris fulfaroi, I. bauruensis, I. bauruensis rectidorsata, Ilyocypris setembrinopetrii, Neuquenocypris minor mineira, N. soaresi, Paralimnocythere? hasuii, T. suguioi, and Virgatocypris mezzalirai are endemic in Bauru Basin (Dias-Brito et al., 2001). However, Musacchio and Vallati (2007) recognize I. bauruensis and Talicyprideinae sp. in the upper Coniacian of Argentina (Plottier Formation), considering these specimens respectively similar to I. bauruensis rectidorsata and $T$. suguioi from the Araçatuba Formation. The subspecies $N$. minor mineira is found only in Marília Formation but is highly similar to $N$. minor (Dias-Brito et al., 2001), present in the Allen and Plottier formations of the upper Coniacian and Maastrichtian in Argentina (Musacchio and Simeoni, 1991; Musacchio and Vallatti, 2007). In addition, DiasBrito et al. (2001) consider A. australis from the Marília Formation to be closer to the Antarctosaurus szczechurae that is present in the Campanian and Maastrichtian of Asia.

Other ostracod species from the Bauru Basin have a more widespread distribution in South America. For example, Ilyocypris argentinensis from the Adamantina Formation (Gobbo-Rodrigues et al., 1999a) is also found in the Loncoche Formation of the Campanian-Maastrichtian in Argentina (Uliana and Musacchio, 1978; Parras and Griffin, 2013). Ilyocypris riograndensis is found in several localities in Adamantina (Dias-Brito et al., 2001) and Araçatuba formations (Gobbo-Rodrigues et al., 1999b) and is also described in the Plottier, Bajo de la Carpa and Anacleto formations of the upper Coniacian-Campanian in Argentina (Musacchio and Valati, 2007; Carignano and Varela, 2011). I. wichmanni from the São José do Rio Preto Formation in the Ibirá city region (Dias-Brito et al., 2001) is found in the Plottier (Musacchio and Vallati, 2007) and Anacleto formations (Musacchio, 2000). Wolburgiopsis cf. neocretacea present in Araçatuba Formation (Gobbo-Rodrigues et al., 1999b; Dias-Brito et al., 2001) are also recorded in the Plottier, Bajo de la Carpa and Anacleto formations of the upper Coniacian-Campanian in Argentina (Bertels, 1972; Uliana and Musacchio, 1978; Carignano and Varela, 2011). Similarly, W. vicinalis from the Santonian Bajo de La Carpa Formation (Uliana and Musacchio, 1978) is identified in the Araçatuba Formation (Gobbo-Rodrigues et al., 1999b; Dias-Brito et al., 2001). According to Colin et al. (2000), the genus Metacypris previously identified in the Adamantina Formation (Dias-Brito et al., 2001) was redefined as Vecticypris and is recorded from Cenomanian to Paleogene (Colin et al., 2000; Altinsaçli et al., 2004). In addition, Carignano and Varela (2011) stated that the specimens of Vecticypris sp. from the Allen Formation of the upper Campanian and Maastrichtian in Argentina are highly similar to Vecticypris cf. polita described in the Adamantina Formation (Dias-Brito et al., 2001).

With respect to the record of charophytes, several specimens originally described as Chara barbosai (Petri, 1955) of the Adamantina Formation (Dias-Brito et al., 2001) were included in the new combination Lychnothamnus barbosai (Musacchio, 2006, 2010), which is also identified in the upper Coniacian of Argentina. From the point of view of Dias-Brito et al. (2001), selected gyrogonites from the Marília Formation might be related to Globichara (Pseudoharrisichara), but the subspecies Pseudoharrisichara (Musacchio, 1973) were included in Lychnothamnus (Musacchio, 2010), and thus, the classification of these specimens remains inconclusive. More important are the charophytes taxa indicative of Maastrichtian age for the Marília Formation. According to Dias-Brito et al. (2001), the gyrogonites of Feistella globosa are comparable to those from Maastrichtian of Spain (Grambast and Guttierrez, 1977), and the gyrogonites of $F$. costata are similar to 
those described in the Maastrichtian and Paleocene of Peru and Ecuador (Jaillard et al., 1993, 1994). The gyrogonites of Amblyochara sp. are quite similar to those described by Musacchio (1973) in the Yacoraite Formation of the Maastrichtian in Argentina (Dias-Brito et al., 2001). This genus is also recorded in the Campanian and Maastrichtian of Peru and Bolivia (Jaillard et al., 1993, 1994). The genus Nitellopsis, tentatively identified in the Marília Formation (Dias-Brito et al., 2001), is documented from the upper Campanian to Paleocene of Peru and the Acre Basin in Brazil (Jaillard et al., 1993, 1994; Musacchio, 2000).

The record of palynomorphs is restricted to the Araçatuba Formation from one locality in São Carlos City, São Paulo State (Fig. 2). According to Lima et al. (1986), the palynological assemblage of these strata indicates a Coniacian age. For the authors, this locality corresponds to the "Itaqueri Lithofacies", the upper portion of the Bauru Basin. Conversely, Fernandes and Coimbra (1996) and Gobbo-Rodrigues et al. (1999b) consider that these strata are located in a basal position. Castro et al. (2002) described this outcrop as the contact of fluvial and lacustrine facies, denominated these strata as the São Carlos Formation and concluded a Coniacian-Santonian age. The description of these outcrops corresponds closely to observations of the contact between the Adamantina (fluvial) and Araçatuba (lacustrine) formations in other regions, and the water wells in the region of São Carlos confirm the occurrence of Bauru deposits in this area (Sallun Filho et al., 2009). Consequently, this locality is understood as the Araçatuba Formation. Thus, the record of the angiosperm pollen grains of Victorisporis roberti, Confossia vulgaris and Tricesticillus americanus (Lima et al., 1986; Vallati, 2010) limit the base of the temporal range of the Araçatuba Formation to Coniacian. Additionally, Cretacaeiporites polygonalis, C. infrabaculatus and Hexaporotricolpites emelianovi limit the top of this range to the early Santonian.

\subsection{Age of the lithostratigraphic units}

Based on the range of the fossils discussed previously, the age of the Bauru Basin deposits can be estimated from the Cenomanian to early Paleocene (Fig. 3). However, the evidence in each formation is not strictly accurate. Fossils are not yet recorded in certain units, and in others, the record is still poor. In addition, the paleontological data are not uniform throughout the entire basin, and the level of knowledge differs depending on the location and density of studies, which are generally concentrated on the east side of the basin.

The association of $C$. dobruskii, G. sulamericana and theropod footprints is suggestive of Cenomanian age for the Caiuá Formation. The Pirapozinho Formation can be considered partially chronocorrelated to the Caiuá Formation; these formations are in lateral contact, and the Pirapozinho Formation partially overlies the Caiuá Formation. Therefore, the age of the Pirapozinho Formation is estimated as Cenomanian-early Turonian?, although fossils have not yet been recorded in this unit.

The palynological assemblage assigns an Coniacian-early Santonian age to the Araçatuba Formation, which is consistent with the presence of the ostracods I. bauruensis rectidorsata, I. riograndensis, T. suguioi, Wolburgiopsis neocretacea, $W$. vicinalis, the conchostracan B. sancarlensis and the crocodyliform Mariliasuchus. Taking into account the stratigraphic relationship of the Santo Anastácio Formation with the adjacent units, it is assumed to be younger than the Caiuá and Pirapozinho formations, partially chronocorrelated with the Araçatuba Formation, and older than the other formations, and with the additional consideration of the record of the fossil turtle in the Santo Anastácio form, the age of the Santo Anastácio Formation is estimated as Coniacian. Additionally, although no record of fossils exists in the Birigui Formation, its age can be estimated as late Santonian because it is interdigitated with the Araçatuba Formation and occurs in a position upper to the Santo Anastácio Formation.

The age of the Adamantina Formation is late Santonian-Campanian, taking into account the record of I. argentinensis, I. riograndensis, V. polita, P. hasui, Aeolosaurini, B. nemaphagus, Placentalia, Siluriformes, P. sera, Campinasuchus dinizi and Adamantinasuchus navae.

The age of the São José do Rio Preto Formation is estimated as Santonian, considering its stratigraphic relationship, i.e., partially correlated with the Araçatuba and Adamantina formations and overlying the Santo Anastácio Formation as well as the association of "P." brasiliensis, Megaraptora, I. bauruensis, I. wichmanni and isolated teeth of crocodyliformes.

Certain studies have noted that magmatic rocks of the Paranaíba High constituted a source of sediments for the Uberaba Formation (Hasui, 1968; Fúlfaro and Barcelos, 1991; Gravina et al., 2002; Batezelli et al., 2005). Considering that different events of alkaline magmatism occurred in this area between 100 and 79 (Hasui and Haralyi, 1991; Brod et al., 2005; Riccomini et al., 2005) and the record of Megaraptora in the Uberaba Formation, the deposition of this unit is assumed older than the Santonian-Campanian boundary, and its age can be considered Santonian.

Taking into account the occurrence of $P$. mezzalirai, P. caiera, Siluriformes, Perciformes, F. globosa, F. costata, Nitellopsis, A. australis and N. minor mineira, Maastrichtian age is indicated for the Marilia Formation. Although the range of certain of these taxa crosses the K-T boundary, the presence of Theropoda and Sauropodomorpha limits the deposition of the Marília Formation to the Cretaceous.

The Itaqueri Formation has been correlated with the base of the Marília Formation or considered younger (Fúlfaro and Perinotto, 1996; Riccomini, 1997a; Ladeira and Santos, 2005), although there is no fossil record. Riccomini (1997a) noted the PaleoceneEocene age of Itaqueri Formation, considering that its silicified sandstones resulted from hydrothermalism related to alkaline magmatism in the Jaboticabal region, as proposed by Coimbra et al. (1981). However, the age of this magmatic event is controversial (Coimbra et al., 1981; Gomes and Valarelli, 1970; Coutinho et al., 1982) and the K/Ar dating might be masked by deuteric alteration (Valarelli et al., 1985). In addition, Ladeira and Santos (2005) consider this silicification a result of pedogenic processes but also indicate Cenozoic age for the Itaqueri Formation. In agreement with Perrotta et al. (2005), in this study, the Itaqueri Formation is considered Maastrichtian? -early Paleocene until fossil discoveries can clarify its age.

\subsection{Sedimentation}

As demonstrated by the paleontological data, the sedimentation of the Bauru Basin began in the Cenomanian with the deposition of the Caiua and Pirapozinho formations, superimposed on the basalts of the Serra Geral Formation (Fig. 4A). The isopach map of the preserved entire basin-fill demonstrates that its geometry is lightly asymmetric (Fig. 4B) with two major depocenters. The isopach pattern is concentric, lacking evidence of synsedimentary faulting. In addition, the isopach map of the Cenomanian-Turonian sequence makes it evident that its deposition was not uniform throughout the entire basin and was limited to the southern area (Fig. 4C), where the maximum preserved thickness reaches $271 \mathrm{~m}$ (well 2AN-0001-BR, SIAGAS n.d.).

After un unconformity that separates the Santo Anastácio Formation from the Pirapozinho and Caiuá formations, previously recognized by Paula and Silva et al. (2009), a new depositional cycle began in the Coniacian in the Bauru Basin, initiated with the 
Araçatuba and Santo Anastácio formations and followed by the Birigui, São José do Rio Preto, Uberaba and Adamantina formations (Fig. 5). This Coniacian-Campanian depositional cycle overlaps only partially with the Cenomanian-Turonian succession. Indeed, the isopach map of this stratigraphic interval demonstrates the significant migration of its depocenter, from northern Paraná State to north-northwestern São Paulo State (Fig. 4D), representing a cratonward shift of approximately $250 \mathrm{~km}$. The maximum preserved thickness of the Coniacian-Campanian sequence is $226 \mathrm{~m}$ in the São José do Rio Preto region.

Immediately after the Late Campanian tectonic phase, accommodation was created in the Bauru Basin, enabling the sedimentation of alluvial fan deposits (Marília and Itaqueri formations) (Fig. 2). These deposits partially recover the Santonian-Campanian Adamantina Formation onlapping the north and east borders of the basin. Apparently, this new cycle expresses a shift of the basin's depocenter, but insufficient information exists to reconstruct the basin-fill geometry of this stratigraphic interval. The sedimentation in the Bauru Basin ended with the Maastrichtian-lower Paleocene sequence.

The Bauru Basin is primarily bounded by Paleozoic-Mesozoic sedimentary rocks of the Paraná Basin and the basalts of the Serra Geral Formation (Fig. 1). Along the northwestern, northeastern and southwestern it is also bounded by Cretaceous alkaline magmatic rocks and Paleoproterozoic rocks of the basement, exposed on the Asunción Arch, Rondonópolis Anteclise and Paranaíba High. This areas supplied sedimentary, magmatic and metamorphic detritus to the basin. For example, the Asunción Arch was established in the Early Paleozoic (Almeida, 1983; Gomes et al., 2013), where deposition and erosion alternated during the Chaco-Paraná Basin evolution (Zalán et al., 1990; Milani et al., 1994, 2007). From the Valanginian to Aptian, alkaline magmatism occurred in this region, and the Asunción Arch was uplifted during the Cretaceous (CominChiaramonti et al., 1999; Comin-Chiaramonti et al., 2014; Gomes et al., 2013); therefore, it might have been a source area of sediments for the Bauru Basin. Indeed, Coimbra (1976) recognizes a pre-existent sedimentary and volcanic (basalt) provenance for the lower interval of the basin, corresponding to the CenomanianTuronian sequence.

In the following sequences, from Coniacian to Paleocene, occurred a relatively more cratonal derivation of the sediments. The Paranaíba and Rondonópolis structures, that separate the Bauru
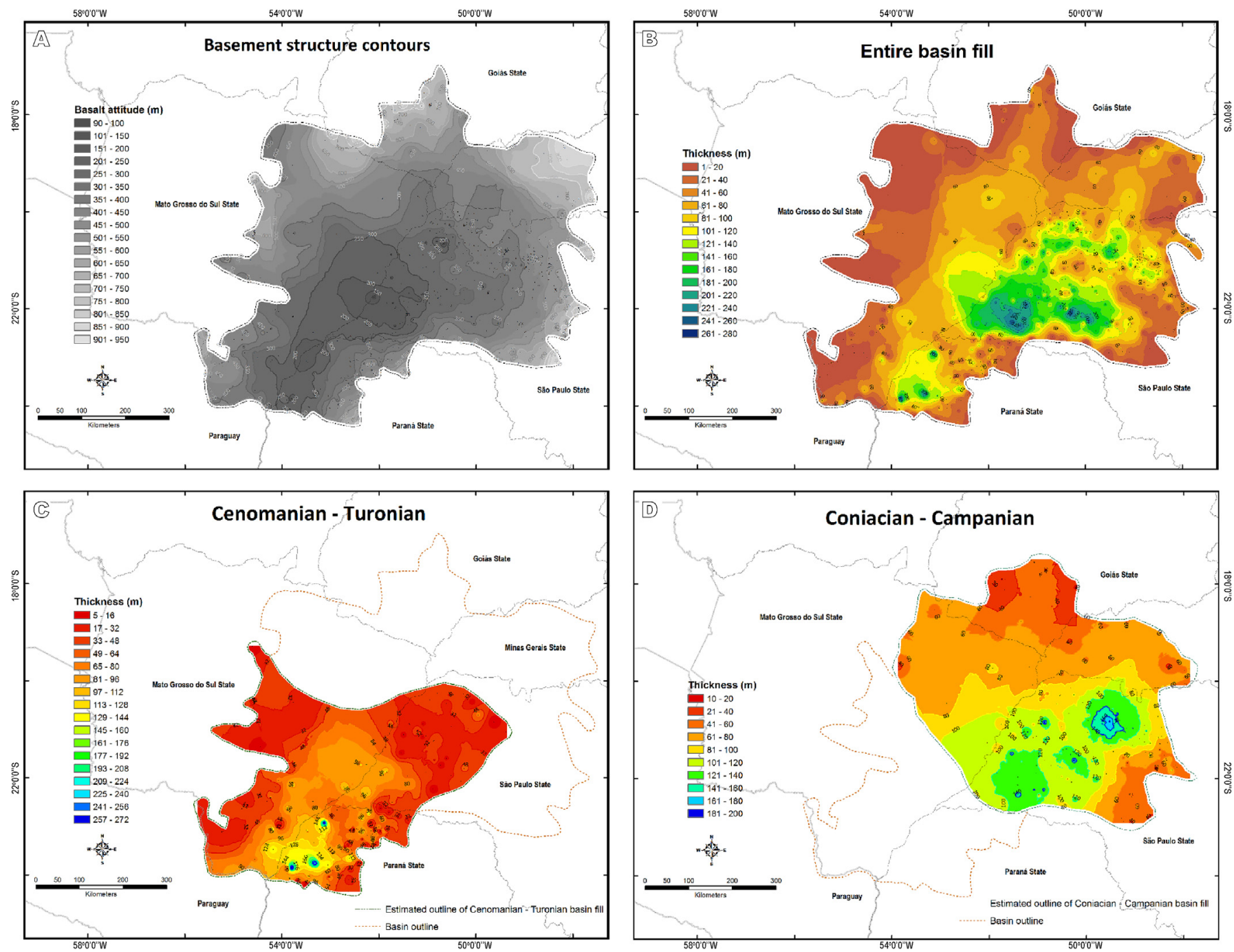

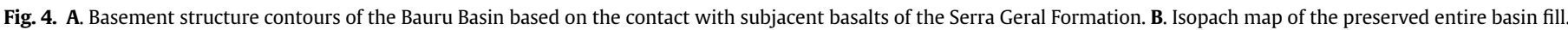

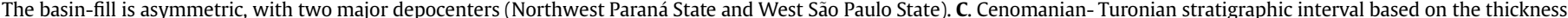

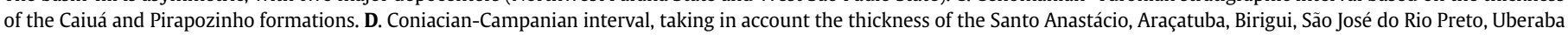
e Adamantina formations. 


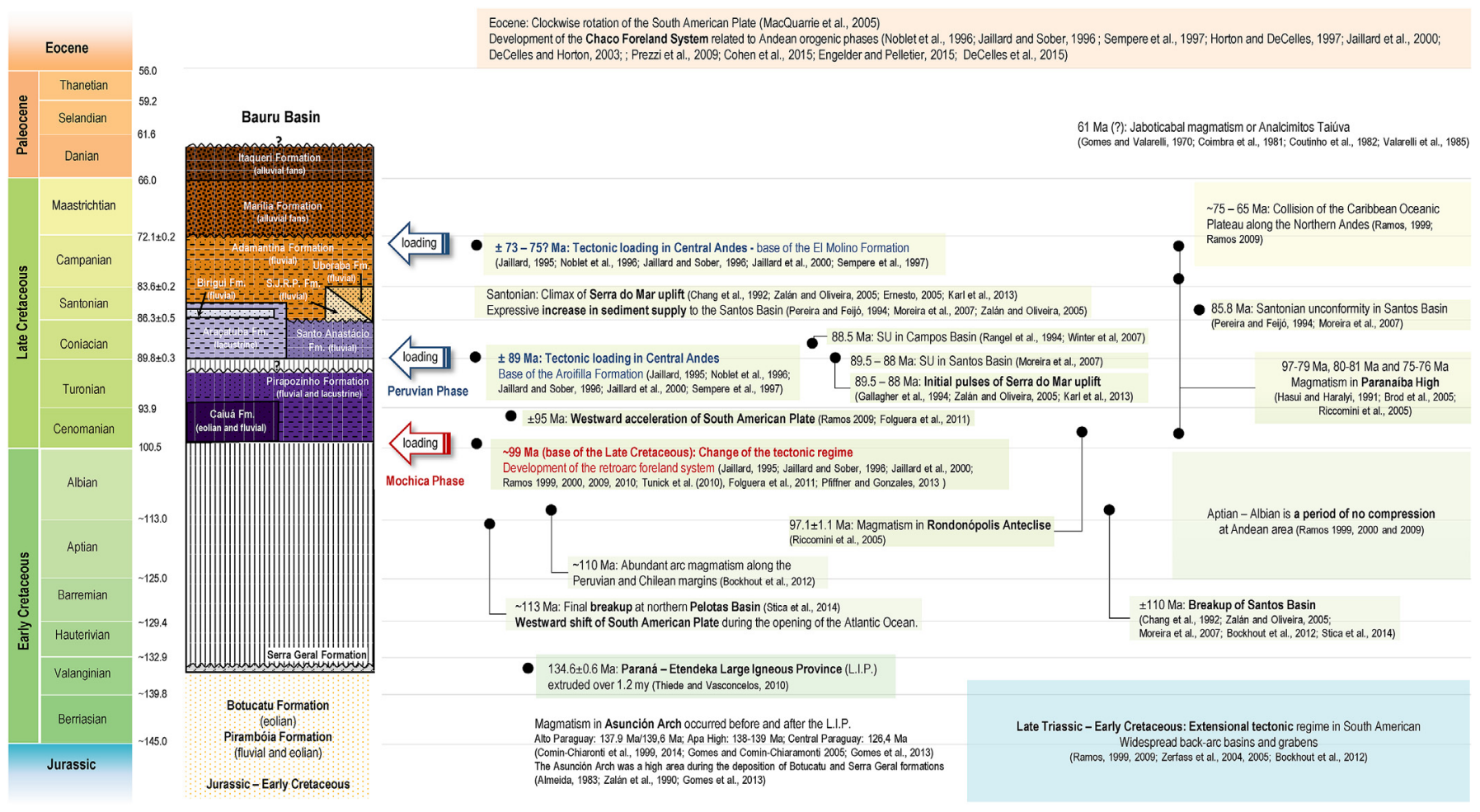

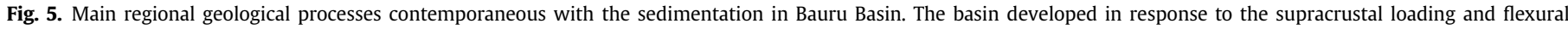

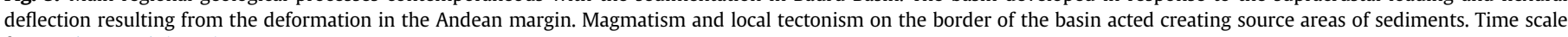
from Cohen et al. (2013).

Basin from the Cretaceous deposits of the São Francisco and Parecis basins, represented significant source areas. These structures were uplifted during the Late Cretaceous, as evidenced by magmatism since the Cenomanian (Fig. 5) (Hasui and Haralyi, 1991; Brod et al., 2005; Riccomini et al., 2005). Actually, petrographic provenance analysis recognize an important contribution of alkaline magmatic rocks from the Paranaíba High in the Uberaba Formation (Coimbra, 1976; Gravina et al., 2002; Batezelli et al., 2005) and detrital zircons $(\mathrm{U}-\mathrm{Pb})$ analysis indicate provenance from the crystalline basement exposed on the Rondonópolis Anteclise in the Adamantina Formation (Dias et al., 2011).

In addition, the initial pulses of the Serra do Mar uplift began at 89.5-88 Ma (Gallagher et al., 1994; Zalán and Oliveira, 2005; Karl et al., 2013), which is reflected in the Santos and Campos basins in the form of Coniacian subaerial unconformities (Rangel et al., 1994; Winter et al., 2007; Moreira et al., 2007). The climax of this uplift occurred in the Santonian (Chang et al., 1992; Zalán and Oliveira, 2005; Ernesto, 2005; Karl et al., 2013), generating an expressive increase in sediment supply to the Santos Basin on the east (Pereira and Feijó, 1994; Zalán and Oliveira, 2005; Moreira et al., 2007) and possibly to the Bauru Basin on the west.

Finally, the Maastrichtian-Paleocene sequence is rich in basaltic and sedimentary rock clasts of the Paraná Basin, mostly from east and north adjacent source areas (Riccomini, 1997b; Gravina et al., 2002).

\section{Geodynamic evolution}

The opening of the South Atlantic Ocean and the westward migration of the South American Plate resulted in a profound change in the tectonic setting of the South American Plate. Sedimentation in Bauru Basin occurred simultaneously with the early stages of the Andean uplift during the Late Cretaceous (Mochica and Peruvian phases). The Mochica Phase of orogeny (Mégard, 1984; Jaillard et al., 2000) was responsible for the initial development of a retroarc foreland system. The foredeep depozone of this system is characterized by the Andean Basin, which developed in an elongated area parallel to the west margin of South America and includes the Potosí, Marañon, Acre and Oriente basins (Reyes, 1972; Sempere, 1995; Jaillard et al., 2000). In a cratonward position parallel to the Andean Basin are located the Bauru, Parecis and Solimões basins (Fig. 1).

Herein, we propose that the Bauru Basin developed in response to supracrustal load and flexural deflection resulting from the beginning of the early Andean orogeny, during the westward absolute motion of the South American Plate and subduction of the Farallon Plate. The Bauru Basin is in the back-bulge province of a retroarc foreland system developed adjacent to the western margin of South America (Fig. 6). The deposits of the Bauru Basin did not develop uniformly throughout the entire basin, with evidence of migration of its depocenter. The Andean foredeep basins also migrated eastward during the Peruvian pulses of the Andean orogeny (Sempere et al., 1997). This event occurred after the migration of the orogenic front during the pulses of orogeny.

\subsection{Preceding tectonic setting - Triassic to early Cretaceous}

Before the development of the Bauru Basin, the South America Plate was subjected to an extensional regime during most of the Triassic to Early Cretaceous, which was conditioned by the breakup of Gondwana (Sempere, 1995; Ramos, 2010). This tectonic process created regional tectonism, magmatism and creation of accommodation in sedimentary basins. In the west margin, grabens and back-arc basins have been established associated with reactivated basement structures (Jaillard et al., 2000; Ramos, 2009; Zerfass et al., 2004, 2005; Sempere, 1995; Sempere et al., 1997; Maloney 
et al., 2013). In the Solimões Basin, an echelon arrangement of folds and faults developed during the Late Jurassic (Caputo (1991). In the region where the Andean Basin later developed, were deposited the eolian deposits of the Ichoa and Yantara formations in Bolivia (Moretti et al., 1996) and the upper portion of the Juruá Mirim Formation in the Acre Basin (Fig. 7) (Feijó and Souza, 1994; Cunha, 2007). The fluvio-eolian Triassic or Jurassic deposits of the Pirambóia Formation and the eolian Late Jurassic-Early Cretaceous deposits of the Botucatu Formation were deposited in the Paraná Basin (Caetano-Chang, 1997; Assine et al., 2003; Milani et al., 2007a, b; Soares et al., 2008). The Parecis Basin was also submitted to extensional tectonics that generated accommodation for the eolian Jurassic deposits of the Rio Ávila Formation (Bahia et al., 2006). In addition, this Early Cretaceous extensional regime resulted in the development of a the Salta rift system in northern Argentina (Salfity and Marquillas, 1994; Marquillas et al., 2005; Ramos, 2009; Siks and Horton, 2011; Maloney et al., 2013), whose distribution has been associated with the triple junction involving the Amazonian, Arequipa and Pampia cratons (Comínguez and Ramos, 1995).

During this extensional regime, magmatism occurred in most sedimentary basins of South America (Fig. 7), including the Anari $(198.0 \pm 0.8 \mathrm{Ma})$ and Tapirapuã $(196.6 \pm 1.8 \mathrm{Ma})$ magmatic subprovinces of the Parecis Basin and the Penatecaua magmatism in the Solimões and Amazonas basins (Marzoli et al., 1999; De Min et al., 2003; Wanderley Filho et al., 2007; Cunha et al., 2007), all belonging to the extensive magmatism of the Central Atlantic Magmatic Province (CAMP) (Marzoli et al., 1999; De Min et al., 2003; Bahia et al., 2006). In Southeast South America and West Africa, the Paraná-Etendeka Large Igneous Province (LIP) extruded over 1.2 m.y. at 134.6 \pm 0.6 Ma (Thiede and Vasconcelos, 2010). In Brazil, the LIP is characterized by the Serra Geral Formation, covering most areas of the sedimentary rocks of the Paraná Basin, which are thicker than $1500 \mathrm{~m}$ in the Bauru Basin area (Zalán et al., 1990; Milani, 2003). These large continental flood basalts have been assumed as a result of decompressional melting of abnormally hot mantle brought to the base of the lithosphere by plumes (White and McKenzie, 1995) and are usually related to the Tristan da Cunha plume (Bizzi and Vidotti, 2003). However, paleomagnetic reconstructions and geochemical and isotopic data do not support this hypothesis (Ernesto, 2005; Ernesto et al., 2002; Rocha-Júnior et al., 2012), and the LIP has been linked to local hotter mantle conditions due to the combined effects of edge-driven convection and large-scale mantle warnings (Rocha-Júnior et al., 2013).

In this setting, during the final breakup of western Gondwana, the South Atlantic Ocean evolved as a branch of a Jurassic-Cretaceous intraplate rift between the African and South American plates (Heine et al., 2013). The breakup of the southeastern Brazilian continental margin occurred in steps during the Early Cretaceous. In different segments of the Pelotas Basin (Fig. 1), this process occurred from the early Barremian to late Aptian (Stica et al., 2014). In the Santos and Campos basins, this process occurred near 113-115 Ma (Moreira et al., 2007; Winter et al., 2007; Stica et al., 2014). The final breakup between South America and Africa occurred in the equatorial Atlantic domain at $103 \mathrm{Ma}$ (Heine et al., 2013).

\subsection{Development of the retroarc foreland system}

\subsubsection{Initial stage - Cenomanian to Turonian}

The breakup between South America and Africa in the late Albian began the westward absolute motion of the South American Plate (Jaillard and Soler, 1996; Ramos, 1999, 2000, 2009; Jaillard et al., 2000; Folguera et al., 2011; Boekhout et al., 2012; Maloney et al., 2013) and increased the velocity of the subduction of the oceanic lithosphere beneath the Andean margin (Ramos, 2009; Folguera et al., 2011). The subduction began at a steep angle, but in some segments of the Andes, evidence exists of shallow subduction by the Late Cretaceous (Jaillard et al., 2000; Ramos, 2009; Folguera et al., 2011; Spagnuolo et al., 2012).

The start of compressional deformation in Central Andes occurred at the base of the Late Cretaceous, with the beginning of the Andean uplift younger than 98.6 Ma (Tunik et al., 2010), characterizing the Mochica orogenic phase in the Central segment (Mégard, 1984; Jaillard et al., 2000). This tectonic phase is the earliest major compressional Cretaceous event in the Central Andes and has been interpreted as responsible for significant crustal shortening (Jaillard, 1994). Several studies developed in different areas of the Andean orogen have also described the initial uplift of this subduction-related orogen at Cenomanian (Mégard, 1984; Jaillard, 1994; Jaillard et al., 2000; Mosquera and Ramos, 2006; Jaimes and Freitas, 2006; Zamora Valcarce et al., 2006; Giulio et al., 2012; Pfiffner and Gonzalez, 2013; Fennel et al., 2015).

The Mochica orogeny is responsible for the initial development of the foredeep Andean Basin from northern Peru to south of Bolivia, parallel to the Andean margin (Fig. 8) (Reyes, 1972; Jaillard and Sempere, 1991; Sempere et al., 1997). In the south, a set of arches formed a boundary between the Andean Basin and the Salta Basin in northern Argentina. It is widely accepted that the Salta

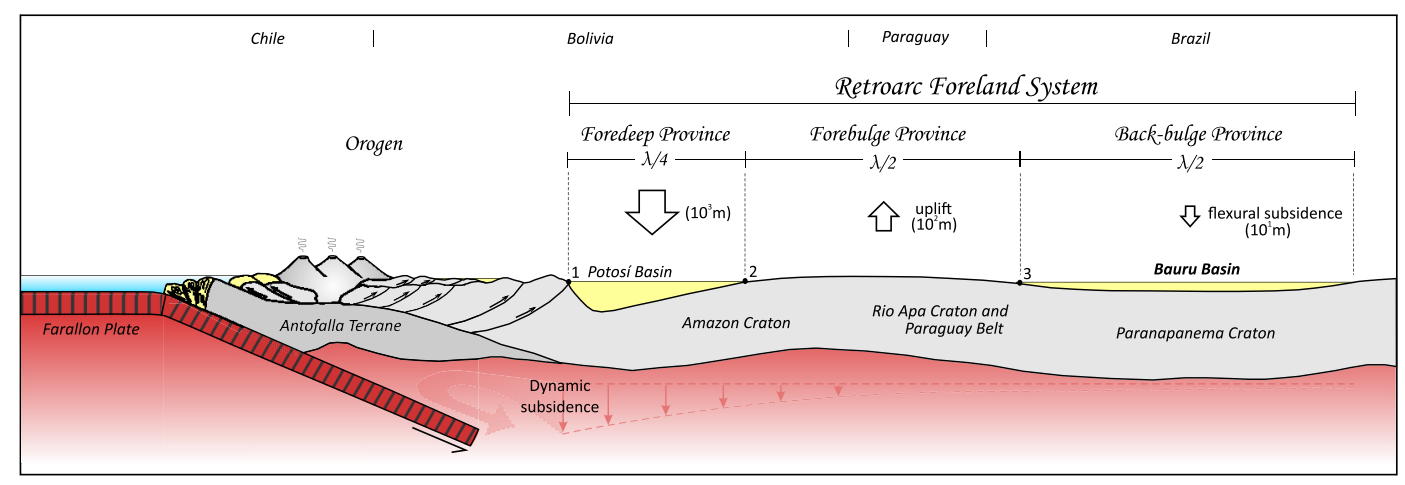

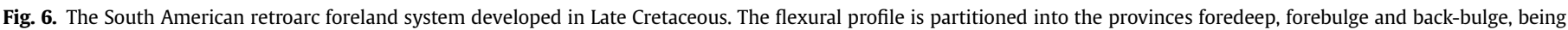

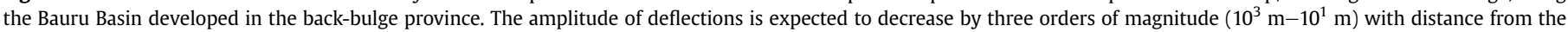

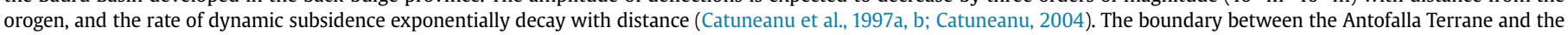

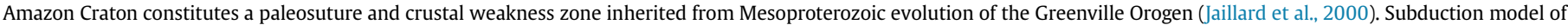

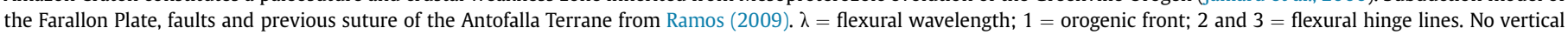
scale. 

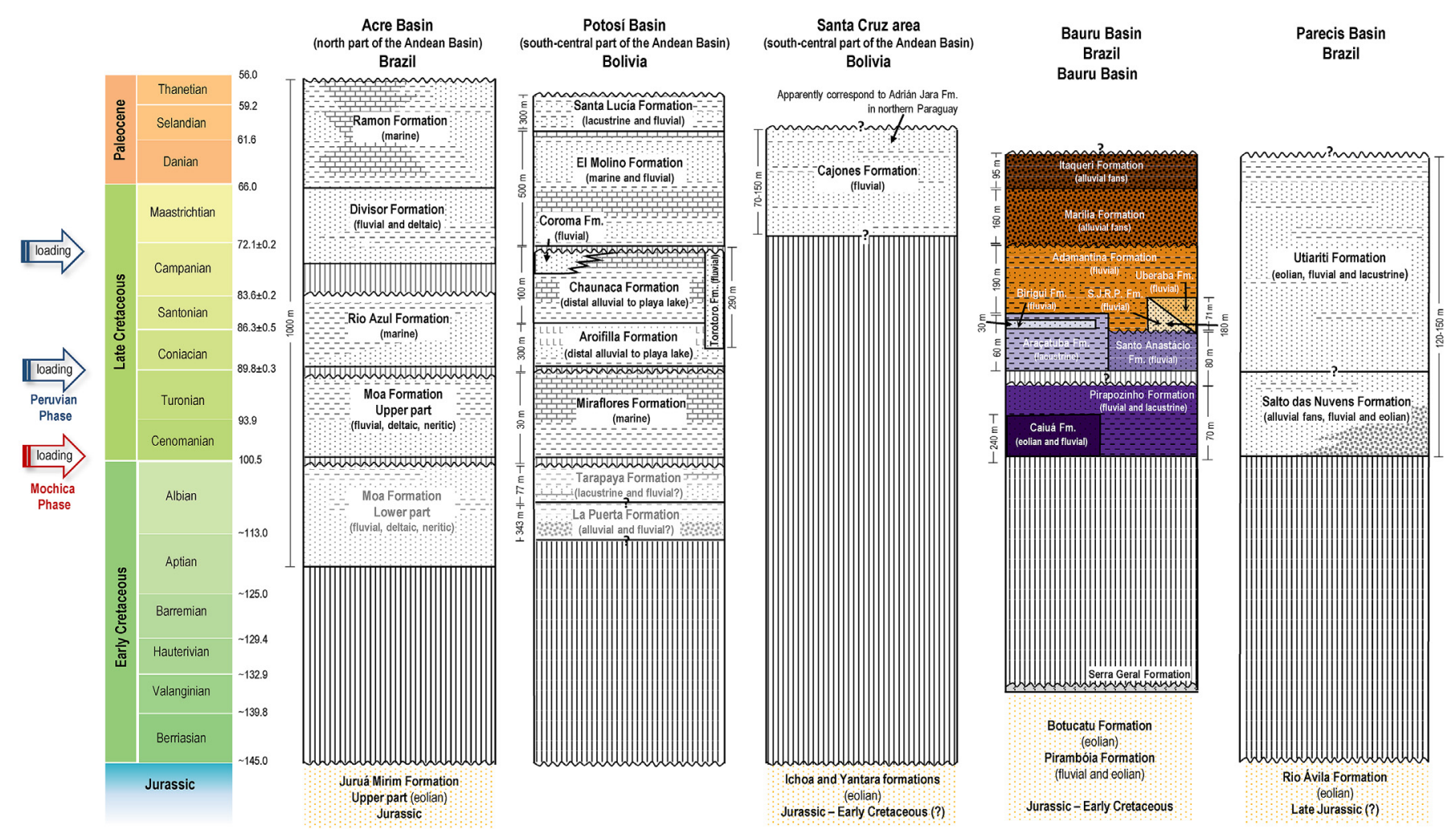

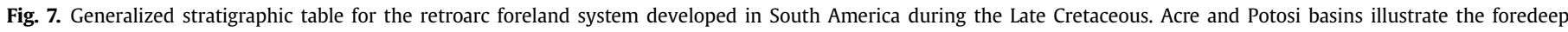

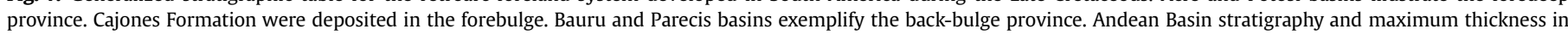

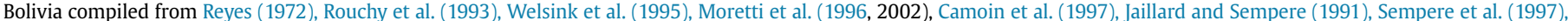

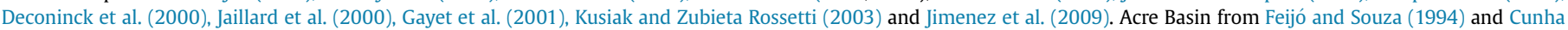
(2007). Parecis Basin from Bahia et al. (2006) and Batezelli et al. (2014). Time scale from Cohen et al. (2013).

Basin resulted from the Early Cretaceous extensional regime, with sedimentation in a series of fault-bounded basins related either to the opening of the South Atlantic or back-arc extension (Salfity and Marquillas, 1994; Siks and Horton, 2011; Becker et al., 2015). As a result, from the Valanginian to Campanian, the sedimentation in the Salta Basin has been assumed as a rift phase (Hernandez et al., 1999; Masaferro et al., 2003; Siks and Horton, 2011), and the Maastrichtian-Paleocene sedimentation has been attributed to post-rift thermal subsidence, which began with the Yacoraite Formation (Salfity and Marquillas, 1994; Comínguez and Ramos, 1995; Masaferro et al., 2003; Siks and Horton, 2011; Marquillas et al., 2011). Usually, only the Cenozoic sequence of the Salta Basin has been interpreted as a foreland basin (Masaferro et al., 2003; DeCelles et al., 2011; Siks and Horton, 2011; Becker et al., 2015).

A marine transgression in the Andean foredeep basin, from the north toward the south, occurred in the Cenomanian (Jaillard, 1994; Camoin et al., 1997; Martinez and Mamani, 1995; Jaillard and Sempere, 1991; Sempere, 1995; Sempere et al., 1997) and is represented (for example) by the upper portion of the Moa Formation in the Acre Basin (Feijó and Souza, 1994; Cunha, 2007) and the Miraflores Formation in the Potosí Basin (Fig. 7) (Jaillard and Sempere, 1991; Sempere, 1995; Sempere et al., 1997). The Cenomanian age of the Miraflores Formation is well established by the record of Neolobites vibrayeanus (Reyes, 1972; Jaillard and Sempere, 1991; Wiese and Schulze, 2005). However, the ages of the subjacent nonfossiliferous La Puerta and Tarapaya formations are controversial (Reyes, 1972; Jaillard et al., 2000), raising doubts related to the relationship of these units with the foreland system or the previous extensional regime. In southern central Bolivia, the total Cretaceous succession is approximately $1200 \mathrm{~km}$ thick and is composed of marine and nonmarine deposits (Sempere et al., 1997).

Late Cretaceous sedimentation also occurred in cratonward areas parallel to the Andean Basin characterizing the Bauru, Parecis and Solimões basins (Figs. 7 and 8). The Cretaceous of the Parecis Basin is composed of nonmarine deposits of the Salto das Nuvens and Utiariti formations (Parecis Group), occupying a relative wide area and with a maximum preserved thickness of approximately $150 \mathrm{~m}$ (Bahia et al., 2006). The fossil record provides evidence of Late Cretaceous age for the undifferentiated Parecis Group consisting of theropods (Kellner and Campos, 2002; Bittencourt and Langer, 2011), the sauropod Gondwanatitan (Franco-Rosas et al., 2004), and crocodyliformes similar to Mariliasuchus and Notosuchus (Marconato, 2006). The underlying eolian deposits of the Rio Ávila Formation are assumed to be Late Jurassic (Batezelli et al., 2014), although no fossil record exists to support this hypothesis. The sedimentation of the thick Alter do Chão Formation in the Solimões $(1250 \mathrm{~m}$ ) and Amazonas $(1000 \mathrm{~m})$ basins began at the same time. According to Silva et al. (2003), the preservation of these fluvial and alluvial fan deposits in the Solimões Basin is related to the Andean orogeny events. However, the age assignment of the Alter do Chão Formation is controversial, i.e., early CenomanianMaastrichtian (Daemon and Contreiras, 1971) or late Aptian for the lower portion and Cenomanian for the middle portion (Dino et al., 1999), with a lack of biostratigraphic definition for its upper portion (Dino et al., 2012; Mendes et al., 2012).

There is no record of Cenomanian-Turonian sedimentation in the region between the Potosí Basin in Bolivia (south-central portion of the Andean Basin) and the Bauru and Parecis basins in Brazil (Figs. 7 and 8), which indicates the existence of an uplifted area that was not received or did not preserve sediments at this 


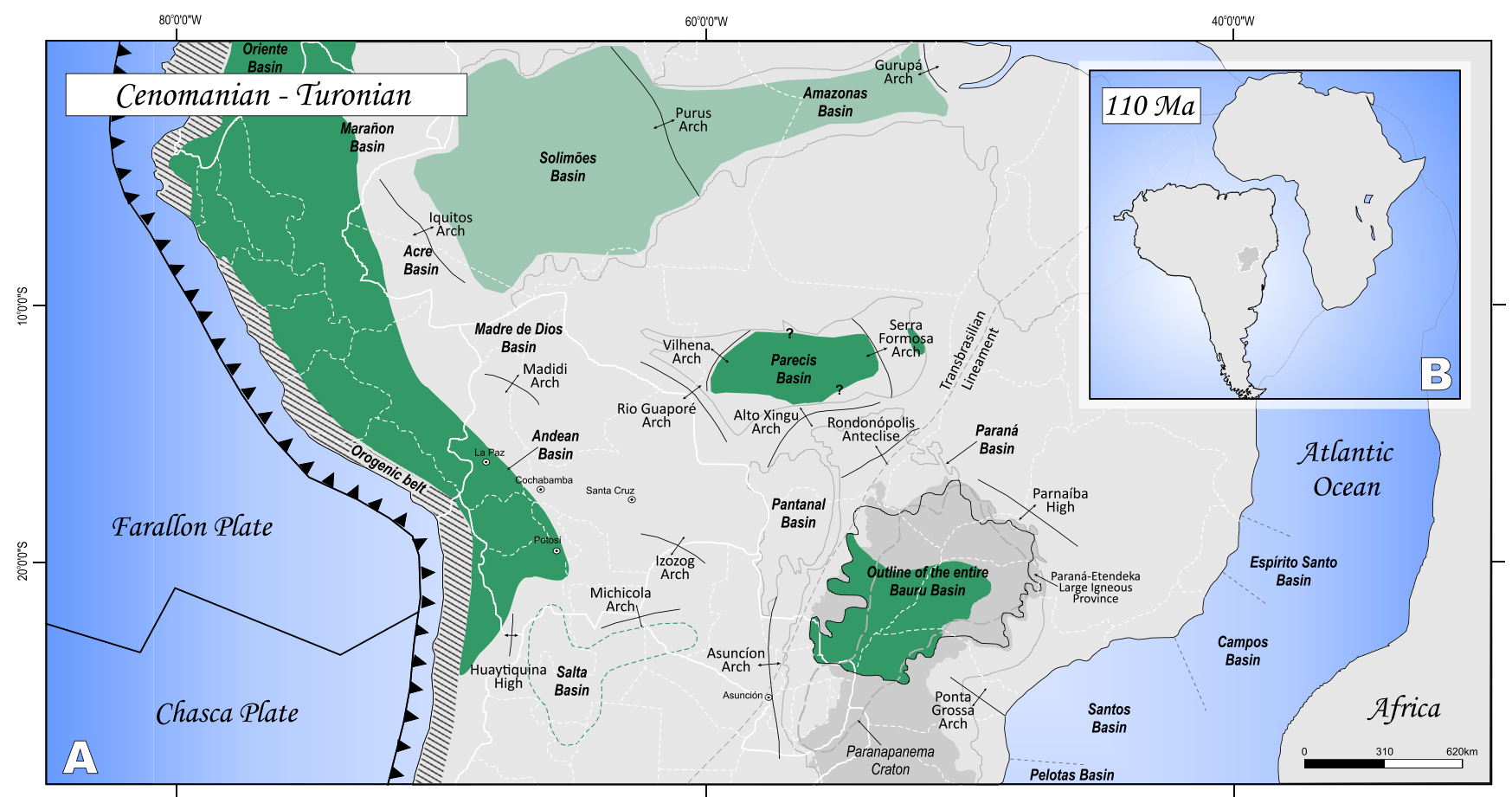

Estimated depositional areas during Cenomanian-Turonian

Estimated depositional area of the Alter do Chão Formation during the Late Cretaceous

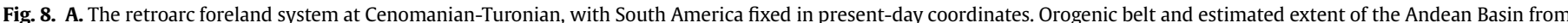

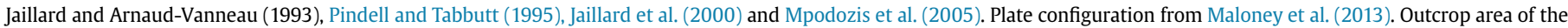

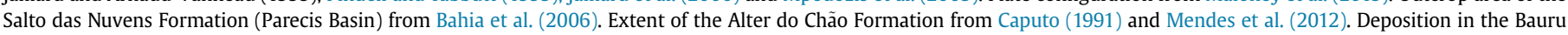

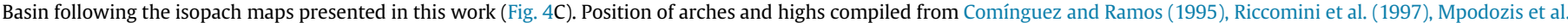

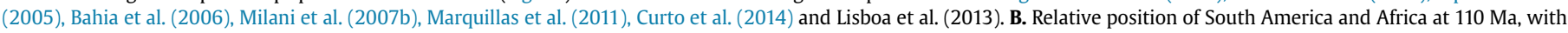
Africa fixed in present-day orientation (Heine et al., 2013).

time.

\subsubsection{Migration of the system - Coniacian to Campanian}

By the late Turonian to earlier Coniacian, a new event of Andean orogeny occurred in the Central Andes and portions of the North Andes, which characterize the first event of the Peruvian Phase (Noblet et al., 1996; Jaillard and Soler, 1996; Sempere et al., 1997; Jaillard et al., 2000). The Peruvian Phase extended from the Coniacian to early Paleocene and was characterized by relatively short deformation events: the Turonian-Coniacian boundary ( $88 \mathrm{Ma})$, Santonian ( $85 \mathrm{Ma}$ ), late Campanian ( 80-75 Ma) and late Maastrichtian $(\sim 70-65 \mathrm{Ma})$ alternating with longer intervals of tectonic quiescence (Jaillard, 1994; Jaillard and Soler, 1996; Sempere et al., 1997; Jaillard et al., 2000). The subduction that began near the Aptian-Albian boundary in the west margin of South America accelerated after 90-95 Ma, simultaneously with the acceleration of the absolute motion of the South American plate during the opening of the South Atlantic Ocean (Folguera et al., 2011; Ramos, 1999, 2000, 2009; Maloney et al., 2013).

For Jaillard et al. (2000), the Turonian-Coniacian boundary is marked by the end of carbonate sedimentation in the Andean Basin and is replaced by marine shales in the north portion and red shales and siltstones in the south with abundant evaporites layers (Fig. 7). A significant tectonic shortening occurred in the western areas of northern Chile, and consequently, a remarkable increase in subsidence occurred in the Andean foredeep basin (Sempere et al., 1997; Jaillard et al., 2000). The sudden increase in subsidence is defined in the Potosí Basin by the accumulation of a thick sequence initiated with the deposition of the Aroifilla Formation in the Coniacian and followed by the Chaunaca, Torotoro and Coroma formations
(Jaillard and Sempere, 1991; Sempere, 1995; Sempere et al., 1997; Jaillard et al., 2000). At the same time, the deposition of the marine deposits of the Rio Azul Formation began in the Acre Basin (Cunha, 2007). In both basins, unconformities separate the Cenomanian-Turonian and Coniacian-Campanian successions (Sempere, 1995; Cunha, 2007). In the Coniacian, the arc migrated eastward in Peru together with the depocenter of the Andean Basin (Fig. 9) (Jaillard, 1994; Jaillard et al., 2000).

For the Parecis Basin, the exposition area of the Utiariti Formation might indicate that migration of its depocenter (Fig. 9), but there is insufficient data available to support this hypothesis. Similarly, there is no available information that allows reconstruction of the basin-fill geometry of the Alter do Chão Formation in the Solimões Basin. However, Caputo (1991) states that the Iquitos Arch between Acre and Solimões basins resulted from flexural uplift in response to orogenic loading of the Andes, and this structure migrated toward the Solimões Basin during its Cretaceous and Cenozoic sedimentation (Fig. 9).

In the northern Peruvian margin, an incipient thrusting and progressive emergence occurred in the early Santonian (Jaillard, 1994; Jaillard et al., 2000). However, in southern Peru and Bolivia, the stratigraphic data are insufficient to demonstrate the occurrence and duration of this event (Jaillard et al., 2000; Sempere et al., 1997), and it appears equally unrecorded in the Bauru Basin.

From the point of view of Sempere (1995), the latest Turonianearlier Coniacian orogenic pulse of the Peruvian Phase in Central Andes was followed by a stage of orogenic quiescence in Campanian, which is viewed in the Andean Basin as the decrease in the rate of sedimentation and progradation of immature sands from the west (Sempere, 1995). In the Bauru Basin, the fluvial 


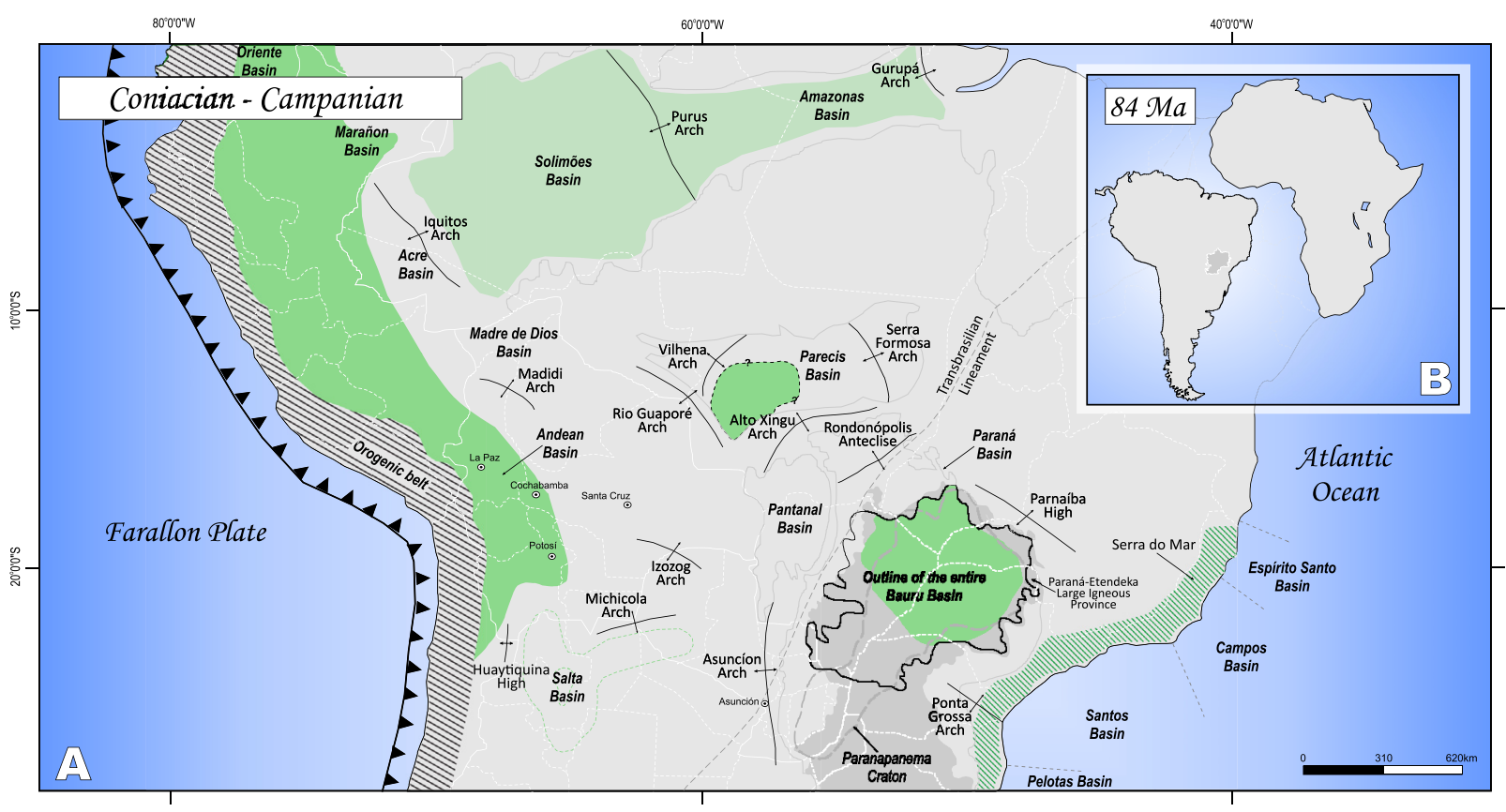

Estimated depositional areas during Coniacian-Campanian

Estimated depositional area of the Alter do Chão Formation during the Late Cretaceous

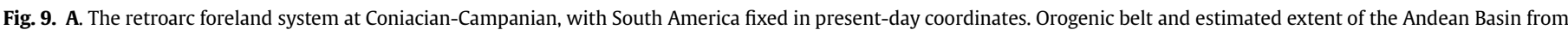

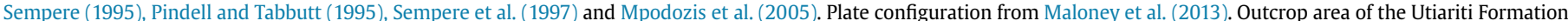

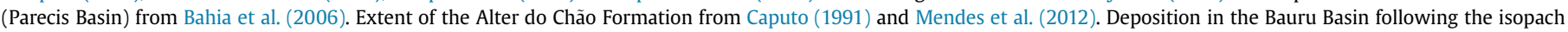

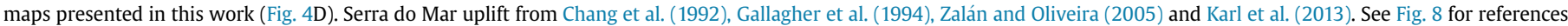
about structures. B. Relative position of South America and Africa at $84 \mathrm{Ma}$, with Africa fixed in present-day orientation (adapted from Nurnberg and Müller, 1991).

meandering deposits of the Adamantina Formation were deposited by the Campanian.

Similar to the Cenomanian-Turonian interval, no ConiacianCampanian sediment is preserved in the west of Bolivia and northwest of Paraguay, between the Andean Basin and the Bauru Basin (Figs. 7 and 9).

\subsubsection{End of sedimentation in the Bauru Basin - Maastrichtian to Paleogene}

After a relatively long interval of tectonic quiescence, a new contractional pulse of the Peruvian orogeny occurred in the late Campanian, with thrusting and uplift recorded in the Central Andes (Jaillard, 1994; Jaillard and Soler, 1996; Sempere et al., 1997; McQuarrie et al., 2005; Ramos, 2009). In the North Andes, accretion of oceanic crust occurred at 75-65 Ma along the Ecuadorian and Colombian margins, interpreted as multi-episodic collisions of the leading edge of the Caribbean Plateau with the South American Plate (Ramos, 1999, 2009; Ramos and Alemán, 2000). Moreover, in the Late Campanian, the location of the magmatic arc in northern Chile significantly shifted eastward, which has been interpreted as a decrease of the slab subduction angle (Jaillard and Soler, 1996; Jaillard et al., 2000). This latest Late Cretaceous shallowing of the subduction is also interpreted in the southern Central Andes and the South Andes (Ramos, 2009; Folguera et al., 2011; Spagnuolo et al., 2012).

The crustal loading event is represented in the Andean Basin by a high rate of subsidence near the Campanian-Maastrichtian boundary, which declined in the late Maastrichtian when the Maastrichtian-lower Paleocene sequence was deposited (Sempere, 1995; Jaillard and Soler, 1996; Sempere et al., 1997). In addition, the depocenter of the Andean Basin shifted eastward (Fig. 10) (Jaillard et al., 2000)

According to Sempere (1995), the sedimentation rate increased in the Potosí Basin near the Campanian-Maastrichtian boundary, and an influx of sand occurred from the west (Brazilian Shield), attributed to thrusting in the Andes accompanied by uplift of a forebulge in the west of Bolivia. A new cycle of marine transgression simultaneously occurred in the Andean Basin, extending southward to the Salta Basin. This transgression is characterized by the base of the El Molino Formation in the Potosí Basin and its equivalent Yacoraite Formation in the Salta Basin (Sempere, 1995; Gayet et al., 2001). In the Acre Basin, the Maastrichtian-Paleocene sequence is represented by the basal fluvial deposits of the Divisor Formation, the marine shales of the Rio Azul Formation (Fig. 7), and the marine transgressive facies of the Ramon Formation (Cunha, 2007). From the point of view of DeCelles and Horton (2003) and McQuarrie et al. (2005), the El Molino and Santa Lucía formations (Potosí Basin) might have been deposited in a backbulge province of a retroarc foreland system. Conversely, Sempere et al. (1997) propose that this Upper Cretaceous-Paleocene sequence was deposited in a foredeep basin, and Mpodozis et al. (2005) noted the ausence of a forebulge separating the Bolivian Potosí Basin from the deposits of the Purilactis Group close to the zone of active deformation.

During the Maastrichtian to Paleocene, the sedimentation in the studied area was markedly different from that of the preceding periods, with the preservation of the Cajones Formation in the area between the Andean Basin and the Bauru Basin (Figs. 7 and 10). An unconformity separates the Cajones Formation from the Jurassic extensional deposits below (Moretti et al., 1996). In the region of Santa Cruz in Bolivia, the Cajones Formation is interpreted as the product of fluvio-deltaic environment with a marine influence from the northwest and is laterally equivalent to the El Molino Formation (Kusiak and Zubieta Rossetti, 2003). The Cajones Formation is dated to the Maastrichtian based on fish fossils that also occur in the El Molino (Maastrichtian-Danian) and Yacoraite (Maastrichtian) 


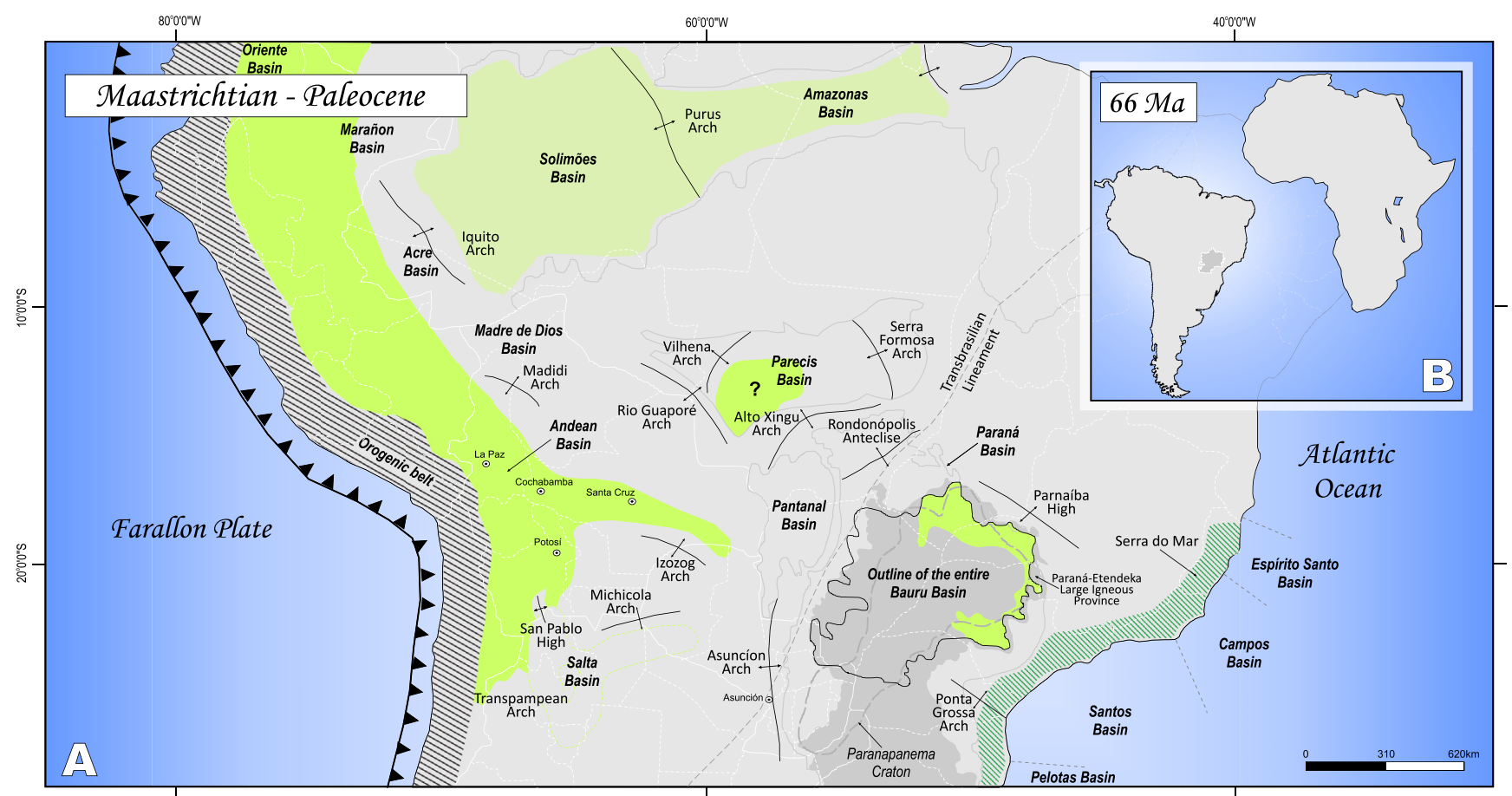

Estimated depositional areas during Maastrichtian-Paleocene

Estimated depositional area of the Alter do Chão Formation during the Late Cretaceous

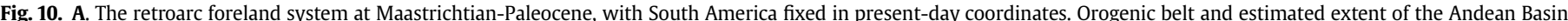

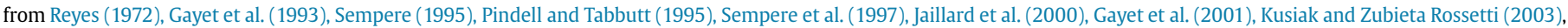

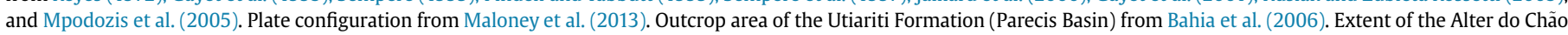

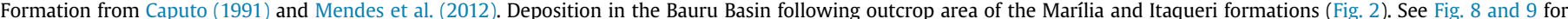
references about structures and Serra do Mar uplift. B. Relative position of South America and Africa at 66 Ma, with Africa fixed in present-day orientation (Scotese, 2001).

formations (Aguilera et al., 1989; Gayet et al., 2001; Kusiak and Zubieta Rossetti, 2003; Cónsole Gonella et al., 2009). The Adrián Jara Formation in northwest Paraguay corresponds to the Bolivian Cajones Formation (Gómez Duarte, 1986).

In the Parecis Basin, the age range of the Utiariti Formation extends to the early Paleocene (Bahia et al., 2006); but in the Solimões Basin, the upper limit of the Alter do Chão Formation is controversial (Dino et al., 1999).

According to Jaillard et al. (2000), widespread unconformities are recorded near the Maastrichtian-Paleocene boundary, with coarse sedimentation and deformation in the Central Andes suggesting that a tectonic event occurred by this time, but this possible event is still poorly known.

\subsubsection{The system during the Cenozoic}

The retroarc foreland system evolved during the Late Eocene to Miocene into the Chaco Basin (Fig. 1), with a Cenozoic sequence that is approximately $2.5 \mathrm{~km}$ thick, predominantly consisting of fluvial and lacustrine deposits (DeCelles and Horton, 2003). Its evolution is related to a clockwise rotation of the South American Plate in the Eocene and the orogenic pulses of the Incaic and Quechua tectonic phases (Mégard et al., 1984; Noblet et al., 1996; Jaillard and Soler, 1996).

A full discussion of the development of the system during the Cenozoic is beyond the scope of this contribution, which is focused on the depositional time of the Bauru Basin. The Cenozoic evolution has been intensively studied by many authors (i.e. Lamb et al., 1997; Horton and DeCelles, 1997; Jaillard et al., 2000; DeCelles and Horton, 2003; McQuarrie et al., 2005; Uba et al., 2006; Sempere et al., 1997; Jiménez et al., 2009; Prezzi et al., 2009; DeCelles et al., 2011; Maloney et al., 2013; Cohen et al., 2015; Engelder and
Pelletier, 2015; Quade et al., 2015). Certain studies have demonstrated that the system also migrated toward the craton during the Cenozoic, coupled with the eastward shift of the orogenic front and the development of the Eastern Cordillera (Horton and DeCelles, 1997; Jaillard et al., 2000; DeCelles and Horton, 2003; McQuarrie et al., 2005; Uba et al., 2006; Prezzi et al., 2009). Consequently, the Miocene deposits of the Pantanal Basin were deposited in the back-bulge province of the system and still constitute the backbulge of the modern foreland system (Horton and DeCelles, 1997; McQuarrie et al., 2005).

The thickness of the Pantanal basin-fill exceeds $400 \mathrm{~m}$ (Assine, 2003; Assine and Soares, 2004), which is not consistent with the thickness expected in back-bulge depozones (Horton and DeCelles, 1997; DeCelles and Giles, 1996). Therefore, additional mechanisms of subsidence have been considered to explain this thickness, including the dynamic effects of the subduction and isostatic effects of high-density rocks underlying the Pantanal Basin (Horton and DeCelles, 1997).

The Cenozoic sedimentation in Acre and Solimões basins has been associated with the Andean orogeny (Feijó and Cunha, 1994; Cunha, 2007; Cunha et al., 2007) and is characterized by fluvial meandering and lacustrine deposits of the Solimões Formation that reach $2200 \mathrm{~m}$ of thickness in the Acre Basin (Cunha, 2007) and $1800 \mathrm{~m}$ in the Solimões Basin (Wanderley Filho et al., 2007).

\section{Discussion}

The mechanisms of sediment accumulation and preservation in the Bauru Basin have been poorly understood. Integration of its characteristics (basin-fill geometry, thickness, depositional systems and age) with the available information on the overall tectonic 
setting and adjacent coexistent basins has aided in characterizing its subsidence pattern and has contradicted previous hypotheses.

The depositional systems in the Bauru Basin are nonmarine, and the caliber of sediment is predominantly fine. Local accumulations of coarse-grained sediments (alluvial fans) are limited to the Maastrichtian to early Paleocene portion of the succession in the north and east borders of the basin. As selected sedimentological studies previously noted (Soares et al., 1980; Paula e Silva et al., 2009), no evidence exists that faults controlled the initial sedimentation. Although the extensional regime that prevailed from the Jurassic to Early Cretaceous was responsible for widespread rifting in South America, the sedimentation in the Bauru Basin began in the Cenomanian with the Caiuá and Pirapozinho formations, as proposed herein. Hence, evidence was not found to support the preceding proposals of grabens and rifts.

Among the mechanisms that might potentially be important in basin development, the dynamic effects of plumes can be rejected as a basin-forming mechanism for the Bauru Basin. Previously, alkaline magmatism in structures near the border of the basin (Rondonópolis Anteclise, Paranaíba High and Asunción Arch) and the uplift of Serra do Mar were linked to the impact of the Trindade and Tristan da Cunha mantle plumes (Riccomini et al., 2005; Gibson et al., 1995; Van Decar et al., 1995; Brod et al., 2005; Zalán and Oliveira, 2005). Posteriorly, certain studies demonstrated a disconnection between the isotopic and geochemical compositions of the alkaline magmatic rocks and these plumes (Ruberti et al., 2005; Comin-Chiaramonti et al., 1997, 1999; Comin-Chiaramonti et al., 2014; Gomes et al., 2013). Moreover, paleomagnetic reconstructions have demonstrated that the Tristan da Cunha plume was located too far from the Paraná-Etendeka LIP at the time of its eruption (Valanginian), and the Trindade Plume was located approximately $1000 \mathrm{~km}$ to the north of Serra do Mar and Paranaíba High at the moment of the Late Cretaceous alkaline magmatism (Ernesto et al., 2002; Ernesto, 2005). These alkaline magmatic events could have resulted from decompressional melting due to local lithospheric extension and reactivation of normal pre-existing faults in the basement reactivated as transgressive structures related to the opening of the Atlantic Ocean (Almeida and Carneiro, 1998; Hasui and Haralyi, 1991). Consequently, alkaline magmatism adjacent to the Bauru Basin does not indicate that the basin was subjected to an extensional regime in Late Cretaceous and/or its subsidence related to mantle plumes. In addition, the uplift of these extrabasinal arches is not responsible for the basin subsidence, in opposition to previous hypotheses (i.e. Batezelli, 2015). The alkaline magmatic events are local occurrences in regions that were uplifted simultaneously with the sedimentation in Bauru Basin and might have acted as source areas of sediments.

Similarly, although the initial pulses of the Serra do Mar uplift were almost simultaneous with the beginning of the Coniacian sedimentation in Bauru Basin (Figs. 5 and 9), they do not have a direct relationship with its subsidence. For Chang et al. (1992) and Gallagher et al. (1994), the uplift of the Serra do Mar was caused by isostatic rebound due to unloading of the lithosphere during the rifting of South Atlantic, probably associated with underplating. This continental marginal uplift is deeply associated with the opening of the South Atlantic Ocean and cannot explain the creation of the Bauru Basin. During the climax of the Serra do Mar uplift, an expressive increase occurred in the sediment supply to the Santos Basin (Pereira e Feijó, 1994) and might have contributed similarly to the sedimentation of the Bauru Basin.

The Bauru Basin is positioned over the maximum preserved thickness of the basalts of the Paraná-Etendeka LIP or Serra Geral Formation (700-1000 m; Zalán et al., 1990) (Fig. 11). Therefore, certain authors have explained the Bauru Basin development as the result of thermal subsidence related to the cooling of these extensive and thick lava flows (Zalán et al., 1990) and/or a flexural depression created by the load of the basalts (Riccomini, 1997b; Fernandes and Coimbra, 1996, 2000; Milani, 2003; Milani and De Wit, 2008; Batezelli, 2015). Leng and Zhong (2010) demonstrated that surface subsidence occurs over tens of millions of years before food basalt eruptions in LIPs, and during the basalt eruption, the loading from erupted rocks causes subsidence at the periphery of the eruption area that affects the environment for subsequent episodes of basalt eruption.

In contrast, Mariani et al. (2013) suggested that underplated material might have been the mechanism that drove the subsidence of the Bauru Basin due to subcrustal loading and cooling. Indeed, magmatic underplating appears to be common in LIPs (Maclennan and Lovell, 2002; Thybo and Artemieva, 2013), but the existence of underplating beneath the Bauru Basin is still disputed (Molina et al., 1999; An and Assumpção, 2006; Mariani et al., 2013). Maclennan and Lovell (2002) have shown that the addition of mafic magma to the lithosphere causes surface uplift of approximately $10 \%$ of the thickness of the magma sill. Due to solidification of the magma, rapid subsidence occurs at an order of magnitude of approximately half of the original uplift, and additional relatively slow subsidence results from cooling of the solid lithosphere after magma injection (Maclenman and Lovell, 2002). According to Maclennan and Lovell (2002), the time scale of solidification is controlled by the sill thickness, but even considering the thickness of $10 \mathrm{~km}$ of the underplated material suggested by Mariani et al. (2013), the overall subsidence expected should be on the time scale of a few million years.

In both cases, loading from the erupted rocks or subcrustal loading and cooling of underplated material, these hypothesis should take in account that subsidence is expected to occur during or immediately after these events. Because the LIP extruded in the Valanginian (Thiede and Vasconcelos, 2010) and sedimentation in Bauru Basin is assumed to have started in Cenomanian, there is a time span of approximately 34 Ma between these hypothesized basin-forming mechanisms and the beginning of sedimentation.

The key aspects of the Bauru Basin are that the isopach pattern of the preserved entire basin-fill shows regional closure surrounding central thick zones (Fig. 4B), with accumulation in a shallow and broad region suggesting that the sediment accommodation could have involved a component of flexural subsidence. Furthermore, the isopach map of the interval from the Cenomanian to Turonian shows a depocenter in northwestern Paraná State (Fig. 4C), whereas the interval from the Coniacian to Campanian shows a depocenter in northwestern São Paulo State (Fig. 4D). This pattern can be explained as a migration of the depocenter though time and suggests an episodic history of creation of accommodation.

The stratigraphic architecture of the Bauru and Potosí basins are in phase, and both are out of phase with the region between them (Fig. 7). The tectonic load event at early Cenomanian led to subsidence and the establishment of marine and distal alluvial environments in the Andean Basin, e.g., as characterized by the upper portion of the Moa Formation in Acre Basin and the Miraflores Formation in Potosí Basin (Jaillard, 1994; Camoin et al., 1997; Martinez and Mamani, 1995; Jaillard and Sempere, 1991; Sempere, 1995; Sempere et al., 1997). The accumulation in the Bauru Basin began concomitantly with this Cenomanian transgression in the Andean Basin with the lacustrine, fluvial and eolic deposits of the Pirapozinho and Caiuá formations. A similar situation is observed during the second loading event in the early Coniacian (Peruvian Phase), starting with the deposition of the Rio Azul and Aroifilla formations, respectively, in Acre and Potosí basins, and the Araçatuba and Santo Anastácio formations in Bauru Basin. In both the Andean and Bauru basins, eastward shifts of their 

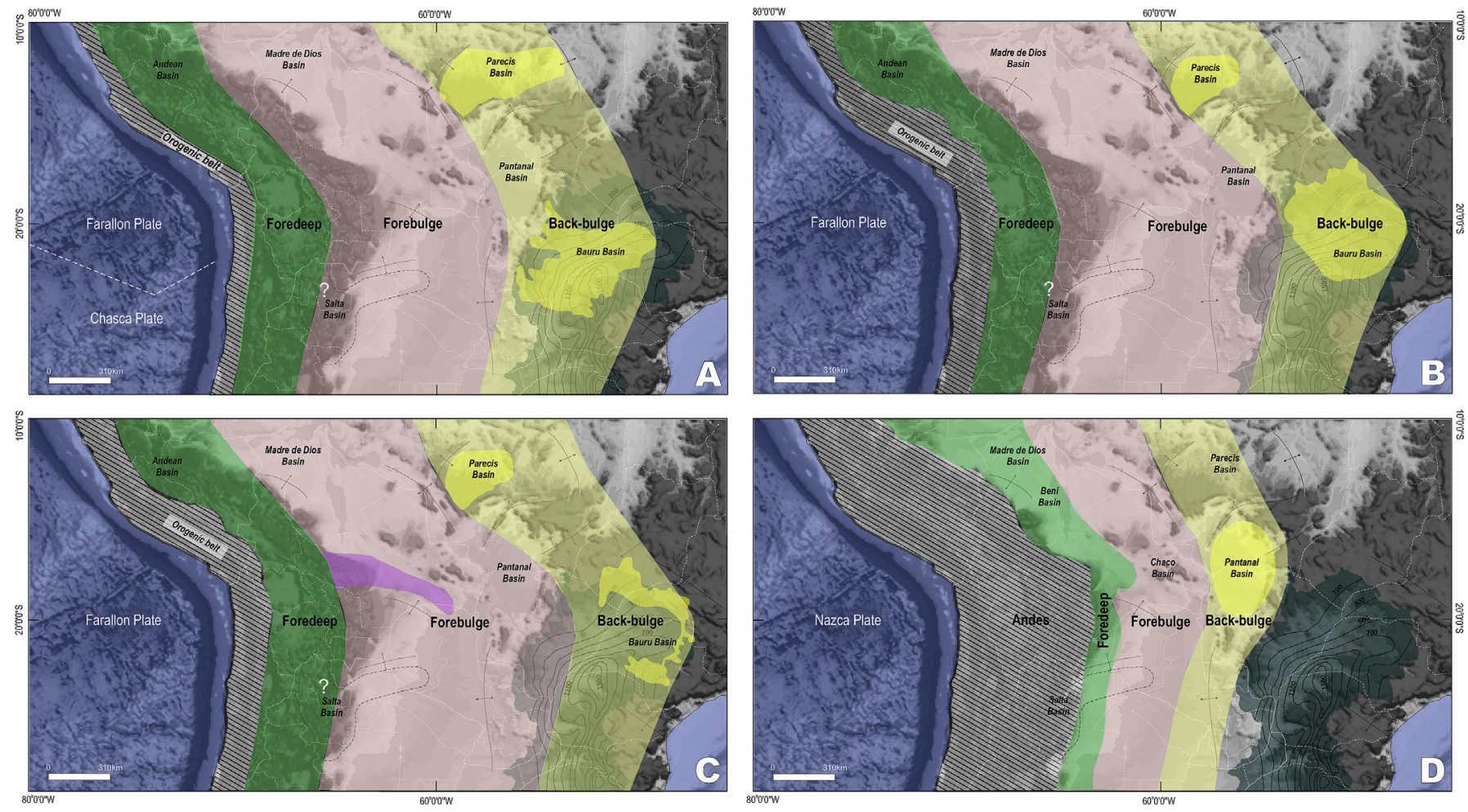

Preserved forebulge deposits

Preserved back-bulge deposits

Serra Geral Formation (Isolines are in kilometers)

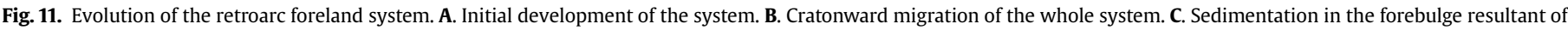

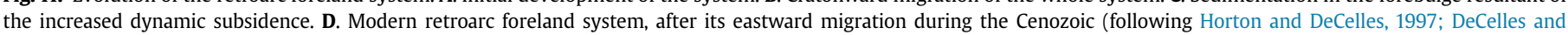

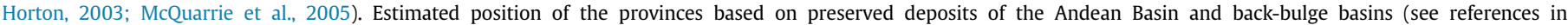
Figs. 8-10). Isopach map of the Serra Geral Formation from Zalán et al. (1990).

depocenters are observed (Fig. 9). Again, the load event in Late Campanian is responsible for the creation of accommodation in the Andean Basin (i.e., the Divisor and El Molino formations) following a new cratonward migration of the orogenic front and the associated shift of the basin depocenter (Sempere, 1995; Sempere et al., 1997). At the same time, there is an apparent shift of the Bauru depositional area, with the northwest onlap pattern of the Marília and Itaqueri formations onto the cratonic margin (Fig. 10). The simultaneous shifting of the Andean and Bauru basins in the same direction after orogenic events and their reciprocal stratigraphy are characteristics indicating that supracrustal loading was also responsible for the subsidence in Bauru Basin. From the shape, thickness and cratonward position of the Bauru Basin related to the foredeep Andean Basin and the Late Cretaceous orogen, it is deducible that the Bauru Basin has evolved in the back-bulge province of a retroarc foreland system (Figs. 2 and 11). Therefore, the Bauru sedimentary fill corresponds to a first-order sequence, with basal contact changing the tectonic setting, i.e., from the Mesozoic extensional deposits of the Paraná Basin below to the foreland system above.

The forebulge in retroarc foreland systems is an elevated feature, and therefore, it is generally considered to be a zone of nondeposition or erosion, and a resulting unconformity has been used to track its position trough time (DeCelles and Giles, 1996; Catuneanu, 2004). Consequently, the region in the west of Bolivia and northwest of Paraguay characterizes the forebulge depozone of this system, which has not received or preserved sediment from the Cenomanian to Campanian (Figs. 7-9).

Taking into account the extent of the foredeep Andean Basin, other contemporaneous deposits should be expected to exist along the cratonic side of the system, similar to the back-bulge Bauru Basin. Indeed, the position of the Upper Cretaceous deposits of the Parecis and Solimões basins appear to indicate that these basins evolved in the back-bulge province of this retroarc foreland system (Figs. 7 and 11). For Caputo (1991), the Iquitos Arch between the Acre and Solimões basins resulted from flexural uplift in response to the orogenic loading of the Andean belt during the Cretaceous. The progressive cratonward onlap of the foredeep strata of the Acre Basin onto an unconformity in the Iquitos Arc indicates that this structure underwent eastward migration coeval with the Cretaceous and Cenozoic sedimentation (Caputo, 1991). Therefore, the Iquitos Arch might be a forebulge between the foredeep Acre Basin and the back-bulge Solimões Basin. Still, there is no accurate biostratigraphy for the Upper Cretaceous deposits of the Parecis and Solimões basins due to the scarcity of fossil records, and there are insufficient data to reconstruct their basin-fill geometry. Therefore, the evidence is inconclusive for demonstration that they are back-bulge basins.

Certain authors interpreted the Cretaceous accumulation in Potosí Basin as resulting from thermal subsidence related to a rift system (Welsink et al., 1995; Camoin et al., 1997; Viramonte et al., 1999; Deconinck et al., 2000; Jiménez et al., 2009), similar to the nearby Salta rift system in northern Argentina. However, several authors have shown that at least a portion of the upper Puca Group (Aroifilla, Chaunaca, Torotoro, Coroma, El Molino and Santa Lucía formations) might represent a foreland basin related to initial shortening of the Andes (Sempere et al., 1997; Horton and DeCelles, 1997; DeCelles and Horton, 2003; McQuarrie et al., 2005). These authors suggested that the high rate of sediment accumulation, the variable rates of sedimentation through time and the abrupt 
cessation of sedimentation after the deposition of the Santa Lucía Formation are characteristics that differs from the expected gradual decrease of the subsidence rates predicted for rift models. In addition, the influence of the early Andean orogen on the Salta Group sedimentation in the Salta rift system remains unclear; it might not be initially controlled directly by the geodynamic process related to the orogenic belt (Salfity and Marquillas, 1994; Cominguez and Ramos, 1995; Hernandez et al., 1999; Masaferro et al., 2003; Marquillas et al., 2011; DeCelles et al., 2011; Siks and Horton, 2011; Becker et al., 2015). This research is consistent with the previous interpretations in which the Potosí Basin is a component of the foredeep Andean Basin.

The Cenomanian-early Paleocene South American retroarc foreland system is comparable with other systems in flexural profile, size, preserved thickness and pattern of depositional shift trough time, especially the Karoo and Western Canada basins, which are also formed on thick and Precambrian crusts with high flexural rigidity (Catuneanu et al., 1997b; Catuneanu et al., 1998; Miall et al., 2008). Along the dip, the relative proportion among the flexural provinces of the South American system is compatible with extant models and the proportions observed in the Karoo and Western Canada foreland systems (DeCelles and Giles, 1996; Catuneanu, 2004). The forebulge and the back-bulge are wider than the foredeep province (Figs. 6 and 11). The foredeep measures approximately a quarter of the wavelength, the forebulge is slightly longer than half of the wavelength, and the back-bulge is somewhat narrower than half of the wavelength. The flexural profile might be modified if the crust contains pre-existing weaknesses that allow the development of fault-controlled uplifts and depocenters (DeCelles and Giles, 1996; Catuneanu et al., 1997a, b). Accordingly, the slightly asymmetric flexural profile observed in the South American foreland system might be a consequence of heterogeneities of the basement.

The South American retroarc foreland system extends approximately $2005 \mathrm{~km}$ from the orogenic front, considering the preserved sedimentary fill of the interval from the Maastrichtian to Paleocene of the Bauru Basin (Fig. 11). Thus, the maximum size of this system along dip is wider than the North American Western Interior Foreland Basin with $865 \mathrm{~km}$ on the Western Canada Basin but is comparable with the Karoo retroarc foreland system. Although the back-bulge province of the Karoo system has not been completely understood, it is known that a portion of the sediments of this province is preserved in Tuli Basin, approximately $1550 \mathrm{~km}$ from the orogenic front (Catuneanu et al., 1998; Catuneanu et al., 2002; Bordy and Catuneanu, 2001; Catuneanu et al., 2005). Because the maximum extent of its foredeep reaches $415 \mathrm{~km}$ (Catuneanu et al., 1998), and this province represents a quarter of the wavelength of the sinusoidal flexural profile, the total extent of the Karoo system might be estimated at approximately $2075 \mathrm{~km}$. Wide retroarc foreland systems are developed in thicker, older or less deformed crust (high flexural rigidity or effective elastic thickness $\mathrm{Te}$ ) because the wavelength of the flexural profile depends primarily on the rheology and thickness of the underlying lithosphere (Beaumont, 1981; Watts, 1992; Catuneanu, 2004). Therefore, a wide system could be predictable for the South American case during the Late Cretaceous because this system was formed largely on thick and old crust with high Te (Figs. 1 and 6), including the Proterozoic-Archean Amazonian Craton (Cordani and Teixeira, 2007), the Neoproterozoic Paraguay Belt (Godoy et al., 2010), the Paleoproterozoic Paranapanema Craton (Mantovani et al., 2005; Ramos et al., 2010), and the Paleoproterozoic Rio Apa Block (Godoy et al., 2009; Faleiros et al., 2015).

A cratonward movement of the system is likely a response to the orogenic front shifting and redistribution of the load. The simultaneous shift of the depocenters of Bauru and Andean basins during times dominated by orogenic loading (Mochica and Peruvian phases) demonstrate that progradation of the South American retroarc foreland system occurred during its early stages in the Late Cretaceous, when the crust probably had a relatively higher rigidity. However, several authors have demonstrated that shifting occurred toward the craton during its later stages, as represented by the Chaco foreland system extending to the modern Pantanal Basin (Horton and DeCelles, 1997; DeCelles and Horton, 2003; McQuarrie et al., 2005). Flexural models predict that after successive loading events, the lithosphere relaxes stress, and with lower flexural rigidity, the system tends to be relatively smaller (Beaumont, 1981; Beaumont et al., 1988; Watts, 1992; Catuneanu, 2004). This condition explains the relatively shorter wavelength of the system observed in Cenozoic (Fig. 11), and a more significant progradation of the orogenic front occurred during this time of the Andean evolution.

The maximum preserved thickness $(271 \mathrm{~m})$ of the Bauru sedimentary fill is an order of magnitude greater than what would be expected if accommodation resulted only from flexural subsidence. Flexural models predict a subsidence on the order of $10 \mathrm{~m}$ for reasonably rigid continental lithosphere in back-bulge depozones (Beaumont, 1981; Allen and Allen, 2005; DeCelles and Giles, 1996). Nevertheless, several authors have documented accumulations of sediment in back-bulge depozones that range in thickness from tens of meters to more than $600 \mathrm{~m}$ (e.g. Plint et al., 1993; DeCelles and Currie, 1996; Holt and Stern, 1994; DeCelles and Giles, 1996; Leier et al., 2007). Thick accumulation have been explained by superimposed mechanisms, such as differential uplift and subsidence of basement blocks (Plint et al., 1993; Catuneanu et al., 1997a, b), dynamic subsidence and subcrustal loading (Holt and Stern, 1994). A key question is which set of variables controlled the widespread accommodation and thick sediment accumulation in the Bauru Basin.

First, mini-basins within the back-bulge province as well as the foreland system as a whole might have potentially been generated by differential subsidence and uplift associated with zones of weakness in the underlying crust, similar to the Western Canada Basin (Plint et al., 1993) and the Karoo foreland system (Catuneanu et al., 1997a, b). Therefore, in theory, the reactivation of crustal faults by the Cretaceous geodynamics could have been a mechanism overlapping the flexural subsidence of the Bauru Basin and might also have controlled its thickness.

Subcrustal loading processes can also act in the retroarc foreland system as a minor subsidence mechanism (Holt and Stern, 1994; Ingersoll, 2011; Allen et al., 2015). Thus, the subcrustal loading and cooling of underplating material suggested by Mariani et al. (2013) could be taken into account as an addition control on the Bauru accommodation. However, as discussed previously, the addition of mafic magma to the lower crust and uppermost mantle associated with the LIP is still uncertain, and the time span between this process and the beginning of the sedimentation should be better investigated.

Apparently, the forebulge was elevated above the base level during the Cenomanian to Campanian because there is no sediment with this age preserved in the west of Bolivia and northwest of Paraguay (Figs. 7 and 11). In the Maastrichtian, the dynamic subsidence might have been sufficiently high to outpace the flexural uplift of the forebulge and led to the preservation of fluvial-deltaic deposits in the forebulge province, the Cajones Formation in Bolivia and the Adrián Jara in Paraguay (Fig. 7). In the Santa Cruz region, a nonconformity separates the Jurassic extensional deposits below from the foreland deposits of the Cajones Formation above, and a northwest marine influence is recorded in the Cajones Formation (Kusiak and Zubieta Rossetti, 2003). However, the northwest marine incursions did not flood the entire foreland system because 
there is no evidence of marine paleodepositional environments in the back-bulge province. In fact, the rate of dynamic subsidence decreases exponentially from the subduction zone to the backbulge province (Fig. 6), tilting the entire flexural profile toward the orogen (Catuneanu, 2004; DeCelles et al., 2011), which explains the extent of the marine incursions only in the areas undergoing higher subsidence and preservation of the forebulge deposits in an area closer to the foredeep province. The active role of dynamic subsidence in the late Cretaceous is consistent with interpretations of shallowing of the subduction angle of the Farallon Plate at this time (i.e. Jaillard and Soler, 1996; Jaillard et al., 2000; Ramos, 2009; Folguera et al., 2011; Spagnuolo et al., 2012) because certain studies demonstrated that the dynamic loading by viscous mantle corner flow coupled to the subducting slab is more expressive if there is a shallow dipping slab as a result increasing dynamic subsidence (Mitrovica et al., 1989; Gurnis, 1992; Holt and Stern, 1994; Catuneanu et al., 1997a). Therefore, evidence exists of the action of dynamic subsidence in this foreland system, which also might have influenced the accommodation in Bauru Basin.

The South American plate shifted westward during the opening of the Atlantic Ocean (Figs. 8-10). The plate shows horizontal stress orientations nearly parallel to the direction of the absolute plate motion, indicating that the forces related to its motion are also responsible for the regional stress orientations (Allen and Allen, 1990; Assumpção, 1992). According to Cloetingh (1992), plates deform as they change latitude, and temporal fluctuations in stress are a natural consequence of the horizontal motions of the plates. It has been demonstrated that horizontal (in-plane) stress modifies the effects of existing vertical stresses on sedimentary basins, enlarging or reducing the amplitude of the resulting flexural deformation and simultaneously affecting several basins within a plate (Cloetingh et al., 1985; Miall, 2000). Indeed, in-plane stress is a minor mechanism in retroarc foreland basins (Allen and Allen, 1990; Ingersoll, 2011; Allen et al., 2015), and its superposition might amplify the primary driving mechanism; therefore, it might potentially act as another variable controlling the thickness of the Bauru deposits. This hypothesis is consistent with the idea addressed by Chang and Kowsmann (1996), who proposed that the region occupied by the Bauru Basin and other Cretaceous deposits (the Codó Formation in the Paraíba Basin and the Urucuia Group in the São Francisco Basin) were downwarped by the action of inplane stress associated with the change in stress regime in South America.

\section{Conclusions}

The Bauru Basin developed from the Cenomanian to early Paleocene in the back-bulge province of a retroarc foreland system that developed in response to Andean orogenic events. The characteristics discussed demonstrated that a supracrustal load was the main process acting in the Bauru Basin, but other subsidence mechanisms might have overlapped and accounted for its thickness.

The development of this foreland system should have influenced the evolution and geographic distribution of the coeval biota. Close similarities are noted among the paleobiota of the Bauru, Parecis and Potosí basins. Thus, the geodynamic events discussed in this contribution can be applied in future paleobiogeographic studies involving cycles of vicariance and geo-dispersal.

A differential orogenic loading along the strike might have generated a tilt in the direction of increased loading on the northwest of the system, which could have controlled the direction of the shoreline transgressions in the foredeep basin from northwestern South America and also might have controlled the differential thicknesses of the Andean Basin deposits along the strike.
The recognition of this Upper Cretaceous back-bulge deposit as a component of a retroarc foreland system in South America provides additional evidence that the Andean orogeny began in the Late Cretaceous. Moreover, the migration of the Bauru and the Andean basins can be viewed as an indicator of thrust-belt activity. This case study demonstrates that the increase in the rate of dynamic loading with time might be associated with the decrease of the subduction angle below the Andean margin, and the interaction between the supracrustal load and dynamic subsidence led to the lowering of the forebulge below the base level, generating accommodation at continental scales.

\section{Acknowledgments}

Financial support for this research was provided by Petrobras (Petróleo Brasileiro S.A.), CNPq (Science without Borders Program, process 242946/2013-5) and LEBAC (Laboratório de Estudo de Bacias, Universidade Estadual Paulista). Additional support was provided by the University of Alberta. We thanks DAEE (Departamento de Águas e Energia Elétrica of the São Paulo State Government) in the person of José Luiz Galvão de Mendonça for providing most of the well-log information employed in this research. Thanks to Rodrigo Prudente de Melo for the construction of the database and support to draw the isopach maps. We are grateful to Caio Fabrício Cezar Geroto for discussions on the record of Crocodylomorpha. In addition, we owe a debt of gratitude to Jefferson Cassu Manzano and Liliane Maia T. Manzano who has helped immensely in fieldwork, and Aparecido Andrade Buchner who immeasurably helped preparing the core samples.

\section{Appendix A. Supplementary data}

Supplementary data related to this article can be found at http:// dx.doi.org/10.1016/j.marpetgeo.2016.02.027.

\section{References cited in Supplementary Data}

Alaug et al., 2013, Almeida et al., 2004; Alvarenga and Nava, 2005; Araújo Júnior and Marinho, 2013; Archangelsky, 1994; Arid and Vizotto, 1966; Arratia et al., 2004; Azevedo et al., 2007; Azevedo et al., 2013; Báez and Petri, 1989; Bertini, 1996; Bertini and Franco-Rosas, 2001; Beu et al., 2014; Calvo et al., 2004; Campos et al., 2001; Campos et al., 2005; Campos et al., 2011; Candeiro et al., 2004; Candeiro et al., 2012a, 2012b; Carbonaro et al., 2013; Carvalho et al., 2004; Carvalho et al., 2005; Carvalho et al., 2007; Carvalho et al., 2011; Cione and Prasad, 2002; de la Fuente, 2003; Delcourt and Grillo, 2014; El Beialy et al., 2010; Fernandes and Basilici, 2009; Franco-Rosas, 2002; França and Langer, 2005; Gayet and Brito, 1989; Geroto and Bertini, 2012; Ghilardi et al., 2011; Hole et al., 1995; Hole et al., 2001; Iori and Carvalho, 2009; Iori and Garcia, 2012; Kellner and Azevedo, 1999; Kellner and Campos, 2000; Kellner et al., 2005; Kellner et al., 2006; Kellner et al., 2011a; Kellner et al., 2011b; Khand et al., 2000; Kischlat, 1994; Lio et al., 2015; Louterbach et al., 2014; Lu et al., 2006; Machado et al., 2008; Marconato, 2002; Marinho and Carvalho, 2009; Marinho et al., 2013; Martinelli and Forasiepi; 2004; Martinelli et al., 2012; Martinelli et al., 2013; Martinelli et al., 2015; Méndez et al., 2014; Mezzalira, 1989; Mezzalira and Simone, 1999; Morgan, 1978; Nascimento and Zaher, 2010; Neumann et al., 2003; Nobre and Carvalho, 2006; Novas et al., 2005; Ola-buraimo and Boboye, 2011; Olatunji, 2013; Otero et al., 2008; Pinheiro et al., 2008; Poyato-Ariza et al., 2000; Prezzi et al., 2014; Price, 1945; Price, 1950; Price, 1953; Price, 1955, Salgado and Carvalho, 2008; Santucci, 2008; Santucci and Bertini, 2006; Sereno et al., 2004; Sereno et al., 2008; Simone and Mezzalira, 1997; Suarez, 1969; Upchurch et al., 2004; Van 
Damme et al., 2015; Vullo et al., 2012; Wellnhofer and Buffetaut, 1999.

\section{References}

Aguilera, E., Solas, H., Peña, E., 1989. La Formacíon Cajones: Cretácico terminal del Subandino Central de Bolivia. Rev. Tec. YPFB 10 (3-4), 131-148.

Allen, P.A., Allen, J.A., 2005. Basin analysis: Principles and Applications, second ed. Blackwell Publishing Ltd.

Allen, P.A., Eriksson, P.G., Alkmim, F.F., Betts, P.G., Catuneanu, O., Mazumder, R. Meng, Q., Young, G.M., 2015. Classification of basins, with special reference to proterozoic examples. In: Mazumder, R., Eriksson, P.G. (Eds.), Precambrian Basins of India: Stratigraphic and Tectonic Context. Geological Society, London, 528.

Almeida, F.F.M., 1983. Relações tectônicas das rochas alcalinas mesozóicas da região meridional da plataforma Sul-Americana. Rev. Bras. Geociênc. 13, 139-158.

Almeida, F.F.M., Carneiro, C.D.R., 1998. Origem e evolução da Serra do Mar. Rev. Bras. Geociênc. 28 (2), 135-150.

Altınsaçlı, S., Altınsaçlı, S., Tombuloğlu, ş, 2004. The freshwater Ostracod Metacypris cordata Brady \& Robertson, 1870, new for Turkey. Zool. Middle East 32 (1), 118-120. http://dx.doi.org/10.1080/09397140.2004.10638056.

Alves, Y.M., Machado, L.P., Bergqvist, L.P., Brito, P.M., 2013. Redescription of two lungfish (Sarcopterygii: Dipnoi) tooth plates from the Late Cretaceous Bauru group, Brazil. Cretac. Res. 40, 243-250. http://dx.doi.org/10.1016/ j.cretres.2012.07.007.

An, M., Assumpção, M., 2006. Crustal and upper mantle structure in the intracratonic Paraná Basin, SE Brazil, from surface wave dispersion using genetic algorithms. J. S. Am. Earth Sci. 21 (3), 173-184. http://dx.doi.org/10.1016/j. jsames.2006.03.001.

Andrade, M.B., Bertini, R.J., 2008. A new Sphagesaurus (Mesoeucrocodylia: Notosuchia) from the upper Cretaceous of Monte Alto City (Bauru group, Brazil), and a revision of the Sphagesauridae. Hist. Biol. 20 (2), 101-136. http://dx.doi.org/ 10.1080/08912960701642949.

Assine, M.L., 2003. A bacia sedimentar do Pantanal mato-grossense. In: Mantesso Neto, V., Bartorelli, A., Carneiro, C.D.R., Brito-Neves, B.B. (Eds.), Geologia do Continente Sul-Americano - Evolução da Obra de Fernando Flávio Marques de Almeida. Beca, São Paulo, pp. 61-74.

Assine, M.L., Soares, P.C., 2004. Quaternary of the Pantanal, west-central Brazil. Quat. Int. 114 (1), 23-34. http://dx.doi.org/10.1016/S1040-6182(03)00039-9.

Assine, M.L., Piranha, J.M., Carneiro, C.D.R., 2003. Os paleodesertos Pirambóia e Botucatu. In: Mantesso Neto, V., Bartorelli, A., Carneiro, C.D.R., Brito-Neves, B.B. (Eds.), Geologia do Continente Sul-Americano - Evolução da Obra de Fernando Flávio Marques de Almeida. Beca, São Paulo, pp. 76-92.

Assumpção, M., 1992. The regional intraplate stress field in South America. J. Geophys. Res. 97 (B8), 11889-11903.

Assumpção, M., Feng, M., Tassara, A., Julià, J., 2013. Models of crustal thickness for South America from seismic refraction, receiver functions and surface wave tomography. Tectonophysics 609, 82-96. http://dx.doi.org/10.1016/j.tecto.2012. 11.014.

Báez, A.M., Gomez, R.O., Ribeiro, L.C.B., Martinelli, A.G., Teixeira, V.P.A., Ferraz, M.L.F., 2012. The diverse Cretaceous neobatrachian fauna of South America: Uberabatrachus carvalhoi, a new frog from the Maastrichtian Marilia formation, Minas Gerais, Brazil. Gondwana Res. 22 (3-4), 1141-1150. http://dx.doi.org/ 10.1016/j.gr.2012.02.021.

Bahia, R.B.C., Martins-Neto, M.A., Barbosa, M.S.C., Pedreira, A.J., 2006. Revisão estratigráfica da Bacia dos Parecis - Amazônia. Rev. Bras. Geociênc. 36 (4), 692-703.

Barcelos, J.H., Souza Filho, E.E., Fúlfaro, V.J., Landim, P.M.B., Cottas, L.R., Wu, F.T., Godoy, A.M., 1983. A Formação Itaqueri: um exemplo de tectonofácies. In: 4 Simpósio Regional de Geologia, São Paulo.

Batezelli, A., Saad, A.R., Etchebehere, M.L.C., Perinotto, J.A.J., Fúlfaro, V.J., 2003. Análise estratigráfica aplicada à Formação Araçatuba (Grupo Bauru - Ks) no Centro-Oeste do Estado de São Paulo. Geociências 22, 5-19.

Batezelli, A., Gomes, N.S., Perinotto, J.A.J., 2005. Petrografia e evolução diagenética dos arenitos da Porção Norte e Nordeste da Bacia Bauru (Cretáceo Superior). Rev. Bras. Geociênc. 35, 311-322.

Batezelli, A., Ladeira, F.S.B., Assine, M.L., 2014. Ambientes deposicionais e evolução estratigráfica do Cretáceo Superior da Bacia dos Parecis. Geociências 33 (3), 429-448.

Beaumont, C., 1981. Foreland basins. Geophys. J. R. Astron. Soc. 65 (2), 291-329. http://dx.doi.org/10.1111/j.1365-246X.1981.tb02715.x.

Becker, T.P., Summa, L.L., Ducea, M.N., Karner, G.D., 2015. Temporal growth of the Puna Plateau and its bearing on the post-salta rift system subsidence of the Andean foreland basin at $25^{\circ} 30^{\prime}$ S. In: DeCelles, P.G., Ducea, M.N., Carrapa, B., Kapp, P.A. (Eds.), Geodynamics of a Cordilleran Orogenic System: the Central Andes of Argentina and Northern Chile. Geological Society of America, Bolder, pp. 407-433.

Benson, R.B.J., Carrano, M.T., Brusatte, S.L., 2010. A new clade of archaic large bodied predatory dinosaurs (Theropoda: Allosauroidea) that survived to the latest Mesozoic. Naturwissenschaften 97, 71-78.

Bertels, A., 1972. Ostrácodos de agua dulce del miembro inferior de la Formación Huantrai-Co (Maastrichtiano inferior), provincia del Neuquén, República Argentina. Ameghiniana 9, 173-182.
Bertini, R.J., Marshall, L.G., Gayet, M., Brito, P., 1993. Vertebrate faunas from the Adamantina and Marília formations (Upper Baurú Group, late Cretaceous, Brazil) in their stratigraphic and paleobiogeographic context. Neues Jahrb. für Geol. Paläontol. 188 (1), 71-101.

Bertini, R.J., Santucci, R.M., Arruda-Campos, A.C., 1999. First occurrence of Aeolosaurus (Sauropoda, Titanosauridae) in Bauru group of the Paraná Basin, Brazil. In: 16 Congresso Brasileiro de Paleontologia, Crato.

Bittencourt, J.S., Langer, M.C., 2011. Mesozoic dinosaurs from Brazil and their biogeographic implications. An. Acad. Bras. Ciências 83 (1), 23-60.

Bizzi, L.A., Vidotti, R.M., 2003. Condicionamento do Magmatismo pós-Gondwana. In: Bizzi, L.A., Schobbenhaus, C., Vidotti, R.M., Gonçalves, J.H. (Eds.), Geologia, Tectônica e Recursos Minerais do Brasil. Serviço Geológico do Brasil - CPRM, Brasília, pp. 335-361.

Bonaparte, J.F., 1990. New Late Cretaceous mammals from the Los Alamitos formation, Northern Patagonia. Natl. Geogr. Res. 6, 63-93.

Bordy, E.M., Catuneanu, O., 2001. Sedimentology of the upper Karoo fluvial strata in the Tuli Basin, South Africa. J. Afr. Earth Sci. 33 (3-4), 605-629. http:// dx.doi.org/10.1016/S0899-5362(01)00090-2.

Brod, J.A., Barbosa, E.S.R., Junqueira-Brod, T.C., Gaspar, J.C., Diniz-Pinto, H.S. Sgarbi, P.B.A., Petrinovic, I.A., 2005. The Late-Cretaceous Goiás Alkaline province (GAP), Central Brazil. In: Comin-Chiaramonti, C., Gomes, C.B. (Eds.), Mesozoic to Cenozoic Alkaline Magmatism in the Brazilian Platform. Edusp/Fapesp, São Paulo, pp. 261-316.

Caetano-Chang, M.R., 1997. A Formação Pirambóia no centro-leste do Estado de São Paulo. Livre Docência, Instituto de Geociências e Ciências Exatas, Universidade Estadual Paulista.

Camoin, G., Casanova, J., Rouchy, J.M., BlancValleron, M.M., Deconinck, J.F., 1997. Environmental controls on perennial and ephemeral carbonate lakes: the central palaeo-Andean Basin of Bolivia during late Cretaceous to early Tertiary times. Sediment. Geol. 113 (1-2), 1-26. http://dx.doi.org/10.1016/S00370738(97)00052-3.

Candeiro, C.R.A., Nava, W.R., Martinelli, A.G., Forasiepi, A.M., Scanferla, C.A., Muzzopappa, P., 2009. New lizard record (Diapsida, Lepidosauria) from the upper Cretaceous Adamantina formation, Brazil. Bull. Geosci. 84 (3), 573-576. http://dx.doi.org/10.3140/bull.geosci.1101.

Caputo, M.V., 1991. Solimões megashear: intraplate tectonics in northwestern Brazil. Geology 19, 246-249.

Carignano, A.P., Varela, J.A., 2011. Ostrácodos (Crustacea) de la Formación Allen (Cretácico Tardío), Cuenca Neuquina, Argentina. Rev. Bras. Paleontol. 14 (2), 169-178.

Carvalho, I.S., Bertini, R.J., 1999. Mariliasuchus: um novo Crocodylornorpha (Notosuchia) do Cretaceo da Bacia Bauru, Brasil. Geol. Colomb. 24, 83-105.

Carvalho, I.S., Bertini, R.J., 2000. Contexto geológico dos notossuquíos (Crocodylomorpha) cretácicos do Brasil. Geol. Colomb. 25, 163-184.

Castro, J.C., Dias-Brito, D., Arai, M., Rodrigues, R., Musacchio, E.A., 2002. Formação São Carlos: uma nova unidade para o Grupo Bauru (Cretáceo continental do Brasil). In: 6 Simpósio sobre o Cretáceo do Brasil, Rio Claro.

Catuneanu, O., 2004. Retroarc foreland systems - evolution through time. J. Afr. Earth Sci. 38 (3), 225-242. http://dx.doi.org/10.1016/j.jafrearsci.2004.01.004.

Catuneanu, O., Beaumont, C., Waschbusch, P., 1997a. Interplay of static loads and subduction dynamics in foreland basins: reciprocal stratigraphies and the 'missing' peripheral bulge. Geology 25 (12), 1087-1090 doi: 10.1130/00917613(1997)025<1087:IOSLAS > 2.3.CO;2.

Catuneanu, O., Sweet, A.R., Miall, A.D., 1997b. Reciprocal architecture of Bearpaw TR sequences, uppermost Cretaceous, western Canada Sedimentary Basin. Bull. Can. Pet. Geol. 45 (1), 75-94.

Catuneanu, O., Hancox, P.J., Rubidge, B.S., 1998. Reciprocal flexural behaviour and contrasting stratigraphies: a new basin development model for the Karoo retroarc foreland system, South Africa. Basin Res. 10 (4), 417-439.

Catuneanu, O., Hancox, P.J., Cairncross, B., Rubidge, B.S., 2002. Foredeep submarine fans and forebulge deltas: orogenic off-loading in the underfilled Karoo Basin. J. Afr. Earth Sci. 35 (4), 489-502. http://dx.doi.org/10.1016/S0899-5362(02) 00154-9.

Catuneanu, O., Wopfner, H., Eriksson, P.G., Cairncross, B., Rubidge, B.S. Smith, R.M.H., Hancox, P.J., 2005. The Karoo basins of south-central Africa. J. Afr Earth Sci. 43 (1-3), 211-253. http://dx.doi.org/10.1016/j.jafrearsci.2005.07.007.

Chang, H.K., Kowsmann, R.O., 1996. The role of intraplate stress in the formation of Cretaceous interior basins of Brazil. In: 30th International Geological Congress, Beijing, China.

Chang, H.K., Kowsmann, R.O., Figueiredo, A.M.F., Bender, A.A., 1992. Tectonics and stratigraphy of the East Brazil Rift system: an overview. Tectonophysics 213 (1-2), 97-138. http://dx.doi.org/10.1016/0040-1951(92)90253-3.

Cloetingh, S., 1992. Intraplate stress and sedimentary basin evolution. In: Brown, G.C., Hawkesworth, C.J., Wilson, R.C.L. (Eds.), Understanding the Earth. Cambridge University Press, pp. 415-434.

Cloetingh, S., McQueen, H. Lambeck, K., 1985. On a tectonic mechanism for regional sealevel variations. Earth Planet. Sci. Lett. 75, 157-166.

Cohen, K.M., Finney, S.C., Gibbard, P.L., Fan, J.-X., 2013. The ICS international chronostratigraphic chart. updated Episodes 36, 199-204.

Cohen, A., McGlue, M.M., Ellis, G.S., Zani, H., Swarzenski, P.W., Assine, M.L., Silva, A., 2015. Lake formation, characteristics, and evolution in retroarc deposystems: a synthesis of the modern Andean orogen and its associated basins. In DeCelles, P.G., Ducea, M.N., Carrapa, B., Kapp, P.A. (Eds.), Geodynamics of a Cordilleran Orogenic System: the Central Andes of Argentina and Northern Chile. Geological Society of America, Boulder, pp. 309-335. 
Coimbra, A.M., 1976. Arenitos da Formação Bauru: estudo de áreas fonte. Master. Instituto de Geociências, Universidade de São Paulo.

Coimbra, A.M., Coutinho, J.M.V., Brandt Neto, M., Rocha, G.A., 1981. Lavas fonolíticas associadas à Formação Bauru no Estado de São Paulo. In: 3 Simpósio Regional de Geologia, Curitiba.

Colin, J.-P., Cabral, M.-C., Depeche, F., Mette, W., 2000. Sinuocythere n. gen. (Ostracoda, Limnocytheridae, Timiriaseviinae); a new genus of limnic ostracode from southern Tethyan middle and upper Jurassic. Micropaleontology 46 (2), 123-134.

Comin-Chiaramonti, P., Cundari, A., Piccirillo, E.M., Gomes, C.B., Castorina, F., Censi, P., De Min, A., Marzoli, A., Petrini, R., Speziale, S., Velázquez, V.F., 1997. Potassic and sodic igneous rocks from Eastern Paraguay: their origin from a lithospheric mantle andgenetic relationships with the associated Paraná flood tholeiites. J. Petrol. 38 (4), 495-528.

Comin-Chiaramonti, P., Cundari, A., DeGraff, J.M., Gomes, C.B., Piccirillo, E.M., 1999. Early Cretaceous-Tertiary magmatism in Eastern Paraguay (western Parana basin): geological, geophysical and geochemical relationships. J. Geodyn. 28 (4-5), 375-391. http://dx.doi.org/10.1016/S0264-3707(99)00016-2.

Comin-Chiaramonti, P., De Min, A., Girardi, V.A.V., Gomes, C.B., 2014. Carbonatites and primary carbonates in the Rio Apa and Amambay regions, NE Paraguay. Lithos 188, 84-96. http://dx.doi.org/10.1016/j.lithos.2013.10.027.

Comínguez, A.H., Ramos, V.A., 1995. Geometry and seismic expression of the Cretaceous Salta rift system, northwestern Argentina. In: Tankard, R. Soruco, Suárez, Welsink, H.J. (Eds.), Petroleum Basins of South America. American Association of Petroleum Geologists, pp. 325-340.

Cónsole Gonella, C.A., Cione, A.L., Aceñolaza, F.G., 2009. Registro del teleósteo Gasteroclupea branisai en la Formación Yacoraite (Maastrichtiano-Daniano) en elárea de Tres Cruces, Jujuy, Argentina. Tafonomía y correlación estratigráfica. Ser. Correl. Geol. 25, 129-138.

Cordani, U.G., Teixeira, W., 2007. Proterozoic accretionary belts in the Amazonian Craton. In: Hatcher Jr., R.D., Carlson, M.P., McBride, J.H., Martínez Catalán, J.R. (Eds.), 4-D Framework of Continental Crust. Geological Society of America, Bolder, pp. 297-320.

Coutinho, J.M.V. Coimbra, A.M., Brandt Neto, M., Rocha, G.A. 1982 Lavas alcalinas analcimíticas associadas ao Grupo Bauru (K-b) no Estado de São Paulo. In: 5 Congreso Latinoamericano de Geología, Buenos Aires.

Cunha, P.R.C., 2007. Bacia do Acre. Bol. Geociênc. Petrobras 15 (2), 207-215.

Cunha, P.R.C., Melo, J.H.G., Silva, O.B., 2007. Bacia do Amazonas. Bol. Geociênc. Petrobras 15 (2), 227-251.

Curto, J.B., Vidotti, R.M., Fuck, R.A., Blakely, R.J., Alvarenga, C.J.S., Dantas, E.L., 2014 The tectonic evolution of the Transbrasiliano Lineament in northern Parana Basin, Brazil, as inferred from aeromagnetic data. J. Geophys. Res. Solid Earth 119 (3), 1544-1562. http://dx.doi.org/10.1002/2013JB010593.

Daemon, R.F., Contreiras, C.J.A., 1971. Zoneamento palinológico da Bacia do Amazonas. In: 25 Congresso Brasileiro de Geologia São Paulo.

De Min, A., Piccirillo, E.M., Marzoli, A., Bellieni, G., Renne, P.R., Ernesto, M. Marques, L.S., 2003. The central atlantic magmatic province (CAMP) in Brazil petrology, geochemistry, 40Ar/39Ar ages, paleomagnetism and geodynamic implications. In: The Central Atlantic Magmatic Province: Insights from Fragments of Pangea. American Geophysical Union, pp. 91-128.

DeCelles, P.G., Currie, B.S., 1996. Long-term sediment accumulation in the middle Jurassic- early Eocene Cordilleran retroarc foreland-basin system. Geology 24 (7), 591-594.

DeCelles, P.G., Horton, B.K., 2003. Early to middle Tertiary foreland basin development and the history of Andean crustal shortening in Bolivia. Geol. Soc. Am. Bull. 115 (1), 58-77 doi: 10.1130/0016-7606(2003)115<0058:ETMTFB>2.0.CO;2.

DeCelles, P.G., Carrapa, B., Horton, B.K., Gehrels, G.E., 2011. Cenozoic foreland basin system in the central Andes of northwestern Argentina: implications for Andean geodynamics and modes of deformation. Tectonics 30. http://dx.doi.org/ 10.1029/2011TC002948.

Deconinck, J.F., Blanc-Valleron, M.M., Rouchy, J.M., Camoin, G., Badaut-Trauth, D. 2000. Palaeoenvironmental and diagenetic control of the mineralogy of upper Cretaceous-lower Tertiary deposits of the Central palaeo-Andean basin of Bolivia (Potosi area). Sediment. Geol. 132 (3-4), 263-278. http://dx.doi.org/10. 1016/S0037-0738(00)00035-X.

Dias, A.N.C., Tello, C.A.S., Chemale, F., de Godoy, M.C.T.F., Guadagnin, F., Iunes, P.J., Soares, C.J., Osorio, A.M.A., Bruckmann, M.P., 2011. Fission track and U-Pb in situ dating applied to detrital zircon from the Vale do Rio do Peixe formation, Bauru group, Brazil. J. S. Am. Earth Sci. 31 (2-3), 298-305. http://dx.doi.org/10.1016/ j.jsames.2011.02.003.

Dias-Brito, D., Musacchio, E.A., Castro, J.C., Maranhão, M.S.A.S., Suárez, J.M., Rodrigues, R. 2001. Grupo Bauru: uma unidade continental do Cretáceo no Brasil - concepções baseadas em dados micropaleontológicos, isotópicos e estratigráficos. Rev. Paléobiol. 20 (1), 245-304.

Dino, R., Silva, O.B., Abrahão, D., 1999. Caracterização palinológica e estratigráfica de estratos cretáceos da Formação Alter do Chão, Bacia do Amazonas. In: 5 Simpósio sobre o Cretáceo do Brasil Rio Claro.

Dino, R., Soares, E.A.A., Antonioli, L., Riccomini, C., Nogueira, A.C.R., 2012. Palynostratigraphy and sedimentary facies of middle Miocene fluvial deposits of the Amazonas Basin, Brazil. J. S. Am. Earth Sci. 34, 61-80. http://dx.doi.org/10.1016/ j.jsames.2011.11.008.

Engelder, T.M., Pelletier, J.D., 2015. Simulating foreland basin response to mountain belt kinematics and climate change in the Eastern Cordillera and Subandes: an analysis of the Chaco foreland basin in southern Bolivia. In: DeCelles, P.G., Ducea, M.N., Carrapa, B., Kapp, P.A. (Eds.), Geodynamics of a Cordilleran
Orogenic System: the Central Andes of Argentina and Northern Chile. Geological Society of America, Boulder, pp. 337-357.

Ernesto, M., 2005. Paleomagnetism of the post-paleozoic alkaline magmatism in the brazilian platform: questioning the mantle plume model. In: CominChiaramonti, P., Gomes, C.B. (Eds.), Mesozoic to Cenozoic Alkaline Magmatism in the Brazilian Platform. Edusp, São Paulo, pp. 689-705.

Ernesto, M., Marques, L.S., Piccirillo, E.M., Molina, E.C., Ussami, N., CominChiaramonti, P., Bellieni, G., 2002. Paraná Magmatic Province-Tristan da Cunha plume system: fixed versus mobile plume, petrogenetic considerations and alternative heat sources. J. Volcanol. Geotherm. Res. 118 (1-2), 15-36. http://dx. doi.org/10.1016/S0377-0273(02)00248-2.

Estes, R., Price, L.I., 1973. Iguanid lizard from the upper Cretaceous of Brazil. Science 180, 748-751.

Faleiros, F.M., Pavan, M., Remédio, M.J., Rodrigues, J.B., Almeida, V.V., Caltabeloti, F.P., Pinto, L.G.R., Oliveira, A.A., Pinto de Azevedo, E.J., Costa, V.S., 2015. Zircon U-Pb ages of rocks from the Rio Apa Cratonic Terrane (Mato Grosso do Sul, Brazil): new insights for its connection with the Amazonian Craton in pre-Gondwana times. Gondwana Research 0. http://dx.doi.org/10.1016/j.gr.2015.02.018.

Fariña, S., 2009. Proyecto para la Protección Ambiental y Desarrollo Sostenible del Sistema Acuífero Guaraní. In: Proyecto Acuífero Guaraní (Ed.), Asunción: República del Paraguay - Secretaría del Ambiente - Dirección General de Protección y Conservación de los Recursos Hídricos.

Feijó, F.J., Souza, R.G., 1994. Bacia do Acre. Bol. Geociênc. Petrobras 8 (1), 9-16.

Fernandes, L.A., Coimbra, A.M., 1992. A cobertura cretácea suprabasáltica no Estado do Paraná e Pontal do Paranapanema (SP): os grupos Bauru e Caiuá. In: 37 Congresso Brasileiro de Geologia, São Paulo.

Fernandes, L.A., Coimbra, A.M., 1996. A Bacia Bauru (Cretáceo Superior, Brasil). An. Acad. Bras. Ciências 68 (2), 195-205.

Fernandes, L.A., Coimbra, A.M., 2000. Revisão estratigráfica da parte Oriental da Bacia Bauru (Neo-Cretáceo). Rev. Bras. Geociênc. 30 (4), 717-728.

Fernandes, L.A., Ribeiro, C.M.M., 2015. Evolution and palaeoenvironment of the Bauru Basin (upper Cretaceous, Brazil). J. S. Am. Earth Sci. 61, 71-90. http://dx. doi.org/10.1016/j.jsames.2014.11.007.

Fernandes, P., Rodrigues, B., Borges, M., Matos, V., Clayton, G., 2013. Organic maturation of the Algarve Basin (southern Portugal) and its bearing on thermal history and hydrocarbon exploration. Mar. Pet. Geol. 46 (0), 210-233. http://dx. doi.org/10.1016/j.marpetgeo.2013.06.015.

Filippi, L.S., Martinelli, A.G., Garrido, A.C., 2013. Registro de un dinosaurio Aeolosaurini (Sauropoda, Titanosauria) en el Cretácico Superior (Formación Plottier) del norte de la Provincia de Neuquén, Argentina, y comentarios sobre los Aeolosaurini sudamericanos. Rev. Bras. Paleontol. 16 (1), 147-156.

Folguera, A., Orts, D., Spagnuolo, M., Vera, E.R., Litvak, V., Sagripanti, L., Ramos, M.E., Ramos, V.A., 2011. A review of late Cretaceous to Quaternary palaeogeography of the southern Andes. Biol. J. Linn. Soc. 103 (2), 250-268. http://dx.doi.org/ $10.1111 / j .1095-8312.2011 .01687 . x$

Franco-Rosas, A.C., Salgado, L., Rosas, C.F., Carvalho, I.S., 2004. Nuevos materiales de titanosaurios (Sauropoda) em el Cretácico Superior de Mato Grosso, Brasil. Rev. Bras. Paleontol. 7, 329-336.

Fúlfaro, V.J., 1996. Geología del Paraguay Oriental. In: Comin-Chiaramonti, P., Gomes, C.B. (Eds.), Magmatismo Alcalino en Paraguay Central-Oriental Relaciones con Magmatismo Coeval en Brasil. Edusp/Fapesp, São Paulo, pp. 11-29.

Fúlfaro, V.J., Barcelos, J.H., 1991. Grupo Bauru no Triângulo Mineiro: uma nova visão litoestratigráfica. In: 2 Simpósio de Geologia do Sudeste, São Paulo.

Fúlfaro, V.J., Barcelos, J.H., 1993. Fase rifte na Bacia Sedimentar do Paraná: a Formação Caiuá. Geociências 12 (1), 33-45.

Fúlfaro, V.J., Perinotto, J.A.J., 1996. A Bacia Bauru: Estado da Arte. In: 4 Simpósio sobre o Cretáceo do Brasil, Rio Claro.

Fúlfaro, V.J., Etchebehere, M.L.C., Perinotto, J.A.J., Saad, A.R., 1999. Santo Anastácio: um geossolo cretácico na Bacia Caiuá. In: 5 Simpósio sobre o Cretáceo do Brasil, Serra Negra.

Gaffney, E.S., Meylan, P.A., Wood, R.C., Simons, E., Campos, D.D., 2011. Evolution of the Side-necked Turtles: the family Podocnemididae. Bull. Am. Mus. Nat. Hist. 350, 1-237.

Gallagher, K., Hawkesworth, C.J., Mantovani, M.S.M., 1994. The denudation history of the onshore continental margin of SE Brazil inferred from apatite fission track data. J. Geophys. Res. Solid Earth 99 (B9), 18117-18145. http://dx.doi.org/ 10.1029/94JB00661.

Gayet, M., Sempre, T., Cappetta, H., Jaillard, E., Lévy, A., 1993. La présence de fossiles marins dans le Crétacé terminal des Andes centrales et ses conséquences paléogéographiques. Palaeogeogr. Palaeoclimatol. Palaeoecol. 102 (3-4), 283-319. http://dx.doi.org/10.1016/0031-0182(93)90072-Q.

Gayet, M., Marshall, L.G., Sempere, T., Meunier, F.J., Cappetta, H., Rage, J.C., 2001 Middle Maastrichtian vertebrates (fishes, amphibians, dinosaurs and other reptiles, mammals) from Pajcha Pata (Bolivia). Biostratigraphic, palaeoecologic and palaeobiogeographic implications. Palaeogeogr. Palaeoclimatol. Palaeoecol. 169 (1-2), 39-68. http://dx.doi.org/10.1016/S0031-0182(01)00214-0.

Gibson, S.A., Thompson, R.N., Leonardos, O.H., Dickin, A.P., Mitchell, J.G., 1995. The late Cretaceous impact of the Trindade mantle plume: evidence from largevolume, mafic, potassicmagmatism in SE Brazil. J. Petrol. 36, 189-229.

Gobbo-Rodrigues, S.R., Petri, S., Bertini, R.J., 1999a. Ocorrências de ostrácodes na Formação Adamantina do Grupo Bauru, Cretáceo Superior da Bacia do Paraná e possibilidades de correlação com depósitos isócronos argentinos. Parte I Família Ilyocyprididae. Acta Geol. Leopoldensia 23 (49), 3-13.

Gobbo-Rodrigues, S.R., Petri, S., Bertini, R.J., 1999b. "Ocorrências de ostrácodes na Formação Adamantina do Grupo Bauru, Cretáceo Superior da Bacia do Paraná e 
possibilidades de correlação com depósitos isócronos argentinos. Parte II Família Limnocytheridae. Rev. Univ. Guarulhos - Geociênc. 6 (6), 5-11.

Godoy, A.M., Manzano, J.C., Araújo, L.M.B., Silva, J.A., 2009. Contexto geológico e estrutural do Maciço Rio Apa, sul do Cráton Amazônico - MS. Geociências 28 (4), 485-499.

Godoy, A.M., Pinho, F.E.C., Manzano, J.C., Araújo, L.M.B., Jesué Antonio da Silva, J.A. Figueiredo, M., 2010. Estudos isotópicos das rochas granitóides neoproterozóicas da Faixa de Dobramento Paraguai. Rev. Bras. Geociênc. 40 (3), 380-391.

Godoy, P.L., Montefeltro, F.C., Norell, M.A., Langer, M.C., 2014. An additional Baurusuchid from the Cretaceous of Brazil with evidence of interspecific predation among crocodyliformes. PLoS One 9 (5). http://dx.doi.org/10.1371/ journal.pone.0097138.

Gomes, C.B., Valarelli, J.V., 1970. Nova ocorrência de rochas alcalinas no Estado de São Paulo. In: 24 Congresso Brasileiro de Geologia, Brasília.

Gomes, C.B., Comin-Chiaramonti, P., Velázquez, V.F., 2013. A synthesis on the alkaline magmatism of Eastern Paraguay. Braz. J. Geol. 43, 745-761.

Gómez Duarte, D., 1986. Contribución al conocimiento de la geología del norte del Chaco paraguayo. In: Ministerio de Obras Públicas y Comunicaciones. Republica del Paraguay, Lagerenza.

Grambast, L., Gutiérrez, G., 1977. Espèces nouvelles de charophytes du Crétacé supérieur terminal de la Province de Cuenca (Espagne). Paléobiol. Cont. 8, 1-34.

Gravina, E.G., Kafino, C.V., Brod, J.A., Boaventura, G.R., Santos, R.V., Guimaraes, E.M. Jost, H., 2002. Proveniência de arenitos das formações Uberaba e Marília (Grupo Bauru) e do Garimpo do Bandeira: implicações para a controvérsia sobre a fonte do diamante do Triângulo Mineiro. Rev. Bras. Geociênc. 32 (4), 545-558.

Gurnis, M., 1992. Rapid continental subsidence following the initiation and evolution of subduction. Science 255 (5051), 1556-1558. http://dx.doi.org/10.2307/ 2876776.

Hasui, Y., 1968. Formação Uberaba. In: 22 Congresso Brasileiro de Geologia, Belo Horizonte.

Hasui, Y., Haralyi, N.L.E., 1991. Aspectos lito-estruturais e geofísicos do soerguimento do Alto Paranaíba. Geociências 10, 57-77.

Heine, C., Zoethout, J., Muller, R.D., 2013. Kinematics of the south Atlantic rift. Solid Earth 4 (2), 215-253. http://dx.doi.org/10.5194/se-4-215-2013.

Hernández, R., Disalvo, A., Boll, A., Gómez Omil, R., 1999. Estratigrafía secuencial del Grupo Salta, con énfasis en las subcuencas de Metán-Alemania, Noroeste Argentino. In: $14^{\circ}$ Congreso Geológico Argentino, Salta.

Holt, W.E., Stern, T.A., 1994. Subduction, platform subsidence, and foreland thrust loading: the late Tertiary development of Taranaki Basin, New Zealand. Tectonics 13 (5), 1068-1092. http://dx.doi.org/10.1029/94TC00454.

Horton, B.K., DeCelles, P.G., 1997. The modern foreland basin system adjacent to the Central Andes. Geology 25 (10), 895-898 doi: 10.1130/0091-7613(1997) 025<0895:TMFBSA > 2.3.CO;2.

Iori, F.V., Carvalho, I.S., 2011. Caipirasuchus paulistanus, a new sphagesaurid (Crocodylomorpha, Mesoeucrocodylia) from the Adamantina formation (upper Cretaceous, Turonian-Santonian), Bauru Basin, Brazil. J. Vertebr. Paleontol. 31 (6), 1255-1264. http://dx.doi.org/10.1080/02724634.2011.602777.

Jaillard, E., 1994. Kimmeridgian to Paleocene tectonic and geodynamic evolution of the Peruvian (and Ecuadorian) margin. In: Salfity, J.A. (Ed.), Cretaceous Tectonics in the Andes. Fried. Vieweg \& Sohn, Braunschweig/Wiesbaden, pp. 101-167.

Jaillard, E., Sempere, T., 1991. Las secuencias sedimentarias de la Formacion Miraflores y su significado cronoestratigrafico. Rev. Técnica YPFB 12 (2), 257-264.

Jaillard, E., Soler, P., 1996. Cretaceous to early Paleogene tectonic evolution of the northern Central Andes $\left(0-18^{\circ} \mathrm{S}\right)$ and its relations to geodynamics. Tectonophysics 259 (1-3), 41-53. http://dx.doi.org/10.1016/0040-1951(95)00107-7.

Jaillard, E., Cappetta, H., Ellenberger, P., Feist, M., Grambast-Fessard, N., Lefranc, J.P., Sige, B., 1993. Sedimentology, paleontology, biostratigraphy and correlation of the late Cretaceous vilquechico group of the Southern Peru. Cretac. Res. 14 (6), 623-661. http://dx.doi.org/10.1006/cres.1993.1044.

Jaillard, E., Feist, M., Grambast-Fessard, N., Carlotto, V., 1994. Senonian-Paleocene charophyte succession of the Peruvian Andes. Cretac. Res. 15, 445-456.

Jaillard, E., Hérail, G., Monfret, T., Díaz-Martínez, E., Baby, P., Lavenu, A., Dumont, J.F., 2000. Tectonic evolution of the Andes of Ecuador, Peru, Bolivia and Northernmost Chile. In: Cordani, U.G., Milani, E.J., Thomaz Filho, A., Campos, D.A. (Eds.), Tectonic Evolution of South America, pp. 481-558. Rio de Janeiro: 31st Internation Geological Congress.

Jaimes, E., Freitas, M., 2006. An Albian-Cenomanian unconformity in the northern Andes: evidence and tectonic significance. J. S. Am. Earth Sci. 21 (4), 466-492. http://dx.doi.org/10.1016/j.jsames.2006.07.011.

Jiménez, N., López-Velásquez, S., Santiváñez, R., 2009. Evolución Tectonomagmática de los Andes Bolivianos. Rev. la Asoc. Geol. Argent. 65 (1), 36-67.

Karl, M., Glasmacher, U.A., Kollenz, S., Franco-Magalhaes, A.O.B., Stockli, D.F., Hackspacher, P.C., 2013. Evolution of the South Atlantic passive continental margin in southern Brazil derived from zircon and apatite (U-Th-Sm)/He and fission-track data. Tectonophysics 604, 224-244. http://dx.doi.org/10.1016/j. tecto.2013.06.017.

Kellner, A.W.A., Campos, D.A., 2002. On a theropod dinosaur (Abelisauria) from the continental Cretaceous of Brazil. Arq. do Mus. Nac. 60 (3), 163-170.

Kellner, A.W.A., Campos, D.A., 2007. Short note on the Ingroup relationships of the Tapejaridae (Pterosauria, Pterodactyloidea). Bol. do Mus. Nac. 75, 1-14.

Kusiak, M., Zubieta Rossetti, D., 2003. Cajones formation geometry and regional facies distribution in The Boomerang Hills Area, Bolivia. In: 8th Simposio Bolivariano - Exploracion Petrolera en las Cuencas Subandinas Bogotá.
Ladeira, F.S.B., Santos, M., 2005. O uso de paleossolos e perfís de alteração para a identificação e análise de superfícies geomórficas regionais: o caso da Serra de Itaqueri (SP). Rev. Bras. Geomorfol. 6 (2), 3-20.

Lamb, S., Hoke, L., Kennan, L., Dewey, J., 1997. Cenozoic evolution of the Centra Andes in Bolivia and northern Chile. In: Burg, J.-P., Ford, M. (Eds.), Orogeny through Time. Geological Society, London.

Leier, A.L., DeCelles, P.G., Kapp, P., Ding, L., 2007. The takena formation of the Lhasa terrane, southern Tibet: the record of a late Cretaceous retroarc foreland basin. Geol. Soc. Am. Bull. 119 (1-2), 31-48. http://dx.doi.org/10.1130/B25974.1.

Lima, M.R., Mezallira, S., Dino, R., Saad, A.R., 1986. Descoberta de microflora em sedimentos do Grupo Bauru, Cretáceo do Estado de São Paulo. Rev. do Inst. Geociênc. 7 (1/2), 5-9.

Lopes, R.P., Buchmann, F.S.C., 2008. Fossils of titanosaurs (Dinosauria, Sauropoda) from a new outcrop in Triângulo Mineiro, Southeastern Brazil. Rev. Bras. Paleontol. 11 (1), 69-72.

Machado, E.B., Avilla, L.D., Nava, W.R., Campos, D.D., Kellner, A.W.A., 2013a. A new titanosaur sauropod from the late Cretaceous of Brazil. Zootaxa 3701 (3) $301-321$.

Machado, E.B., Campos, D.A., Calvo, J.O., Kellner, A.W.A., 2013b. A new Abelisauroid from the upper Cretaceous of Brazil. Rev. Mex. Ciencias Geol. 30 (2), 446-452.

Maclennan, J., Lovell, B., 2002. Control of regional sea level by surface uplift and subsidence caused by magmatic underplating of Earth's crust. Geology 30 (8), 675-678.

Maloney, K.T., Clarke, G.L., Klepeis, K.A., Quevedo, L., 2013. The Late Jurassic to present evolution of the Andean margin: drivers and the geological record. Tectonics 32 (5), 1049-1065. http://dx.doi.org/10.1002/tect.20067.

Mantovani, M.S.M., Quintas, M.C.L., Shukowsky, W., Brito Neves, B.B., 2005. Delimitation of the Paranapanema Proterozoic block: a geophysical contribution. Episodes 28 (1), 18-22.

Manzig, P.C., Kellner, A.W.A., Weinschutz, L.C., Fragoso, C.E., Vega, C.S Guimaraes, G.B., Godoy, L.C., Liccardo, A., Ricetti, J.H.Z., Moura, C.C., 2014. Discovery of a rare pterosaur Bone Bed in a Cretaceous desert with insights on ontogeny and Behavior of flying reptiles. PLoS One 9 (8). http://dx.doi.org/ 10.1371/journal.pone.0100005.

Mariani, P., Braitenberg, C., Ussami, N., 2013. Explaining the thick crust in Parana basin, Brazil, with satellite GOCE gravity observations. J. S. Am. Earth Sci. 45 , 209-223. http://dx.doi.org/10.1016/j.jsames.2013.03.008.

Marquillas, R.A., del Papa, C., Sabino, I.F., 2005. Sedimentary aspects and paleoenvironmental evolution of a rift basin: Salta Group (Cretaceous-Paleogene), northwestern Argentina. Int. J. Earth Sci. 94 http://dx.doi.org/10.1007/s00531004-0443-2.

Marquillas, R.A., Salfity, J.A., Matthews, S.J., Matteini, M., Dantas, E., 2011. U-Pb zircon age of the Yacoraite formation and its significance to the CretaceousTertiary boundary in the Salta basin, Argentina. In: Salfity, J.A., Marquillas, R.A. (Eds.), Cenozoic Geology of the Central Andes of Argentina. SCS Publisher, Salta, pp. 227-246.

Marshall, L.G., De Muizon, C., Sigé, B., 1983. Late Cretaceous mammals (Marsupialia) from Bolivia. Geobios 16 (6), 739-745.

Martinelli, A.G., Garrido, A.C., Forasiepi, A.M., Paz, E.R., Gurovich, Y., 2007. Notes on fossil remains from the early Cretaceous Lohan Cura formation, Neuquén province, Argentina. Gondwana Res. 11 (4), 537-552. http://dx.doi.org/10.1016 | j.gr.2006.07.007.

Martinelli, A.G., Riff, D., Lopes, R.P., 2011. Discussion about the occurrence of the genus Aeolosaurus Powell 1987 (Dinosauria, Titanosauria) in the upper Cretaceous of Brazil. Gaea - J. Geosci. 7 (1), 34-40. http://dx.doi.org/10.4013/ gaea.2011.71.03.

Martinelli, A.G., Bogan, S., Agnolin, F.L., Ribeiro, L.C.B., Cavellani, C.L., Ferraz, M.L.F., Teixeira, V.P.A., 2013. First fossil record of amiid fishes (Halecomorphi, Amiiformes, Amiidae) from the late Cretaceous of Uberaba, Minas Gerais State, Brazil. Alcheringa 37 (1), 105-113. http://dx.doi.org/10.1080/ 03115518.2012.709444.

Martinez, E.D., Mamani, N.C., 1995. Paleozoico Superior y Cretacico del area de Huaranca (Sapahaqui - Rio La Paz), Cordillera Oriental de Bolivia. Rev. Técnica YPFB 16 (1-2), 161-167.

Marzoli, A., Renne, P.R., Piccirillo, E.M., Ernesto, M., Bellieni, G., De Min, A., 1999. Extensive 200-million-year-old continental flood basalts of the Central Atlantic magmatic province. Science 284, 616-619.

Masaferro, J.L., Bulnes, M., Poblet, J., Casson, N., 2003. Kinematic evolution and fracture prediction of the Valle Morado structure inferred from 3D seismic data, Salta province, northwest Argentina. AAPG Bull. 87 (7), 1083-1104.

McQuarrie, N., Horton, B.K., Zandt, G., Beck, S., DeCelles, P.G., 2005. Lithospheric evolution of the Andean fold-thrust belt, Bolivia, and the origin of the central Andean plateau. Tectonophysics 399 (1-4), 15-37. http://dx.doi.org/10.1016/j. tecto.2004.12.013.

Mégard, F., 1984. The Andean orogenic period and its major structures in central and northern Peru. J. Geol. Soc. 141 (5), 893-900.

Mégard, F., Noble, D.C., McKee, E.H., Bellon, H., 1984. Multiple pulses of Neogene compressive deformation in the Ayacucho intermontane basin, Andes of centra Peru. Geol. Soc. Am. Bull. 95 (9), 1108-1117.

Mendes, A.C., Truckenbrod, W., Nogueira, A.C.R., 2012. Análise faciológica da Formação Alter do Chão (Cretáceo, Bacia do Amazonas), próximo à cidade de Óbidos, Pará, Brasil. Rev. Bras. Geociênc. 42 (1), 39-57.

Méndez, A.H., Novas, F.E., Iori, F.V., 2012. First record of Megaraptora (Theropoda, Neovenatoridae) from Brazil. Comptes Rendus Palevol 11 (4), 251-256. http:// dx.doi.org/10.1016/j.crpv.2011.12.007. 
Menegazzo, M.C., Bertini, R.J., Manzini, F.F., 2015. A new turtle from the upper Cretaceous Bauru group of Brazil, updated phylogeny and implications for age of the Santo Anastacio formation. J. S. Am. Earth Sci. 58, 18-32. http:/ dx.doi.org/10.1016/j.jsames.2014.12.008.

Mezzalira, S., 1974. Contribuição ao conhecimento da estratigrafia e paleontologia do arenito Bauru, Boletim 51. Instituto Geográfico e Geológico, São Paulo.

Miall, A.D., 2000. Principles of Sedimentary Basin Analysis, third ed. Springer-Verlag, Heidelberg.

Miall, A.D., Catuneanu, O., Vakarelov, B., Post, R., 2008. The western interior basin. In: Miall, A.D. (Ed.), The Sedimentary Basins of the United States and Canada. Elsevier, Amsterdam, pp. 329-362.

Milani, E.J., 2003. Comentários sobre a origem e a evolução tectônica da Bacia do Paraná. In: Mantesso Neto, V., Bartorelli, A., Carneiro, C.D.R., Brito-Neves, B.B. (Eds.), Geologia do Continente Sul-Americano - Evolução da Obra de Fernando Flávio Marques de Almeida. Beca, São Paulo, pp. 265-279.

Milani, E.J., De Wit, M.J., 2008. Correlations between the classic Paraná and Cape-Karoo sequences of South America and southern Africa and their basin infills flanking the Gondwanides: du Toit revisited. In: Geological Society London, Special Publications, vol. 294 (1), pp. 319-342.

Milani, E.J., França, A.B., Schneider, R.L., 1994. Bacia do Paraná. Bol. Geociênc. Petrobras 8 (1), 69-82.

Milani, E.J., Melo, J.H.G., Souza, P.A., Fernandes, L.A., França, A.B., 2007a. Bacia do Paraná. Bol. Geociênc. Petrobras 15 (2), 265-287.

Milani, E.J., Rangel, H.D., Bueno, G.V., Stica, J.M., Winter, W.R., Caixeta, J.M., Pessoa Neto, O.C., 2007b. Bacias Sedimentares Brasileiras - Cartas Estratigráficas. Bol. Geociênc. Petrobras 15 (2). Anexo.

Mitrovica, J.X., Beaumont, C., Jarvis, G.T., 1989. Tilting of continental interiors by the dynamical effects of subduction. Tectonics 8 (5), 1079-1094. http://dx.doi.org/ 10.1029/TC008i005p01079.

Molina, E.C., Ussami, N., Sá, N.C., Blitzkow, D., 1999. Interpretação dos dados gravimétricos da parte norte da bacia do Paraná. Rev. Bras. Geociênc. 19, 187-196.

Montefeltro, F.C., Laurini, C.R., Langer, M.C., 2009. Multicusped crocodyliform teeth from the upper Cretaceous (Sao Jose do Rio Preto formation, Bauru group) of Sao Paulo, Brazil. Cretac. Res. 30 (5), 1279-1286. http://dx.doi.org/10.1016 j.cretres.2009.07.003.

Montefeltro, F.C., Larsson, H.C.E., Langer, M.C., 2011. A new Baurusuchid (Crocodyliformes, Mesoeucrocodylia) from the late Cretaceous of Brazil and the phylogeny of Baurusuchidae. PLoS One 6 (7). http://dx.doi.org/10.1371/ journal.pone.0021916.

Moreira, J.L.P., Madeira, C.V., Gil, J.A., Machado, M.A.P., 2007. Bacia de Santos. Bol. Geociênc. Petrobras 15 (2), 531-549.

Moretti, I., Baby, P., Mendez, E., Zubieta, D., 1996. Hydrocarbon generation in relation to thrusting in the Sub Andean Zone from 18 to 22oS, Bolivia. Pet. Geosci. 2 $17-28$

Mpodozis, C., Arriagada, C., Basso, M., Roperch, P., Cobbold, P., Reich, M., 2005. Late Mesozoic to Paleogene stratigraphy of the Salar de Atacama Basin, Antofagasta, Northern Chile: implications for the tectonic evolution of the Central Andes. Tectonophysics 399, 125-154.

Musacchio, E.A., 1973. Charophytas y ostrácodos no marinos del Grupo Neuquén (Cretácico Superior) en algunos afloramientos de las provincias de Río Negro y Neuquén en la República Argentina. Rev. Mus. La Plata 48, 1-33.

Musacchio, E.A., 2000. Biostratigraphy and biogeography of Cretaceous charophytes from South America. Cretac. Res. 21 (2-3), 211-220.

Musacchio, E.A., 2006. Charophyta del Cretácico tardío y el Paleoceno del centro oeste de Argentina. Rev. Bras. Paleontol. 9, 93-100.

Musacchio, E.A., 2010. Upper Cretaceous Lychnothamnus, Nitella and Tolypella (Charophyta) from Zampal, Argentina. Cretac. Res. 31 (5), 461-472. http://dx doi.org/10.1016/j.cretres.2010.05.010.

Musacchio, E.A., Simeoni, M., 1991. Taxonomy of some Cretaceous non-marine ostracods of palaeobiogeographical interest. Neues Jahrb. für Geol. Palaöntol. 180, $349-389$.

Musacchio, E.A., Vallati, P., 2007. Late Cretaceous non marine microfossils of the Plottier formation at Zampal, Argentina. Cuad. del Mus. Geomin. 8, 273-278.

Nava, W.R., Martinelli, A.G., 2011. A new squamate lizard from the upper Cretaceous Adamantina formation (Bauru group), Sao Paulo State, Brazil. An. Acad. Bras. Ciencias 83 (1), 291-299.

Noblet, C., Lavenu, A., Marocco, R., 1996. Concept of continuum as opposed to periodic tectonism in the Andes. Tectonophysics 255 (1-2), 65-78. http://dx.doi. org/10.1016/0040-1951(95)00081-X.

Nobre, P.H., Carvalho, I.S., Vasconcellos, F.M., Nava, W.R., 2007. Mariliasuchus robustus, um Novo Crocodylomorpha (Mesoeucrocodylia) da Bacia Bauru, Brasil. Anuário do Inst. Geociênc. 30 (1), 38-49.

Novas, F.E., Carvalho, I.S., Ribeiro, L.C.B., Mendez, A.H., 2008. First abelisaurid bone remains from the Maastrichtian Marilia formation, Bauru Basin, Brazil. Cretac. Res. 29 (4), 625-635. http://dx.doi.org/10.1016/j.cretres.2008.01.010.

Novas, F.E., Pais, D.F., Pol, D., Carvalho, I.S., Scanferla, A., Mones, A., Riglos, M.S 2009. Bizarre notosuchian crocodyliform with associated eggs from the upper Cretaceous of Bolivia. J. Vertebr. Paleontol. 29 (4), 1316-1320. http://dx.doi.org 10.1671/039.029.0409.

Novas, F.E., Agnolín, F.L., Ezcurra, M.D., Porfiri, J., Canale, J.I., 2013. Evolution of the carnivorous dinosaurs during the Cretaceous: the evidence from Patagonia. Cretac. Res. 45 (0), 174-215. http://dx.doi.org/10.1016/j.cretres.2013.04.001.

Nurnberg, D., Müller, R.D., 1991. The tectonic evolution of the South-Atlantic from late Jurassic to present. Tectonophysics 191 (1-2), 27-53. http://dx.doi.org/ 10.1016/0040-1951(91)90231-G.
Parras, A., Griffin, M., 2013. Late Cretaceous (Campanian/Maastrichtian) freshwater to restricted marine mollusc fauna from the Loncoche formation, Neuquén Basin, west-central Argentina. Cretac. Res. 40 (0), 190-206. http://dx.doi.org/10. 1016/j.cretres.2012.07.002.

Paula e Silva, F., Bianchi Neto, C., Ricaldi, A.E.M., Sapio, A.J., 1994. Estudo estratigráfico do Grupo Bauru na região de Presidente Prudente com base em perfis geofísicosde poços para água. Geociências 13 (1), 63-82.

Paula e Silva, F., Chang, H.K., Caetano-Chang, M.R., 2005. Estratigrafia de subsuperfície do Grupo Bauru (K) no Estado de São Paulo. Rev. Bras. Geociênc. 35 (1), 77-88.

Paula e Silva, F., Chang, H.K., Caetano-Chang, M.R., Stradioto, M.R., 2006. Sucessão sedimentar do Grupo Bauru na região de Pirapozinho (SP). Geociências 25 (1), $17-26$.

Paula e Silva, F., Kiang, C.H., Caetano-Chang, M.R., 2009. Sedimentation of the Cretaceous Bauru group in Sao Paulo, Parana Basin, Brazil. Journal of South American Earth Sciences 28 (1), 25-39. http://dx.doi.org/10.1016/ j.jsames.2009.02.008.

Pereira, M.J., Feijó, F.J., 1994. Bacia de Santos. Bol. Geociênc. Petrobras 8 (1), 219-234.

Pérez-Gussinyé, M., Lowry, A.R., Watts, A.B., 2007. Effective elastic thickness of South America and its implications for intracontinental deformation. Geochem. Geophys. Geosyst. 8 (5), 1-22. http://dx.doi.org/10.1029/2006GC001511.

Perrotta, M.M., Salvador, E.D., Lopes, R.C., D'Agostino, L.Z., Peruffo, N., Gomes, S.D., Sachs, L.L.B., Meira, V.T., Garcia, M.G.M., Lacerda Filho, J.V., 2005. Mapa Geológico do Estado de São Paulo. In: Programa Geologia do Brasil. Serviço Geológico do Brasil - CPRM, São Paulo.

Petri, S., 1955. Charophyta cretácicas de São Paulo (Formacão Bauru). Bol. Soc. Bras. Geol. 4, 67-72.

Pfiffner, O., Gonzalez, L., 2013. Mesozoic-Cenozoic evolution of the western margin of South America: case study of the Peruvian Andes. Geosciences 3 (2), 262.

Pindell, J.L., Tabbutt, K.D., 1995. Mesozoic-Cenozoic Andean paleogeography and regional controls on hydrocarbon systems. In: Tankard, A.J., Suarez Soruco, R., Welsink, H.J. (Eds.), Petroleum Basins of South America. American Association of Petroleum Geologists, pp. 101-128.

Plint, A.G., Hart, B.S., Donaldson, W.S., 1993. Lithospheric flexure as a control on stratal geometry and facies distribution in upper Cretaceous rocks of the Alberta foreland basin. Basin Res. 5, 69-77.

Pol, D., Nascimento, P.M., Carvalho, A.B., Riccomini, C., Pires-Domingues, R.A., Zaher, H., 2014. A new notosuchian from the late Cretaceous of Brazil and the phylogeny of advanced Notosuchians. PLoS One 9 (4). http://dx.doi.org/10.1371/ journal.pone.0093105.

Prezzi, C.B., Uba, C.E., Götze, H.-J., 2009. Flexural isostasy in the Bolivian Andes: chaco foreland basin development. Tectonophysics 474 (3-4), 526-543. http:/ dx.doi.org/10.1016/j.tecto.2009.04.037.

Ramos, V.A., 1999. Plate tectonic setting of the Andean Cordillera. Episodes 22 (3), $183-190$.

Ramos, V.A., 2009. Anatomy and global context of the Andes: main geologic features and the Andean orogenic cycle. In: Kay, S.M., Ramos, V.A., Dickinson, W.R. (Eds.), Backbone of the Americas: Shallow Subduction, Plateau Uplift, and Ridge and Terrane Collision. Geological Society of America, pp. 31-65.

Ramos, V.A., 2010. The tectonic regime along the Andes: present-day and Mesozoic regimes. Geol. J. 45, 2-45. http://dx.doi.org/10.1002/gj.1193.

Ramos, V.A., Alemán, A., 2000. Tectonic evolution of the Andes. In: Cordani, U.G., Milani, E.J., Thomaz Filho, A., Campos, D.A. (Eds.), Tectonic Evolution of South America. 31st International Geological Congress, Rio de Janeiro, pp. 635-685.

Ramos, V.A., Vujovich, G., Martino, R., Otamendi, J., 2010. Pampia: a large cratonic block missing in the Rodinia supercontinent. J. Geodyn. 50 (3-4), 243-255. http://dx.doi.org/10.1016/j.jog.2010.01.019.

Rangel, H.D., Martins, F.A.L., Esteves, F.R., Feijó, F.J., 1994. Bacia de Campos. Bol. Geociênc. Petrobras 8 (1), 203-217.

Reyes, F.C., 1972. Correlaciones en el Cretacico de la Cuenca Andina de Bolivia, Peru y Chile. Rev. Técnica YPFB 1 (2), 101-144.

Riccomini, C., 1997a. Considerações sobre a posição estratigráfica e tectonismo deformador da Formação Itaqueri na porção centro-leste do Estado de São Paulo. Rev. do Inst. Geociênc. 18 (1/2), 41-48.

Riccomini, C., 1997b. Arcabouço estrutural e aspectos do tectonismo gerador e deformador da Bacia Bauru no Estado de São Paulo. Rev. Bras. Geociênc. 27 (2), 153-162.

Riccomini, C. Velázquez V.F. Gomes, C.B., 2005. Tectonic controls of the Mesozoic and Cenozoic alkaline magmatism in central-southeastern Brazilian platform. In: Comin-Chiaramonti, P., Gomes, C.B. (Eds.), Mesozoic to Cenozoic Alkaline Magmatism in the Brazilian Platform. Edusp, São Paulo, pp. 31-56.

Rocha-Júnior, E.R.V., Puchtel, I.S., Marques, L.S., Walker, R.J., Machado, F.B., Nardy, A.J.R., Babinski, M., Figueiredo, A.M.G., 2012. Re-Os isotope and highly siderophile element systematics of the Paraná continental flood basalts (Brazil). Earth Planet. Sci. Lett. 337-338, 164-173. http://dx.doi.org/10.1016/j.epsl.2012. 04.050.

Rocha-Júnior, E.R.V., Marques, L.S., Babinski, M., Nardy, A.J.R., Figueiredo, A.M.G., Machado, F.B., 2013. $\mathrm{Sr}-\mathrm{Nd}-\mathrm{Pb}$ isotopic constraints on the nature of the mantle sources involved in the genesis of the high-Ti tholeiites from northern Paraná Continental Flood Basalts (Brazil). J. S. Am. Earth Sci. 46, 9-25. http://dx.doi.org/ 10.1016/j.jsames.2013.04.004.

Romano, P.S.R., Oliveira, G.R., Azevedo, S.A.K., Kellner, A.W.A., Campos, D.A., 2013 New information about Pelomedusoides (Testudines: Pleurodira) from the Cretaceous of Brazil morphology and evolution of turtles. Morphol. Evol. Turtles 
261-275. http://dx.doi.org/10.1007/978-94-007-4309-0_16

Rouchy, J.M., Camoin, G., Casamova, J., Deconinck, J.F., 1993. The central PalaeoAndean Basin of Bolivia (Potosi Area) during the late Cretaceous and Early Tertiary - reconstruction of ancient saline lakes using sedimentological, paleoecological and stable-isotope records. Palaeogeogr. Palaeoclimatol. Palaeoecol. 105 (3-4), 179-198. http://dx.doi.org/10.1016/0031-0182(93)90083-U.

Ruberti, E., Gomes, C.B., Comin-Chiaramonti, P., 2005. The alkaline magmatism from Ponta Grossa Arch. In: Comin-Chiaramonti, P., Gomes, C.B. (Eds.), Mesozoic to Cenozoic Alkaline Magmatism in the Brazilian Platform. Edusp/Fapesp, São Paulo, pp. 473-522.

Salfity, J.A., Marquillas, R.A., 1994. Tectonic and sedimentary evolution of the Cretaceous-Eocene Salta group basin, Argentina. In: Salfity, J.A. (Ed.), Cretaceous Tectonics of the Andes. Friedr. Vieweg \& Sohn, Braunschweig/Weisbaden, pp. $266-315$.

Sallun Filho, W., Martins Sallun, A.E., Teixeira, A.L., Negri, F.A., Azevedo Sobrinho, J.M., 2009. Geologia de subsuperfície do Estado de São Paulo - 75 anos de levantamentos do Instituto Geológico (1932-2007). Secretaria do Meio Ambiente, Instituto Geológico, São Paulo.

Santucci, R.M., Arruda-Campos, A.C., 2011. A new sauropod (Macronaria, Titanosauria) from the Adamantina formation, Bauru group, upper Cretaceous of Brazil and the phylogenetic relationships of Aeolosaurini. Zootaxa 3085, 1-33.

Santucci, R.M., Bertini, R.J., 2001. Distribuição paleogeográfica e biocronológica dos titanossauros (Saurischia, Sauropoda) do Grupo Bauru, Cretáceo Superior do sudeste brasileiro. Rev. Bras. Geociênc. 31 (3), 307-314.

Scotese, C.R., 2001. Atlas of Earth History. Vol. 1, Paleogeography. PALEOMAP Project, Arlington, Texas.

Sempere, T., 1995. Phanerozoic evolution of Bolivia and adjacent regions. In: Tankard, A.J., Suárez Soruco, R., Welsink, H.J. (Eds.), Petroleum Basins of South America. American Association of Petroleum Geologists, pp. 207-230.

Sempere, T., Butler, R.F., Richards, D.R., Marshall, L.G., Sharp, W., Swisher, C.C., 1997. Stratigraphy and chronology of upper Cretaceous lower Paleogene strata in Bolivia and northwest Argentina. Geol. Soc. Am. Bull. 109 (6), 709-727 doi: 10.1130/0016-7606(1997)109<0709:SACOUC > 2.3.CO;2.

Siks, B.C., Horton, B.K., 2011. Growth and fragmentation of the Andean foreland basin during eastward advance of fold-thrust deformation, Puna plateau and Eastern Cordillera, northern Argentina. Tectonics 30 (6), TC6017. http:/| dx.doi.org/10.1029/2011TC002944.

Silva, A.J.P., Lopes, R.C., Vasconcelos, A.M., Bahia, R.B.C., 2003. Bacias Sedimentares Paleozóicas e Meso-Cenozóicas Interiores. In: Bizzi, L., Schobbenhaus, A.C., Vidotti, R.M., Gonçalves, J.H. (Eds.), Geologia, Tectônica e Recursos Minerais do Brasil. Serviço Geológico do Brasil - CPRM, Brasília.

Soares, P.C., Landim, P.M.B., Fúlfaro, V.J., Sobreiro Neto, A.F., 1980. Ensaio de caracterização estratigráfica do Cretáceo no Estado de São Paulo: Grupo Bauru. Rev. Bras. Geociênc. 10 (3), 177-185.

Soares, A.P., Soares, P.C., Holz, M., 2008. Correlações Estratigráficas Conflitantes no Limite Permo-Triássico no Sul da Bacia do Paraná: O Contato Entre Duas Seqüências e Implicações na Configuração Espacial do Aqüífero Guarani. Rev. Pesqui. em Geociênc. 35 (2), 115-133.

Spagnuolo, M.G., Folguera, A., Litvak, V., Vera, E.A.R., Ramos, V.A., 2012. Late Cretaceous arc rocks in the Andean retroarc region at 36.5 degrees S: evidence supporting a Late Cretaceous slab shallowing. J. S. Am. Earth Sci. 38, 44-56. http://dx.doi.org/10.1016/j.jsames.2012.05.002.

Stica, J.M., Zalan, P.V., Ferrari, A.L., 2014. The evolution of rifting on the volcanic margin of the Pelotas Basin and the contextualization of the Parana-Etendeka LIP in the separation of Gondwana in the South Atlantic. Mar. Pet. Geol. 50, 1-21. http://dx.doi.org/10.1016/j.marpetgeo.2013.10.015.

Suguio, K., 1981. Fatores paleoambientais e paleoclimáticos e subdivisão estratigráfica do Grupo Bauru. In: Mesa redonda: a Formação Bauru no Estado de São Paulo e Regiões Adjacentes, São Paulo.

Suguio, K., Fúlfaro, V.J., Amaral, G., Guidorzi, L.A., 1977. Comportamentos estratigráfico e estrutural da Formação Bauru nas regiões administrativas 7 (Bauru), 8 (São José do Rio Preto) e 9 (Araçatuba) no Estado de São Paulo. In: 1 Simpósio de Geologia Regional, São Paulo.

Thiede, D.S., Vasconcelos, P.M., 2010. Parana flood basalts: rapid extrusion hypothesis confirmed by new Ar-40/Ar-39 results. Geology 38 (8), 747-750. http://dx.doi.org/10.1130/G30919.1.

Thybo, H., Artemieva, I.M., 2013. Moho and magmatic underplating in continental lithosphere. Tectonophysics 609, 605-619.

Tunik, M., Folguera, A., Naipauer, M., Pimentel, M., Ramos, V.A., 2010. Early uplift and orogenic deformation in the Neuquén Basin: Constraints on the Andean uplift from U-Pb and $\mathrm{Hf}$ isotopic data of detrital zircons. Tectonophysics 489, $258-273$.

Turner, A.H., Sertich, J.J.W., 2010. Phylogenetic history of Simosuchus clarki (Crocodyliformes: Notosuchia) from the Late Cretaceous of Madagascar. J. Vertebr. Paleontol. 30 (sp1), 177-236. http://dx.doi.org/10.1080/02724634.2010.532348.

Uba, C.E., Heubeck, C., Hulka, C., 2006. Evolution of the late Cenozoic Chaco foreland basin, Southern Bolivia. Basin Res. 18 (2), 145-170. http://dx.doi.org/10.1111/ j.1365-2117.2006.00291.x.

Uliana, M.A., Musacchio, E.A., 1978. Microfósiles calcáreos no marinos del Cretácico Superior en el Zampal, Provincia de Mendoza, Argentina. Ameghiniana 15, $111-135$.

Valarelli, J.V., Coutinho, J.M.V., Madureira Filho, J.B.M., Gomes, C.B., 1985. O Tinguaíto de Jaboticabal, SP. Bol. do Inst. Geociênc. 16, 1-10.

Vallati, P., 2010. Asociaciones palinológicas con angiospermas en el Cretácico Superior de la Cuenca Neuquina, Argentina. Rev. Bras. Paleontol. 13 (2), 143-158. http://dx.doi.org/10.4072/rbp.2010.2.07

Van Decar, J.C., James, D., Assumpção, M., 1995. Seismic evidence for a fossil mantle plume beneath South America and implications for driving forces. Nature 378, 25-31.

van der Meijde, M., Julià, J., Assumpção, M., 2013. Gravity derived Moho for South America. Tectonophysics 609, 456-467. http://dx.doi.org/10.1016/j.tecto.2013. 03.023.

Varela, A.N., Poiré, D.G., Martin, T., Gerdes, A., Goin, F.J., Gelfo, J.N., Hoffmann, S. 2012. U-Pb zircon constraints on the age of the Cretaceous Mata Amarilla formation, Southern Patagonia, Argentina: its relationship with the evolution of the Austral Basin. Andean Geol. 39 (3), 359-379.

Viramonte, J.G., Kay, S.M., Becchio, R., Escayola, M., Novitski, I., 1999. Cretaceous rift related magmatism in central-western South America. J. S. Am. Earth Sci. 12 (2), 109-121. http://dx.doi.org/10.1016/S0895-9811(99)00009-7.

Wanderley Filho, J.R., Eiras, J.F., Vaz, P.T., 2007. Bacia do Solimões. Bol. Geociênc. Petrobras 15 (2), 217-225.

Wang, X.L., Zhou, Z.H., 2003. A new pterosaur (Pterodactyloidea, Tapejaridae) from the early Cretaceous Jiufotang formation of western Liaoning, China and its implications for biostratigraphy. Chin. Sci. Bull. 48 (1), 16-23. http://dx.doi.org/ $10.1360 / 03$ tb9003.

Watts, A.B., 1992. The effective elastic thickness of the lithosphere and the evolution of foreland basins. Basin Res. 4 (3-4), 169-178. http://dx.doi.org/10.1111/j.1365117.1992.tb00043.x.

Welsink, H.J., Martinez, E., Aranibar, O., Jarandilla, J., 1995. Structural inversion of a Cretaceous rift basin, southern Altiplano, Bolivia. In: Suarez Soruco, A.J. Tankard, R., Welsink, H.J. (Eds.), Petroleum Basins of South America. American Association of Petroleum Geologists, pp. 305-324.

White, R.S., McKenzie, D., 1995. Mantle plumes and flood basalts. J. Geophys. Res. Solid Earth 100 (B9), 17543-17585. http://dx.doi.org/10.1029/95JB01585.

Wiese, F., Schulze, F., 2005. The upper Cenomanian (Cretaceous) ammonite Neolobites vibrayeanus (d'Orbigny, 1841) in the Middle East: taxonomic and palaeoecologic remarks. Cretac. Res. 26 (6), 930-946. http://dx.doi.org/10.1016/ j.cretres.2005.06.005.

Winter, W.R., Jahnert, R.J., França, A.B., 2007. Bacia de Campos. Bol. Geociênc. Petrobras 15 (2), 511-529.

Zaher, H., Pol, D., Carvalho, A.B., Riccomini, C., Campos, D., Nava, W.R., 2006. Redescription of the cranial morphology ofMariliasuchus Amarali, and its phylogenetic affinities (Crocodyliformes, Notosuchia). Am. Mus. Novitates 1-40 doi: 10.1206/0003-0082(2006)3512[1:ROTCMO]2.0.CO;2.

Zalán, P.V., Oliveira, J.A.B., 2005. Origem e evolução estrutural do Sistema de Riftes Cenozóicos do Sudeste do Brasil. Bol. Geociênc. Petrobras 13 (2), 269-300.

Zalán, P.V., Wolff, S., Astolfi, M.A.M., Vieira, I.S., Conceição, J.C.J., Appi, V.T., Santos Neto, E.V., Cerqueira, J.R., Marques, A., 1990. The Parana Basin. In Leighton, M.W., Kolata, D.R., Oltz, D.T., James Eidel, J.J. (Eds.), Interior Cratonic Basins. American Association of Petroleum Geologists, Tulsa, pp. 681-708.

Zamora Valcarce, G., Zapata, T., del Pino, D., Ansa, A., 2006. Structural evolution and magmatic characteristics of the Agrio fold-and-thrust belt. Geological Society of America Special Papers. In: Kay, S.M., Ramos, V.A. (Eds.), Evolution of an Andean Margin: a Tectonic and Magmatic View from the Andes to the Neuquén Basin ( $35^{\circ}-39^{\circ}$ S Lat). Geological Society of America, pp. 125-145.

Zerfass, H., Chemale Jr., F., Schultz, C.L., Lavina, E., 2004. Tectonics and sedimentation in Southern South America during Triassic. Sediment. Geol. 166 (3-4) 265-292. http://dx.doi.org/10.1016/j.sedgeo.2003.12.008.

Zerfass, H., Chemale Jr., F., Lavina, E., 2005. Tectonic control of the Triassic Santa Maria Supersequence of the Paraná Basin, Southernmost Brazil, and its Correlation to the Waterberg Basin, Namibia. Gondwana Res. 8 (2), 163-176. http:// dx.doi.org/10.1016/S1342-937X(05)71115-1.

\section{Further reading}

Alaug, A.S., Batten, D.J., Ahmed, A.F., 2013. Organic geochemistry, palynofacies and petroleum potential of the Mukalla Formation (late Cretaceous), block 16, eastern Yemen. Mar. Pet. Geol. 46, 67-91. http://dx.doi.org/10.1016/j. marpetgeo.2013.05.018

Almeida, E.B., Avilla, L.S., Candeiro, C.R.A., 2004. Restos caudais de Titanosauridae da Formação Adamantina (Turoniano-Santoniano), sítio do Prata, Estado de Minas Gerais, Brasil. Rev. Bras. Paleontol. 7 (2), 239-244.

Alvarenga, H., Nava, W.R., 2005. Aves Enantiornithes do Cretáceo Superior da Formação Adamantina do Estado de Sao Paulo, Brasil. In: II Congresso Latinoamericano de Paleontologia de Vertebrados, Rio de Janeiro.

Araújo Júnior, H.I., Marinho, T.D., 2013. Taphonomy of a Baurusuchus (Crocodyliformes, Baurusuchidae) from the Adamantina formation (upper Cretaceous, Bauru Basin), Brazil: implications for preservational modes, time resolution and paleoecology. J. S. Am. Earth Sci. 47, 90-99. http://dx.doi.org 10.1016/j.jsames.2013.07.006.

Archangelsky, S., 1994. Comparative ultrastructure of three early Cretaceous gymnosperm pollen grains: Araucariacites, Balmeiopsisand Callialasporites. Rev. Palaeobot. Palynol. 83, 185-198.

Arid, F.M., Vizotto, L.D., 1966. Ciência Cult. 18, 422-428.

Arratia, G., López-Arbarello, A., Prasad, G.V.R., Parmar, V., Kriwet, J., 2004. Late Cretaceous-Paleocene percomorphs (Teleostei) from India - early radiation of perciformes. In: Arratia, G., Wilson, M.V.H., Cloutier, R. (Eds.), Recent Advances in the Origin and Early Radiation of Vertebrates. Verlag Dr. Friedrich Pfeil München, Germany, pp. 635-663. 
Azevedo, R.P., Vasconcellos, P.L., Candeiro, C.R., Bergqvist, L.P., 2007. Restos microscópicos de vertebrados fósseis do Grupo Bauru (Neocretáceo), no oeste do Estado de São Paulo, Brasil. In: Carvalho, I.S., Cassab, R.C., Schwanke, C., Carvalho, M.A., Fernandes, A.C., Rodrigues, M.A.C., Carvalho, M.S., Arai, M. Oliveira, M.E.Q. (Eds.), Paleontologia: Cenários da Vida. Interciências, Rio de Janeiro, 541-549.

Azevedo, R.P.F., Simbras, F.M., Furtado, M.R., Candeiro, C.R.A., Bergqvist, L.P., 2013. First Brazilian carcharodontosaurid and other new theropod dinosaur fossils from the Campanian-Maastrichtian Presidente Prudente formation, Sao Paulo State, southeastern Brazil. Cretac. Res. 40, 131-142. http://dx.doi.org/10.1016 j.cretres.2012.06.004

Báez, A.M., Petri, S., 1989. Baurubatrachus pricei, nov. gen. et sp., un Anuro del Cretácico Superior de Minas Gerais, Brasil. An. Acad. Bras, Ciências 61, 447-458.

Beaumont, C., Quinlan, G., Hamilton, J., 1988. Orogeny and stratigraphy: numerical models of the paleozoic in the eastern interior of North America. Tectonics 7 (3) 389-416. http://dx.doi.org/10.1029/TC007i003p00389.

Bertini R.J., Evidências de Abelisauridae (Carnosauria: Saurischia) do Neocretáceo da Bacia do Paraná, In: 4 Simpósio sobre o Cretáceo do Brasil, Águas de São Pedro, 1996.

Bertini, R.J., Franco-Rosas, A.C., 2001. Scanning electronic microscopic analysis on maniraptoriformes teeth from the upper Cretaceous of Southeastern Brazil. J. Vertebr. Paleontol. 21 (3). Abstracts of Papers Sixty-First Annual Meeting Society of Vertebrate Paleontology, Museum of the Rockies, Montana State, University Boseman, Montana:33A.

Beu, A.G., Marshall, B.A., Reay, M.B., 2014. Mid-Cretaceous (Albian-Cenomanian) freshwater Mollusca from the Clarence Valley, Marlborough, New Zealand, and their biogeographical significance. Cretac. Res. 49 (0), 134-151. http://dx.doi. org/10.1016/j.cretres.2014.02.011.

Calvo, J.O., Porfiri, J.D., Veralli, C., Novas, F.E., Poblete, F., 2004. Phylogenetic status of Megaraptor namunhuaiquii Novas based on a new specimen from Neuquén, Patagonia, Argentina. Ameghiniana 41, 565-575.

Campos, D.A., Suarez, J.M., Riff, D., Kellner, A.W.A., 2001. Short note on a new Baurusuchidae (Crocodyliformes, Metasuchia) from the upper Cretaceous of Brazil. Bol. do Mus. Nac. 57, 1-7.

Campos, D.A., Kellner, A.W.A., Bertini, R.J., Santucci, R.M., 2005. On a titanosaurid (Dinosauria, Sauropoda) vertebral column from the Bauru group, late Cretaceous of Brazil. Arq. do Mus. Nac. 63, 565-593.

Campos, D.A., Oliveira, G.R., Figueiredo, R.G., Riff, D., Azevedo, S.A.K., Carvalho, L.B. Kellner, A.W.A., 2011. On a new peirosaurid crocodyliform from the Uppe Cretaceous, Bauru group, southeastern Brazil. An. Acad. Bras. Ciências 83 (1), 317-327.

Candeiro, C.R.A., Abranches, C.T., Abrantes, E.A., Avilla, L.S., Martins, V.C., Moreira, A.L., Torres, S.R., Bergqvist, L.P., 2004. Dinosaurs remains from western Sao Paulo state, Brazil (Bauru Basin, Adamantina formation, upper Cretaceous). J. S. Am. Earth Sci. 18 (1), 1-10. http://dx.doi.org/10.1016/j.jsames.2004.08.004.

Candeiro, C.R.A., Agnolin, F., Martinelli, A.G., Buckup, P.A., 2012a. First bird remains from the upper Cretaceous of the Peiropolis site, Minas Gerais state, Brazil. Geodiversitas 34 (3), 617-624. http://dx.doi.org/10.5252/g2012n3a8.

Candeiro, C.R.A., Cau, A., Fanti, F., Nava, W.R., Novas, F.E., 2012b. First evidence of an unenlagiid (Dinosauria, Theropoda, Maniraptora) from the Bauru group, Brazil. Cretac. Res. 37, 223-226. http://dx.doi.org/10.1016/j.cretres.2012.04.001.

Carbonaro, F.A., Rohn, R., Ghilardi, R.P., 2013. Conchostráceos Palaeolimnadiopsis (Spinicaudata, Crustacea) do Grupo Bauru (Cretáceo Superior, Bacia Bauru): Taxonomia, Paleoecologia e Paleobiogeografia. Rev. Bras. Paleontol. 16 (2) 283-296. http://dx.doi.org/10.4072/rbp.2013.2.09.

Carvalho, I.D., Ribeiro, L.C.B., Avilla, L.D., 2004. Uberabasuchus terrificus sp nov., a new Crocodylomorpha from the Bauru Basin (upper Cretaceous), Brazil. Gondwana Res. 7 (4), 975-1002. http://dx.doi.org/10.1016/S1342-937X(05) 71079-0.

Carvalho, I.S., Campos, A.C.A., Nobre, P.H., 2005. Baurusuchus salgadoensis, a new crocodylomorpha from the Bauru Basin (Cretaceous), Brazil. Gondwana Res. 8 (1), 11-30. http://dx.doi.org/10.1016/S1342-937X(05)70259-8.

Carvalho, I.D., Vasconcellos, F.M., Tavares, S.A.S., 2007. Montealtosuchus arrudacamposi, a new peirosaurid crocodile (Mesoeucrocodylia) from the late Cretaceous Adamantina formation of Brazil. Zootaxa 1607, 35-46.

Carvalho, I.S., Teixeira, V.D.A., Ferraz, M.L.D., Ribeiro, L.C.B., Martinelli, A.G., Neto, F.M., Sertich, J.J.W., Cunha, G.C., Cunha, I.C., Ferraz, P.F., 2011. Campinasuchus dinizi gen. et sp nov., a new late Cretaceous baurusuchid (Crocodyliformes) from the Bauru Basin, Brazil. Zootaxa 2871, 19-42.

Cione, A.L., Prasad, G.V.R., 2002. The oldest known Catfish (Teleostei: Siluriformes) from Asia (India, Late Cretaceous). J. Paleontol. 76 (1), 190-193.

de la Fuente, M.S., 2003. Two new pleurodiran turtle from the Portezuelo formation (upper Cretaceous) of the Northern Patagonia, Argentina. J. Paleontol. 77 (3) 559-575.

DeCelles, P.G., Giles, K.A., 1996. Foreland basin systems. Basin Res. 8 (2), 105-123. http://dx.doi.org/10.1046/j.1365-2117.1996.01491.x.

DeCelles, P.G., Zandt, G., Beck, S.L., Currie, C.A., Ducea, M.N., Kapp, P., Gehrels, G.E., Carrapa, B., Quade, J., Schoenbohm, L.M., 2015. Cyclical orogenic processes in the Cenozoic central Andes. In: DeCelles, P.G., Ducea, M.N., Carrapa, B. Kapp, P.A. (Eds.), Geodynamics of a Cordilleran Orogenic System: the Centra Andes of Argentina and Northern Chile. Geological Society of America, Bolder, pp. 459-491.

Delcourt, R., Grillo, O.N., 2014. On Maniraptoran material (Dinosauria: Theropoda) from Vale do Rio do Peixe formation, Bauru group, Brazil. Rev. Bras. Paleontol. 17 (3), 307-316. http://dx.doi.org/10.4072/rbp.2014.3.03.
El Beialy, S.Y., El Atfy, H.S., Zavada, M.S., El Khoriby, E.M., Abu-Zied, R.H., 2010. Palynological, palynofacies, paleoenvironmental and organic geochemical studies on the upper Cretaceous succession of the GPTSW-7 well, North Western Desert, Egypt. Mar. Pet. Geol. 27 (2), 370-385. http://dx.doi.org/10. 1016/j.marpetgeo.2009.10.006.

Fernandes, L.A., Basilici, G., 2009. Transition of ephemeral palustrine to aeolian deposits in a continental arid - semi-arid environment (Upper Cretaceous Bauru Basin, Brazil). Cretac. Res. 30 (3), 605-614. http://dx.doi.org/10.1016/ j.cretres.2008.12.002.

Franco-Rosas, A.C., 2002. Methodological parameters for identification and taxonomic classification of isolated theropodomorph teeth. An. Acad. Bras. Ciências 74, 367.

França, M.A.G., Langer, M.C., 2005. A new freshwater turtle (Reptilia, Pleurodira, Podocnemidae) from the upper Cretaceous (Maastrichtian) of Minas Gerais, Brazil. Geodiversitas 27 (3), 391-411.

Gayet, M., Brito, P.M., 1989. New Ichthyofauna from the upper Cretaceous of the Bauru group (São Paulo and Minas Gerais, Brazil). Geobios 22 (6), 841-847. http://dx.doi.org/10.1016/S0016-6995(89)80075-0.

Geroto, C.F.C., Bertini, R.J., 2012. Descrição de um espécime juvenil de Baurusuchidae (Crocodyliformes: Mesoeucrocodylia) do Grupo Bauru (Neocretáceo): considerações preliminares sobre ontogenia. Rev. do Inst. Geol. 33 (2), 13-29. http://dx.doi.org/10.5935/0100-929X.20120007.

Ghilardi, R.P., Rodrigues, S.C., Simone, L.R.L., Carbonaro, F.A., Nava, W.R., 2011. Moluscos fósseis do Grupo Bauru. In: Carvalho, I.S., Srivastava, N.K., Strochschoen Júnior, O., Lana, C.C. (Eds.), Paleontologia: Cenários da Vida. Interciência, Rio de Janeiro, pp. 197-208.

Hole, M.J., Saunders, A.D., Roger, G., Sykes, M.A., 1995. The relationship between alkaline magmatism, lithospheric extension and slab window formation along continental destructive plate margins. In: Smellie, J.L. (Ed.), Volcanism Associated with Extension at Consuming Plate Margins. Geological Society, London, pp. 265-285.

Hole, M.J., Rogers, G., Saunders, A.D., Storey, M., 2001. Relation between alkalic volcanism and slab-window formation. Geology 19, 657-660.

Iori, F.V., Carvalho, I.S., 2009. Morrinhosuchus luziae, um novo Crocodylomorpha Notosuchia da Bacia Bauru, Brasil. Rev. Bras. Geociênc. 39 (4), 717-725.

Iori, F.V., Garcia, K.L., 2012. Barreirosuchus franciscoi, um novo Crocodylomorpha Trematochampsidae da Bacia Bauru, Brasil. Rev. Bras. Geociênc. 42 (2), 397-410. http://dx.doi.org/10.5327/Z0375-75362012000200013.

Kellner, A.W.A., Azevedo, S.A.K., 1999. A new sauropod dinosaur (Titanosauria) from the late Cretaceous of Brazil. Nat. Sci. Mus. Monogr. 15, 111-142.

Kellner, A.W.A., Campos, D.A., 2000. Brief review of dinosaur studies and perspectives in Brazil. An. Acad. Bras. Ciências 72, 509-538.

Kellner, A.W.A., Campos, D.A., Trotta, M.N.F., 2005. Description of a titanosaurid caudal series from the Bauru group, late Cretaceous of Brazil. Arq. do Mus. Nac. 63, 529-564.

Kellner, A.W.A., Campos, D.A., Azevedo, S.A.K., Trotta, M.N.F., Henriques, D.D.R., Craik, M.M.T., Silva, H.P., 2006. On a new Titanosaur Sauropod from the Bauru group, Late Cretaceous of Brazil. Bol. do Mus. Nac. 74, 1-31.

Kellner, A.W.A., Campos, D.A., Riff, D., Andrade, M.B., 2011a. A new crocodylomorph (Sphagesauridae, Notosuchia) with horn-like tubercles from Brazil. Zool. J. Linn. Soc. 163, S57-S65. http://dx.doi.org/10.1111/j.1096-3642.2011.00712.x.

Kellner, A.W.A., Figueiredo, R.G., Azevedo, S.A.K., Campos, D.A., 2011b. A new cretaceous notosuchian (Mesoeucrocodylia) with bizarre dentition from Brazil. Zool. J. Linn. Soc. 163, S109-S115. http://dx.doi.org/10.1111/j.10963642.2011.00711.x.

Khand, Y., Badamgarav, D., Ariunchimeg, Y., Barsbold, R., 2000. Cretaceous system in Mongolia and its depositional environments. In: Okada, H., Mateer, N.J. (Eds.), Developments in Palaeontology and Stratigraphy. Elsevier, pp. 49-79.

Kischlat, E.E., 1994. Observações sobre Podocnemis elegans. Acta Geol. Leopoldensia 17, 345-351.

Lio, G., Agnolín, F.L., Valieri, R.J., Filippi, L., Rosales, D., 2015. A new peirosaurid (Crocodilyformes) from the late Cretaceous (Turonian-Coniacian) of Patagonia, Argentina. Hist. Biol. 1-7 http://dx.doi.org/10.1080/08912963.2015.1043999.

Louterbach, M., Roddaz, M., Bailleul, J., Antoine, P.O., Adnet, S., Kim, J.H., van Soelen, E., Parra, F., Gérard, J., Calderon, Y., Gagnaison, C., Sinninghe Damsté, J.S. Baby, P., 2014. Evidences for a Paleocene marine incursion in southern Amazonia (Madre de Dios Sub-Andean Zone, Peru). Palaeogeogr. Palaeoclimatol. Palaeoecol. 414, 451-471. http://dx.doi.org/10.1016/j.palaeo.2014.09.027.

Lu, J.C., Jin, X.S., Unwin, D.M., Zhao, L.J., Yoichi, A., Ji, O., 2006. A new species of Huaxiapterus (Pterosauria : Pterodactyloidea) from the lower cretaceous of Western Liaoning, China with comments on the systematics of tapejarid pterosaurs. Acta Geol. Sinica-English Ed. 80 (3), 315-326.

Machado, E.B., Campos, D.A., Kellner, A.W.A., 2008. On a theropod scapula (upper Cretaceous) from the Marilia formation, Bauru group, Brazil. Palaeontol. Z. 82 (3), 308-313.

Marconato, L.P. 2002. Dois novos crocodilos (Crocodyliformes, Mesoeucrocodylia) do Mato Grosso, Bacia dos Parecis: descrição e relações filogéticas com os "Notossúquios. PhD. Instituto de Geociências, Universidade Federal do Rio Grande do Sul.

Marinho, T.S., Carvalho, I.S., 2009. An armadillo-like sphagesaurid crocodyliform from the Late Cretaceous of Brazil. J. S. Am. Earth Sci. 27 (1), 36-41. http:// dx.doi.org/10.1016/j.jsames.2008.11.005.

Marinho, T.D., Iori, F.V., Carvalho, I.S., Vasconcellos, F.M., 2013. Gondwanasuchus scabrosus gen. et sp nov., a new terrestrial predatory crocodyliform (Mesoeucrocodylia: Baurusuchidae) from the Late Cretaceous Bauru Basin of Brazil. 
Cretac. Res. 44, 104-111. http://dx.doi.org/10.1016/j.cretres.2013.03.010.

Martinelli, A.G., Forasiepi, A.M., 2004. Late Cretaceous vertebrates from Bajo de Santa Rosa (Allen Formation), Río Negro province, Argentina, with the description of a new sauropod dinosaur (Titanosauridae). Rev. del Mus. Argent. Ciencias Nat. 6 (2), 257-305.

Martinelli, A.G., Sertich, J.J.W., Garrido, A.C., Praderio, Á.M., 2012. A new peirosaurid from the upper Cretaceous of Argentina: implications for specimens referred to Peirosaurus torminni Price (Crocodyliformes: Peirosauridae). Cretac. Res. 37, 191-200. http://dx.doi.org/10.1016/j.cretres.2012.03.017.

Martinelli, A.G., Ribeiro, L.C.B., Mendez, A.H., Neto, F.M., Cavellani, C.L., Felix, E., Ferraz, M.L.D., Teixeira, V.D.A., 2013. Insight on the Theropod fauna from the Uberaba formation (Bauru group), Minas Gerais State: new Megaraptoran Specimen from the late Cretaceous of Brazil. Riv. Ital. Paleontol. Stratigr. 119 (2), 205-214.

Martinelli, A.G., Marinho, T.S., Filippi, L.S., Ribeiro, L.C.B., Ferraz, M.L.F., Cavellani, C.L., Teixeira, V.P.A., 2015. Cranial bones and atlas of titanosaurs (Dinosauria, Sauropoda) from late Cretaceous (Bauru group) of Uberaba, Minas Gerais State, Brazil. J. S. Am. Earth Sci. 61 (0), 164-170. http://dx.doi.org/10. 1016/j.jsames.2015.02.009.

Méndez, A.H., Novas, F.E., Iori, F.V., 2014. New record of Abelisauroid Theropods from the Bauru group (upper Cretaceous), São Paulo State, Brazil. Rev. Bras. Paleontol. 17 (1), 23-32. http://dx.doi.org/10.4072/rbp.2014.1.03.

Mezzalira, S., 1989. Os fósseis do Estado de São Paulo. Instituto Geológico, São Paulo.

Mezzalira, S., Simone, L.R.L., 1999. Duas novas espécies de Castalia (Mollusca, Bivalvia, Unionoida) no Cretáceo do Grupo Bauru, São Paulo, Brasil. Rev. Univ. Guarulhos - Geociênc. 4 (6), 58-60.

Morgan, R., 1978. Albian to Senonian Palynology of Site 364, Angola Basin. In: Bolli, H.M., Ryan, W.B.F., McKnight, B.K., Kagami, H., Melguen, M., Siesser, W.G., Natland, J.H., Longoria, J.F., Decima, F.P., Foresman, J.B., Hottman, W.E. (Eds.), Initial Reports of the Deep Sea Drilling Project. National Science Foundation, Washington.

Nascimento, P.M., Zaher, H., 2010. A new species of Baurusuchus (Crocodyliformes, Mesoeucrocodylia) from the Upper Cretaceous of Brazil, with the first complete postcranial skeleton described for the family Baurusuchidae. Papéis Avulsos Zool. 50 (21), 323-361.

Neumann, V.H., Borrego, A.G., Cabrera, L., Dino, R., 2003. Organic matter composition and distribution through the Aptian-Albian lacustrine sequences of the Araripe Basin, northeastern Brazil. Int. J. Coal Geol. 54, 21-40.

Nobre, P.H., Carvalho, I.S., 2006. Adamantinasuchus navae: a new Gondwanan Crocodylomorpha (Mesoeucrocodylia) from the late Cretaceous of Brazil. Gondwana Res. 10 (3-4), 370-378. http://dx.doi.org/10.1016/j.gr.2006.05.008.

Novas, F.E., Ribeiro, L.C.B., Carvalho, I.S., 2005. Rev. del Mus. Argent. Ciencias Nat. 7 (1), 31-36.

Ola-buraimo, A.O., Boboye, O.A., 2011. Palynological investigation of the Albian to lower Cenomanian Bima formation, Bornu Basin, Nigeria. World Appl. Sci. J. 12 (7), 1026-1033.

Olatunji, O.-B.A., 2013. Biostratigraphy and paleoenvironment of the Coniacian Awgu formation in Nzam-1 well, Anambra Basin, Southeastern Nigeria. Int. J. Sci. Technol. Res. 2 (3), 112-122.

Otero, O., Valentin, X., Garcia, G., 2008. Cretaceous Characiform Fishes (Teleostei: Ostariophysi) from Northern Tethys: Description of New Material from the Maastrichtian of Provence (Southern France) and Palaeobiogeographical
Implications. In: Geological Society, London, Special Publications, vol. 95 (1) pp. $155-164$.

Pinheiro, A.E.P., Bertini, R.J., Andrade, M.B., Martins Neto, R.G., 2008. A new Specimen of Stratiotosuchus maxhechti(Baurusuchidae, Crocodyliformes) from the Adamantina formation (upper Cretaceous), Southeastern Brazil. Rev. Bras. Pelontol. 11 (1), 37-50.

Poyato-Ariza, F.J., López-Horgue, M.A., García-Garmilla, F., 2000. A new early Cretaceous clupeomorph fish from the Arratia Valley, Basque Country, Spain. Cretac. Res. 21 (4), 571-585. http://dx.doi.org/10.1006/cres.2000.0212.

Prezzi, C.B., Götze, H.-J., Schmidt, S., 2014. Andean foreland evolution and flexure in NW Argentina: Chaco-Paraná Basin. Tectonophysics 628 (0), 228-243. http:// dx.doi.org/10.1016/j.tecto.2014.04.041.

Price, L.I., 1945. A new reptile from the Cretaceous of Brazil. Bol. do Dep. Nac Produção Miner. Notas Prelim. Estud. 25, 1-8.

Price, L.I., 1950. On a new Crododilia, Sphagesaurus, from the Cretaceous of the São Paulo State, Brazil. An. Acad. Bras. Ciências 22, 77-83.

Price, L.I., 1953. Bol. do Dep. Nac. Produção Miner. 147, 1-36.

Price, L.I., 1955. Novos Crocodilídeos dos Arenitos da Série Baurú, Cretáceo do Estado de Minas Gerais. An. Acad. Bras. Ciências 27 (4), 487-501.

Salgado, L., Carvalho, I.D., 2008. Uberabatitan ribeiroi, a new titanosaur from the Marilia formation (Bauru group, upper Cretaceous), Minas Gerais, Brazil. Palaeontology 51, 881-901. http://dx.doi.org/10.1111/j.1475-4983.2008.00781.x.

Santucci, R.M. 2008. First titanosaur (Saurischia, Sauropoda) axial remains from the Uberaba formation, upper Cretaceous, Bauru group, Brazil. Hist. Biol. 20 (3), 165-173. http://dx.doi.org/10.1080/08912960802461033.

Santucci, R.M., Bertini, R.J., 2006. A new titanosaur from western Sao Paulo State upper Cretaceous Bauru group, south-east Brazil. Palaeontology 49, 59-66. http://dx.doi.org/10.1111/j.1475-4983.2005.00527.x.

Sereno, P.C., Wilson, J.A., Conrad, J.L., 2004. New dinosaurs link southern land masses in the mid-Cretaceous. Proc. R. Soc. Lond. B 271 (1546), 1325-1330.

Sereno, P.C., Martinez, R.N., Wilson, J.A., Varricchio, D.J., Alcober, O.A., Larsson, H.C.E., 2008. Evidence for avian intrathoracic air sacs in a new predatory dinosaur from Argentina. PLoS One 3 (9), 1-20.

SIAGAS, Sistema de Informações de Águas Subterrâneas, n.d., Serviço Geológico do Brasil - SGB Companhia de Pesquisa de Recursos Minerais - CPRM.

Simone, L.R.L., Mezzalira, S., 1997. A posicao sistematica de alguns bivalves Unionoidea do Grupo Bauru (Cretaceo Superior) do Brasil. Rev. Univ. Guarulhos Geociênc. 2 (6), 63-65.

Suarez, J.M., 1969. Um quelônio da formação Bauru. In: 23th Congresso Brasileiro de Geologia, Salvador, Brasil.

Upchurch, P. Barret, P.M., Dodson, P. 2004. Sauropoda, In: Weishampel, D.B. Dodson, P., Osmolska, H. (Eds.), The Dinosauria. University of California Press, Berkeley, pp. 259-324.

Van Damme, D., Bogan, A.E., Dierick, M., 2015. A revision of the Mesozoic naiads (Unionoida) of Africa and the biogeographic implications. Earth Sci. Rev. 147, 141-200. http://dx.doi.org/10.1016/j.earscirev.2015.04.011.

Vullo, R., Marugan-Lobon, J., Kellner, A.W.A., Buscalioni, A.D., Gomez, B., de la Fuente, M., Moratalla, J.J., 2012. A new Crested Pterosaur from the early Cretaceous of Spain: the first European Tapejarid (Pterodactyloidea: Azhdarchoidea). PLoS One 7 (7). http://dx.doi.org/10.1371/journal.pone.0038900.

Wellnhofer, P., Buffetaut, E., 1999. Pterosaur remains from the Cretaceous of Morocco. Paläontol. Z. 73 (1) http://dx.doi.org/10.1007/BF02987987. 